\title{
DETERMINAÇÃO DE PARÂMETROS PARA A EQUAÇÃO UNIVERSAL DE PERDA DE SOLO NAS CONDIÇÕES DE SUMÉ-PB
}

\author{
ABEL WASHINGTHON DE ALBUQUERQUE
}

Engenheiro Agrônomo

Orientador: Dr. FRANCISCO LOMBARDI NETO

Tese apresentada à Escola Superior de Agricultura

"Luiz de Queiroz", Universidade de São Paulo, para a obtenção do título de Doutor em Agronomia, Área de Concentração: Solos e Nutrição de Plantas.

P I R A C I C A B A

Estado de São Paulo - Brasil

Setembro - 1997 
Dados Internacionais de Catalogaçāo na Publicação (CIP) DIVISÃO DE BIBLIOTECA E DOCUMENTACC̃O - Campus "Luiz de Queiroz"/USP

Albuquerque, Abel Washingthon de

Determinação de parâmetros para a equação universal de perda de solo nas condições de Sumé - PB / Abel Washingthon de Albuquerque. - Piracicaba, 1997.

133 p. : il.

Tese (doutorado) - Escola Superior de Agricultura Luiz de Queiroz, 1997.

Bibliografia.

1. Equação universal de perda de solo 2. Erosão 3. Paraiba 4. Região semiárida I. Título 


\title{
DETERMINAÇÃO DE PARÂMETROS PARA A EQUAÇÃO UNIVERSAL DE PERDA DE SOLO NAS CONDIÇÕES DE SUMÉ-PB
}

\author{
ABEL WASHINGTHON DE ALBUQUERQUE
}

Aprovada em: 10.11 .97

Comissão julgadora:

Prof. Dr. DÉCIO EUGÊNIO CRUCCIANI

ESALQ/USP

Prof. Dr. GERD SPAROVEC

ESALQ/USP

Dr. FRANCISCO LOMBARDI NETO

IAC

Dr ${ }^{\mathrm{a}}$ ISABELA CLERICI DE MARIA

IAC

Prof. $\mathrm{Dr}^{\mathrm{a}}$. MARLENE CRISTINA ALVES

FCA/UNESP

Dr. FRANCISEO LOMBARDI NETO

Orientador 


\begin{abstract}
A minha esposa Maria Cicera e aos meus filhos, Gustavo e Rizia, que nos momentos mais dificeis me deram a motivação necessária para a conclusão deste trabalho.
\end{abstract}

\title{
OFERE Ç O
}

A DEUS por manter em minha vida os sentimentos da esperança, perseverança e fé. 


\section{AGRADECIMENTOS}

Gostaria de expressar os meus mais sinceros agradecimentos as seguintes pessoas e instituições, que contribuíram para que este trabalho fosse realizado:

Ao Dr. Francisco Lombardi Neto, pelo apoio, incentivo e orientação, que foram de suma importância para a concretização deste trabalho.

Ao Profo Dr. Angêlo Catâneo pela recepção calorosa e pela orientação na análise estatística e computacional dos dados de chuva e solo.

Ao Departamento de Engenharia Civil, área de Recursos Hídricos da Universidade Federal da Paraíba (CCT/UFPB), Campus II, Campina Grande-PB, na pessoa do Prof. Dr. Vajapeyam S. Srinivasan, que gentilmente nos concedeu os dados da estação experimental de Sumé-PB.

Ao Prof. Dr. Carlos Galvão, que gentilmente nos auxiliou com preciosas informações, concernente ao experimento.

Ao corpo técnico da Universidade da Paraíba que esteve envolvido na execução do projeto.

A Escola Superior de Agricultura "Luiz de Queiroz" da Universidade de São Paulo pelos ensinamentos recebidos.

A Universidade Federal de Alagoas (UFAL) e ao Centro

de Ciências Agrárias (CECA) que me possibilitaram a oportunidade de concretizar o curso de Doutorado em Solos e Nutrição de Plantas.

Aos professores e ao corpo técnico da Pró-Reitoria de Pesquisa e Pós-Graduação (PROPEP/UFAL) pelo apoio dado.

A CAPES pelo apoio financeiro que nos concedeu, viabilizando economicamente a concretização da pós-graduação. 


\section{S U M Á R I O}

\section{Página}

RESUMO $\ldots \ldots \ldots \ldots \ldots \ldots \ldots \ldots \ldots \ldots \ldots \ldots \ldots \ldots \ldots \ldots \ldots \ldots \ldots$

SUMMARY $\ldots \ldots \ldots \ldots \ldots \ldots \ldots \ldots \ldots \ldots \ldots \ldots \ldots \ldots \ldots \ldots$

1 INTRODUÇÃo $\ldots \ldots \ldots \ldots \ldots \ldots \ldots \ldots \ldots \ldots \ldots \ldots \ldots$

2 REVISÃO DE IITERATURA ............... 5

2.1 A equação universal de perdas de solo (EUPS) $\ldots \ldots \ldots \ldots \ldots \ldots \ldots \ldots \ldots \ldots \ldots \ldots \ldots \ldots \ldots \ldots \ldots$

2.2 Parâmetros erosividade da chuva e a sua relação com as perdas de terra ......... 6

2.2.1 Volume total de chuva (Vr) .......... 7

2.2.2 Intensidades máximas (In) $\ldots \ldots \ldots \ldots \ldots \ldots 7$

2.2.3 Energia cinética: Ec, EcW, Ec>10 e Ec>25 8

2.2.4 Produto da energia cinética total pelas intensidades máximas $\left(E I_{n}\right) \ldots \ldots \ldots \ldots \ldots$

2.2.5 Produto do volume de chuva pelas intensidades máximas $\left(\mathrm{Vr} . \mathrm{I}_{\mathrm{n}}\right) \ldots \ldots \ldots$

2.3 Parâmetros erosividade da chuva, da enxurrada e da chuva-enxurrada ........... 14

2.4 Fator erodibilidade do solo (Fator K)...... 24 
Página

2.5 O desmatamento do semi-árido do Nordeste do

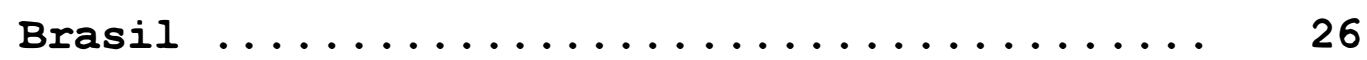

2.6 o efeito do manejo do solo sobre as perdas por erosão $\ldots \ldots \ldots \ldots \ldots \ldots \ldots \ldots \ldots \ldots \ldots \ldots$

3 MATERIAL E MÉTOdOS ................. 37

3.1 Localização da área experimental ........ 37

3.2 Descrição do clima ................ 37

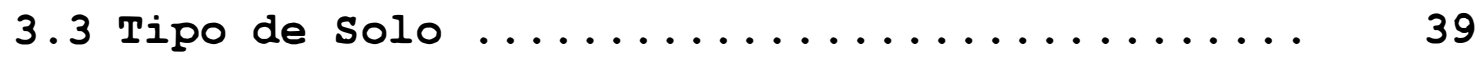

3.4 Geologia ........................ 39

3.5 A cobertura vegetal e o uso atual ........ 40

3.6 Pluviógrafo e pluviômetros ........... 40

3.7 Descrição da estação experimental de Sumé-PB ................... 41

3.7.1 Descrição das microbacias experimentais .. 41

3.7.2 Descrição das parcelas experimentais ..... 43

3.8 Critérios utilizados para separar chuvas erosivas $\ldots \ldots \ldots \ldots \ldots \ldots \ldots \ldots \ldots .46$

3.9 Determinação dos segmentos de intensidade uniforme das chuvas erosivas ...........

3.10 Digitalização dos pontos de inflexão da intensidade da chuva .............. 
Página

3.11 Determinação dos parâmetros erosividade da chuva e da enxurrada ...............

3.11.1 Energia cinética total (Ec e EcW) ......

3.11.2 Energia cinética de segmentos de chuva com intensidade constante igual ou maior do que 10 e $25 \mathrm{~mm} / \mathrm{h} \quad$ (Ec>10; $E C W>10 ; E C>25$ e ECW $>25) \ldots \ldots \ldots \ldots \ldots$

3.11.3 Produto da energia cinética total pelas intensidades máximas ( $E I_{n}$ e $\left.E W I_{n}\right)$.

3.11.4 Produto do volume de chuva pelas intensidades máximas $\left(V_{r} I_{n}\right) \ldots \ldots \ldots \ldots$

3.11 .5 Volume de enxurrada $\left(v_{u}\right) \ldots \ldots \ldots \ldots$

3.12 Correção das perdas de terra para as condições da parcela padrão ...........

3.13 Determinação das perdas de terra e água das microbacias experimentais ......

3.14 Determinação das perdas de terra e água das parcelas experimentais ....

3.15 Manejo das microbacias e parcelas experimentais .................. 
Página

3.16 Análise estatística dos parâmetros erosividade da chuva versus as perdas de terra $\ldots \ldots \ldots \ldots \ldots \ldots \ldots \ldots \ldots \ldots \ldots \ldots \ldots \ldots \ldots$

3.17 Determinação dos parâmetros erosividade da chuva, da enxurrada e da chuva-enxurrada.

3.18 Análise estatística dos parâmetros erosividade da chuva, da enxurrada e da chuva-enxurrada versus as perda de terra $\ldots \ldots \ldots \ldots \ldots \ldots \ldots \ldots \ldots \ldots \ldots \ldots \ldots \ldots \ldots \ldots \ldots \ldots$

3.19 Determinação do fator erodibilidade do solo

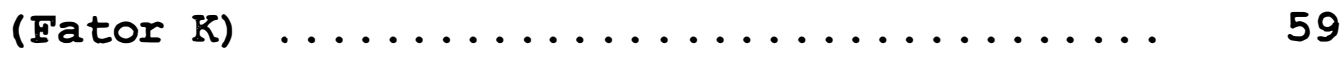

4 RESULTADOS E DISCUSSÃO .................. 60

4.1 Análise de regressão entre os parâmetros erosividade da chuva e as perdas de terra. 60

4.1 .1 volume de chuva $(V r) \ldots \ldots . \ldots \ldots$

4.1 .2 Intensidades máximas $\left(I_{n}\right) \ldots \ldots \ldots \ldots \ldots$

4.1.3 Energia cinética: Ec, EcW, Ec>10, $E C W>10, E c>25$ e $E C W>25 \ldots \ldots \ldots$

4.1.4 Produto do volume de chuva pelas intensidades máximas $\left(V_{I} \cdot I_{n}\right) \ldots \ldots \ldots \ldots$ 
Página

4.1.5 Produto da energia cinética pelas intensidades máximas $\left(E I_{n}\right.$ e $\left.\operatorname{EWI}_{n}\right) \ldots 69$

4.1.6 Análise do teste de homogeneidade ........ 70

4.2 Análise de regressão entre parâmetros erosividade da chuva, da enxurrada e da chuva-enxurrada versus as perdas de solo.... 72

4.2.1 Parâmetros erosividade da chuva ......... 74

4.2.2 Parâmetros erosividade da enxurrada....... 76

4.2.3 Parainetros erosividade da chuva-enxurrada ..... 78

4.2.3.1 Equações de regressão não linear (linear por anamorfose) ........... 79

4.2.3.2 Equações de regressão linear simples e linear múltiplas .......... 81

4.3 Distribuição da erosividade e da precipitação pluviométrica de sumé-PB....... 83

4.4 Fator erodibilidade do solo (Fator K) ...... 87

4.5 Análise das perdas de terra e água das parcelas experimentais ................ 90

4.5.1 Efeito do desmatamento e do manejo do solo sobre as perdas de terra ............... 90

4.5.2. Efeito do desmatamento e do manejo do solo sobre as perdas de água .............. 96 
Página

4.6 Análise das perdas de terra e água das

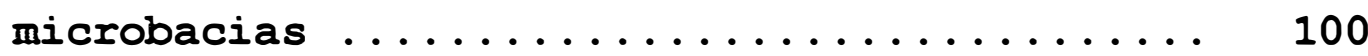

4.6.1. Análise das perdas de terra ........... 100

4.6.2 Análise das perdas de água ............ 102

4.7 Considerações finais .................. 104

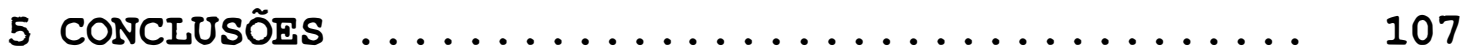

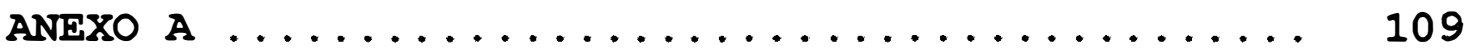

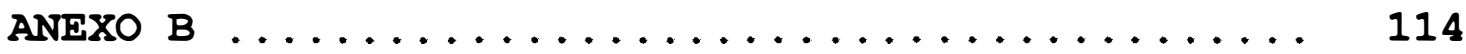

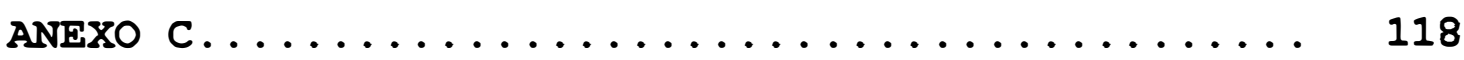

REETRÊNCIAS BIBLIOGRÁFICAS .............. 124 


\title{
DETERMINAÇÃO DE PARÂMETROS PARA A EQUAÇÃO UNIVERSAL DE PERDA DE SOLO NAS CONDIÇÕES DE SUMÉ-PB
}

\author{
Autor: ABEL WASHINGTHON DE ALBUQUERQUE \\ Orientador: Dr. FRANCISCO LOMBARDI NETO
}

\section{RESUMO}

Foram analisados dados de perda de terra e água por erosão sob condições de chuva natural no período de 1983 a 1990. Os dados foram obtidos de um solo Bruno Não Cálcico Vértico na estação experimental de Sumé-PB, pertencente a Universidade Federal da Paraíba-PB. A estação experimental de Sumé-PB é constituída por uma estação meteorológica, quatro microbacias e nove parcelas experimentais.

Para o cálculo do fator " $R$ " da equação universal de perdas de solo foram analisadas 255 chuvas individuais, correspondentes ao período de 1983 a 1990, e assim classificadas: 155 chuvas erosivas e 100 chuvas não erosivas. Para as correlações entre as perdas de terra e os parâmetros erosividade da chuva, da enxurrada e da chuva-enxurrada, foram analisadas 136 chuvas individuais no período de 26.02 .86 a 19.10 .90 , e assim classificadas: 75 chuvas erosivas e 61 chuvas não erosivas conforme Wischmeier \& Smith (1978). 
A partir dos dados obtidos foram determinados parâmetros para a equação universal de perdas de solo nas condições de Sumé-PB. Para tanto, foram estudadas: a) as correlações lineares, lineares múltiplas e não lineares (lineares por anamorfose) entre os parâmetros erosividade da chuva, da enxurrada e da chuva-enxurrada e as perdas de terra provocadas por chuvas individuais erosivas, objetivando identificar os melhores estimadores do potencial erosivo das chuvas de Sumé-PB, b) o fator "R" da equação universal de perda de solo, c) o fator erodibilidade do solo Bruno Não Cálcico Vértico e d) os efeitos do desmatamento e do manejo do solo sobre as perdas de terra e água.

Foi constatado através de análise de regressão não linear, que os parâmetros erosividade da enxurrada e da chuva-enxurrada, $a\left(V_{u} \cdot \alpha \cdot \mid 30\right)^{b}, a\left(V_{u}\right)^{b}, a\left(V_{u} \cdot \alpha \cdot \mid 5\right)^{b}$ e $a(E \mid A)^{b}$, foram os que melhor se correlacionaram com as perdas de terra, quando comparado com os demais parâmetros erosividade.

Entre os parâmetros erosividade da chuva, o que melhor se correlacionou com as perdas de terra foi o parâmetro $\mathrm{Vrl}_{25}$, entretanto constatou-se não haver diferença estatística significativa entre os parâmetros $\mathrm{Vrl}_{25}$ e $\mathrm{El}_{30}$. Portanto, o parâmetro $\mathrm{El}_{30}$, comumente utilizado para o cálculo do fator $R$ da equação universal de perdas de solo no Brasil pode ser utilizado como estimador do potencial erosivo das chuvas de Sumé-PB.

O fator erodibilidade obtido para a solo Bruno Não Cálcico Vértico foi considerado baixo (0,010 t.ha.h/ha.MJ.mm).

As parcelas desmatadas foram as que apresentaram as maiores perdas de terra e água por erosão, contribuindo para um aumento significativo das perdas de terra e água.

As parcelas com vegetação nativa (caatinga) e cobertura morta foram as mais efetivas no controle das perdas de terra e água. As parcelas com vegetação nativa e cobertura morta, quando comparadas com as 
parcelas desmatadas reduziram as perdas de terra entre 98 e $99 \%$ e as perdas de água entre 71 e $76 \%$.

As perdas de terra e água aumentaram significativamente com o desmatamento das microbacias. As microbacias com vegetação nativa constituída pela caatinga, quando comparadas com as microbacias desmatadas, reduziram as perdas de terra em torno de $99 \%$ e as perdas de água entre 89 e $93 \%$. 


\title{
DETERMINATION OF PARAMETERS FOR THE UNIVERSAL SOIL LOSS EQUATION IN THE CONDITIONS OF SUMÉ-PB
}

\author{
Author: ABEL WASHINGTHON DE ALBUQUERQUE \\ Adviser: Dr.FRANCISCO LOMBARDI NETO
}

\section{SUMMARY}

Soil and water losses by erosion under conditions of natural rainfall during the period from 1983 to1990 were analyzed. The data were obtained in Luvisol Vertic in the Experimental Station of Sumé (State Paraíba -Brazil) Federal University Paraiba (UFPB). The Experimental Station of Sumé-PB, is constituted by one meteorological station, four watersheds and nine runoff plots.

A total of 255 individual rainfalls to calculate of the factor "R" of the universal soil loss equation, during the period from 1983 a1990, were separated and classified as follows: a) 155 individual erosive rainfalls and b) 100 non-erosive. A total of 136 individual rainfalls for the correlation study, during the period of 1986 to 1990 were separated and classified as follows: 75 individual erosive rainfalls and b) 61 non-erosive, according to Wischmeier \& Smith (1978).

Using these data parameters were determined for the universal soil loss equation in the conditions of Sumé-PB. Therefore, a) linear, multiple linear and non-linear correlations among rainfall, runoff and rainfallrunoff erosivity parameters and the soil losses by erosion, aiming to identify the best estimates of the rainfall erosive potential in Sumé-PB, b) the factor " $R$ " of 
the universal soil loss equation, c) the erodibility factor and c) the effects of deforestation, mulch and management of the soil on the soil and water losses, were studied.

It was verified through non-linear regression analysis, that the erosivity parameters runoff and rainfall-runoff $\left(V_{u} \cdot \alpha \cdot 130\right)^{b},\left(V_{u}\right)^{b}$, $\left(V_{u} \cdot \alpha .15\right)^{b}$ and $(E I A)^{b}$, were the best correlated with the soil losses.

Among the rainfall erosivity parameters, $\mathrm{Vrl}_{25}$ was the one which best correlated with the soil losses, however, no significant statistical difference was found between the parameters $\mathrm{Vrl}_{25}$ e $\mathrm{El}_{30}$; therefore, the parameter $\mathrm{El}_{30}$, commonly used to calculate the factor " $\mathrm{R}$ " of the universal soil loss equation in Brazil, can be used to estimate the erosive potential of the rainfall in Sumé-PB.

The erodibility factor estimated for the Vertic Luvisol was considered low (0,010 t.ha.h/ha.h).

The experimental runoff plots, where the deforestation has occurred, presented the highest soil and water losses by erosion, contributing to a significant increase in the soil and water losses by erosion.

The runoff plots with native vegetation (caatinga) and mulch were the most effective to control the soil and water losses. Compared with the deforested runoff plots, those with native vegetation and mulch, reduced the soil losses within 98.6 and $99.7 \%$ and the of water losses within 71 and $76 \%$.

The soil and water losses increased significantly in the deforested watersheds. The watersheds with native vegetation (caatinga), as compared to deforested watersheds, contributed to reduce the soil losses within 99.4 and $99.6 \%$ and the of water losses within 89.3 and $93.0 \%$. 


\section{INTRODUÇÃO}

A iniciativa de se estudar uma microbacia experimental dentro do contexto edafoclimático da microbacia de Sumé-PB, surgiu a partir do Programa de Bacias Representativas do Nordeste Brasileiro, desenvolvido pela Superintendência do Desenvolvimento do Nordeste (SUDENE) no final do ano de 1980. O referido programa teve o financiamento do Conselho Nacional de Desenvolvimento Científico e Tecnológico (CNPq), que nos meados do ano de 1980, estabeleceu uma linha de financiamento para realização de estudos em bacias experimentais, solicitando na ocasião ao Setor de Bacias Representativas da SUDENE projetos neste sentido.

A Bacia Representativa de Sumé-PB, com $137,4 \mathrm{~km}^{2}$, é constituída por 3 sub-bacias a saber: Gangorra, Jatobá e Umburana, sendo que a sub-bacia de Umburana, de $10,7 \mathrm{~km}^{2}$, foi o local escolhido para a instalação da estação experimental de Sumé.

A pressão demográfica no semi-árido do Nordeste do Brasil tem contribuído para uma crescente demanda de produtos agrícolas e florestais, exigindo um incremento rápido da produção agrícola. Entretanto, este incremento tem sido feito as custas do desmatamento indiscriminado da caatinga.

A caatinga do Nordeste do Brasil, tem uma complexa formação de vegetais xerófilas e apresenta um equilíbrio ecológico instável. Esse equilíbrio instável, criado pelas condições de clima e solo, permite aos seres vivos que habitam essa faixa, principalmente a cobertura vegetal que a 
reveste, apenas uma existência precária, com imenso esforço de adaptação e sobrevivência. Esse equilíbrio instável próprio de climas semi-áridos, foi o criador dos grandes desertos. A ocorrência de secas prolongadas quando associadas a uma intervenção inamistosa do homem, através do desmatamento indiscriminado (para a formação de novos campos agrícolas, coleta de madeira para construções, cercas, lenha e carvão), queimadas sucessivas e manejo inadequado do solo e da flora, tem comprometido o seu frágil equilíbrio ecológico.

O atendimento das necessidades de lenha e carvão para um estado nordestino como o Ceará, implicaria no desmatamento anual de uma área equivalente a 100.000 ha. Considerando o caráter extrativista da exploração de madeira na caatinga, não é difícil se prever o esgotamento das reservas florestais da caatinga para as próximas décadas (Araújo Filho \& Carvalho, 1996).

Assim, a destruição da caatinga na região semi-árida do Nordeste do Brasil tem contribuído para acelerar a erosão do solo, trazendo como conseqüências, o empobrecimento dos solos, o assoreamento dos rios e dos açudes públicos e privados. Portanto, a fragilidade do ecossistema do semi-árido do Nordeste do Brasil, quando associada ao desmatamento, às condições climáticas adversas, à pressão demográfica e a uma agricultura itinerante e sem práticas conservacionistas, tem resultado num aumento significativo das áreas de risco de degradação nesta região.

A erosão é um fenômeno cujo impacto sobre os recursos naturais, tem preocupado governos e instituições em todo o mundo. $A$ magnitude deste fenômeno, tem sido considerada como uma ameaça a própria existência da humanidade. Esta ameaça tem contribuído, para que haja uma imperiosa necessidade de se controlar de forma racional, as diversas formas de erosão. 
A erosão hídrica depende de vários fatores tais como: clima, solo, vegetação e atividades humana, sendo que a mesma se manifesta de várias formas em função da amplitude de variação desses fatores, cujo conhecimento pode orientar as medidas mais adequadas de conservação e manejo do solo.

A necessidade de determinar-se uma metodologia capaz de avaliar com precisão, os fatores que causam a erosão e a estimativa das perdas de solo causada pela mesma, tem resultado em intensas pesquisas. Dentre as metodologias pesquisadas, a equação universal de perdas de solo (EUPS) tem sido uma das mais utilizadas, visto que inclui todos os fatores que influenciam a erosão hídrica, além de permitir a previsão das perdas de terra causadas pela erosão e indicar quais são os fatores que exercem os maiores efeitos sobre as perdas de terra (Wischmeier \& Smith, 1978).

No planejamento conservacionista a EUPS é comumente utilizada, principalmente com o objetivo de manter a produtividade agrícola. A estimativa das perdas médias de solo, que poderão ocorrer em determinadas atividades agrícolas, poderá atender satisfatoriamente a este objetivo. Entretanto em planejamento de obras onde as perdas de solo estimadas são necessárias para chuvas individuais, a estimativa da EUPS pode diferir grandemente dos dados observados. Estudos de princípios básicos de mecânica de erosão, concluíram que uma estimativa mais precisa das perdas de solo para para chuvas individuais, requer a combinação de um parâmetro erosividade da enxurrada com um parâmetro erosividade da chuva da EUPS. Portanto, a estimativa de perdas de solo para uma chuva indivuidual, poderia ser significativamente melhorada com a adição de um parâmetro erosividade da enxurrada ao parâmetro erosividade da chuva da EUPS (Foster et al., 1977b). 
A determinação de parâmetros para a equação universal de perdas de solo nas condições do semi-árido do Nordeste do Brasil, contribuirá para que se tenha um modelo de previsão das perdas de solo mais preciso, de forma que o planejamento do uso e manejo dos solos da região possa ser estabelecido com maior confiabilidade.

Pretende-se com 0 presente trabalho atingir os seguintes objetivos:

1) determinar os parâmetros erosividade da chuva, da enxurrada e chuva-enxurrada, que melhor se ajustem as condições climáticas de Sumé-PB, a partir de correlações com as perdas de solo, causadas por chuvas erosivas.

2) determinar o fator erosividade da chuva da equação universal de perdas de solo.

3) determinar o fator erodibilidade do solo em estudo.

4) quantificar as perdas por erosão sob vegetação natural e após as modificações causadas pelo desmatamento e cultivo. 


\section{REVISÃO DE LITERATURA}

\subsection{A equação universal de perda de solo (EUPS).}

A equação universal de perda de solo (EUPS) como atualmente tem sido utilizada, foi desenvolvida a partir de 1953, quando o Soil and Water Conservation Research Division of the Agricultural Research Service, reuniu na Universidade de Purdue (E.U.A), dados de escoamento superficial e de perdas de solo de 10.000 parcelas de 48 estações experimentais dos E.U.A (Wischmeier \& Smith, 1978). Com base nestes dados, foram incluídas inovações importantes que melhoraram a precisão da estimativa de perdas de solo quais sejam: um índice de erosividade da chuva, um método para avaliação dos efeitos do manejo de uma cultura, um método para quantificar a erodibilidade do solo e um método para determinar os efeitos das interações de variáveis tais como: produtividade, seqüência de culturas e manejo dos resíduos culturais (Wischmeier \& Smith, 1978).

Com as inovações introduzidas, as dificuldades em se considerar fatores de natureza climática ou geográfica, existente nas primeiras equações foram superadas, permitindo sua aplicação em qualquer lugar onde os dados para o seu cálculo pudessem ser obtidos, sendo por isso chamada de equação universal de perda de solo.

A EUPS é constituída pelos principais fatores que causam a erosão hídrica, sendo que o produto de todos os fatores resultará na 
estimativa das perdas de solo em Mg/ha. A equação pode ser expressa matematicamente da seguinte forma:

$$
A=R \cdot K \cdot I . S . C . P
$$

Onde: "A" é a perda média anual de solo (Mg/ha/ano); "R" é o fator erosividade da chuva, expresso por um índice numérico, que estima a capacidade da chuva de provocar erosão (MJ.mm/ha.h); "K" é o fator erodibilidade do solo, sendo expresso numericamente pela relação entre a perda média anual de solo e o fator erosividade da chuva. Os dados de perda de solo são obtidos de uma parcela padrão, com as seguintes características: 9\% de declividade, 22,13 m de comprimento, mantida continuamente sem cobertura vegetal e cultivada morro abaixo, de forma a manter a superfície do solo livre de crostas (t.h/MJ.mm); "L" é o fator comprimento do declive, sendo expresso pela relação de perdas de solo entre uma encosta com um certo comprimento e outra com $22,13 \mathrm{~m}$, sendo as demais condições mantidas iguais; "S" é o fator grau de declive, sendo expresso pela relação de perdas de solo entre uma encosta com um certo declive e outra com $9 \%$ de declividade, sendo as demais condições mantidas iguais; " $C$ " é o fator uso e manejo do solo, sendo expresso pela relação de perdas de solo entre um solo cultivado com uma determinada cultura e manejo e um solo mantido constantemente sem cobertura, isto é, nas mesmas condições de avaliação do fator $K$; "P" é o fator prática conservacionista, sendo expresso pela relação de perdas de solo entre um solo com uma determinada prática de controle da erosão e um solo sem prática conservacionista.

\subsection{Parâmetros erosividade da chuva e sua relação com as perdas de terra}


Os parâmetros erosividade da chuva, utilizados para estimar a capacidade potencial da chuva de provocar erosão no semi-árido do Nordeste do Brasil, têm sido basicamente o $\mathrm{El}_{30}$ e o Ec>25 (Leprun, 1988).

Para as condições edafoclimáticas da região do Nordeste do Brasil, são escassos os trabalhos que estabelecem correlações entre parâmetros erosividade da chuva e perdas de solo, objetivando determinar quais os parâmetros da chuva, que poderiam estimar com maior precisão as perdas de solo causada pela erosão (Albuquerque, 1993).

\subsubsection{Volume total de chuva ( $\mathrm{Vr}$ )}

O volume total de chuva, é uma característica física da chuva, que por sua simplicidade e facilidade de obtenção, têm sido utilizado com freqüência nos estudos de correlações com as perdas de solo.

Para as condições edafoclimáticas de Campinas-SP, Mococa-SP e Pindorama-SP, Carvalho (1992) constatou que o volume total de chuva, apresentou em termos absolutos, coeficientes de correlação mais baixo ( $r=0,64$ a 0,49) do que parâmetros tais como: energia cinética $(r=0,71$ a $0,55), E c>10$ ( $r=0,77$ a 0,55$), E c>25$ ( $r=0,76$ a 0,57$)$ e $E_{30}(0,76$ a 0,60$)$. $O$ autor constatou também, haver diferença estatística significativa entre os coeficientes de correlação do volume total de chuva e os parâmetros acima citados.

Um baixo coeficiente de correlação $(r=0,32)$ foi obtido para a correlação entre o volume total de chuva e as perdas de solo de um Regossolo em Caruaru-PE (Albuquerque et al.,1994).

\subsubsection{Intensidades máximas (In)}

Assim como o volume de chuva, as intensidades máximas em tempos crescentes (In), são parâmetros básicos da chuva 
utilizados com muita freqüência nos trabalhos de correlação com as perdas de solo, apesar de geralmente apresentarem baixos coeficientes de correlação. Entretanto, quando em combinação com parâmetros tais como: o volume total de chuva e a energia cinética, tem contribuído para melhorar de forma significativa a correlação com as perdas de solo (Lombardi Neto, 1979, Foster et al., 1982, Carvalho, 1992 e Albuquerque et al., 1994).

Estudos de correlação, realizados por Albuquerque et al. (1994) resultaram na obtenção de baixos coeficientes de correlação, para as relações entre as intensidades máximas e as perdas de solo $(r=0,299$ a 0,542 ). O autores concluíram, que quando comparado com as demais intensidades para tempos menores, a intensidade máxima em 60 minutos, foi a que apresentou a melhor correlação com as perdas de solo em Caruaru-PE.

Carvalho et al. (1993) correlacionando parâmetros erosividade da chuva com as perdas de solo de Campinas -SP, obtiveram coeficientes de correlação ( $r$ ) de 0,604 e 0,599 para as intensidades máxima em trinta minutos (130) e sessenta minutos (160) respectivamente. Para Mococa-SP, foram obtidos para as respectivas intensidades, os seguintes coeficientes de correlação (r): 0,689 e 0,699 (Carvalho, 1992).

\subsubsection{Energia cinética: Ec, EWc, Ec>10 e Ec>25}

O estudo sobre a energia cinética da chuva, foi realizado através de um trabalho clássico desenvolvido por Wischmeier \& Smith (1958). Os autores acima mencionados, tomando como base os trabalhos de Laws \& Parsons (1943), estudaram as relações entre a intensidade, a distribuição do tamanho de gotas de chuva e a energia cinética. Em continuação ao seu estudo Wischmeier \& Smith (1958), passaram a estudar as relações entre a energia cinética e as perdas de solo, onde

obtiveram um alto coeficiente de determinação $\left(r^{2}=0,98\right)$. A equação para o 
cálculo da energia cinética expressa no Sistema Internacional de Unidades, segundo Foster et al. (1981) é a seguinte:

$$
\mathbf{E C}=0,119+0,0873 \log I, \ldots \ldots \ldots(2)
$$

onde: Ec é a energia cinética em $\mathrm{MJ} / \mathrm{ha} \cdot \mathrm{mm}$ e I é a intensidade em $\mathrm{mm} / \mathrm{h}$. Para $\mathrm{I}>76 \mathrm{~mm} / \mathrm{h}$, o valor máximo da energia cinética é igual a 0,2832

No Brasil um dos poucos estudos sobre a relação entre distribuição de tamanho de gotas de chuva, intensidade e energia cinética foi o desenvolvido por Wagner \& Massambani (1988). A partir de registros disdrométricos de distribuição do tamanho da gota de chuva, os autores estabeleceram análise de regressão entre a energia cinética e a intensidade de três chuvas convectivas de verão ocorridas em Bauru (SP), onde obtiveram um coeficiente de determinação $\left(r^{2}\right)$ de 0,60 para a equação de regressão abaixo descrita:

$$
\mathrm{ECW}=0,153+0,0645 \log \mathrm{I} \ldots \ldots \text { (3) }
$$

onde: EcW é a energia cinética da chuva (MJ/ha.mm) e I é a intensidade da chuva $(\mathrm{mm} / \mathrm{h})$.

Pesquisas sobre a relação entre a distribuição de gotas de chuva, intensidade e energia cinética para as condições fisiográficas de Londrina-PR, foram desenvolvidas por Roth et al. (1984). Os autores constataram que os diâmetros de gotas de chuva, foram em termos médios, maiores do que os obtidos em outros países e também no Nordeste do Brasil. Constataram também que a relação entre a energia cinética e a intensidade de chuvas convectivas, apresentava dados de energia cinética maiores que os estimados pela equação de Wischmeier \& Smith (1958). 
Trabalho de pesquisa, objetivando estudar as relações entre distribuição de tamanho de gotas, intensidade e energia cinética para dois locais do centro sul dos E.U.A, foram desenvolvidas por Carter et al. (1974). Os autores, obtiveram resultados que diferiram daqueles obtidos por Laws \& Parsons (1943). Estes autores constataram que a energia cinética aumentava com a intensidade até o intervalo de $50-75 \mathrm{~mm} / \mathrm{h}$, diminuindo até intensidades de 175 - $200 \mathrm{~mm} / \mathrm{h}$, onde começava a aumentar novamente com o aumento da intensidade.

Deve-se ressaltar que os dados de Laws \& Parsons (1943), foram extrapolados com o objetivo de obter-se valores para a distribuição de gotas para intensidades de 100 a $150 \mathrm{~mm} / \mathrm{h}$. Por outro lado, Wischmeier \& Smith (1958), também extrapolaram os mesmos dados, ainda mais, com o objetivo de calcular a energia cinética da chuva para intensidades de até $250 \mathrm{~mm} / \mathrm{h}$, resultando por conseguinte numa superestimativa da energia cinética para chuvas de alta intensidade.

Um índice de erosividade baseado na hipótese de que deveria haver um valor crítico de intensidade de chuva, a partir do qual as perdas de solo começavam a ser significativas foi desenvolvido por Hudson (1981). O autor verificou que a energia cinética de segmentos de intensidades iguais ou superiores a $25,4 \mathrm{~mm} / \mathrm{h}$, apresentaram maiores correlações com as perdas de solo, do que qualquer outro parâmetro da chuva quando considerado isoladamente. O parâmetro desenvolvido foi denominado de $\mathrm{KE}>25$.

Para três locais do Rio Grande do Sul, Morais (1986) correlacionou parâmetros erosividade da chuva com perdas de solo, onde observou, que a energia cinética quando correlacionada com as perdas de solo, obteve os seguintes coeficientes de correlação: $r=0,57$ em ljuí, $r=0,66$ em Santa Maria e $r=0,72$ em Guaíba respectivamente. $O$ autor constatou 
também que o parâmetro erosividade da chuva, que melhor se correlacionou com as perdas de solo em Guaíba, foi o $\mathrm{Ec}>10(r=0,78)$.

Correlações entre diversos parâmetros erosividade da chuva e as perdas de solo de Campinas-SP, Mococa-SP e Pindorama-SP, foram estabelecidas por Carvalho (1992). O autor constatou que os parâmetros erosividade da chuva Ec>10 e Ec>25 apresentaram para as respectivas localidades, os seguintes coeficientes de correlação: $r=0,69$ e 0,$67 ; r=0,77$ e 0,76 e $r=0,55$ e 0,57 respectivamente. $O$ autor constatou também não existir diferença estatística entre os coeficientes de correlações dos seguintes parâmetros entre si: $\mathrm{El}_{30}$ e Ec>10, $\mathrm{El}_{30}$ e Ec>25. O autor concluiu, que o parâmetro erosividade da chuva que melhor estimou as perdas de solo de Campinas e Mococa foi o parâmetro Ec>10.

Albuquerque et al. (1994) obtiveram para os parâmetros erosividade da chuva Ec>10 e Ec>25 respectivamente, os seguintes coeficientes de correlação: $r=0,52$ e 0,56. O autor concluiu, que a eliminação dos valores da energia cinética das intensidades inferiores a 10 e $25 \mathrm{~mm} / \mathrm{h}$ respectivamente, melhorou a estimativa das perdas de solo, uma vez que, os valores dos coeficientes de correlação dos parâmetros Ec>10 e Ec>25, foram maiores do que o obtido para a energia cinética total.

\subsubsection{Produto da energia cinética total pelas intensidades máximas (Eln)}

O parâmetro erosividade da chuva $\mathrm{El}_{30}$, foi estabelecido num trabalho desenvolvido por Wischmeier \& Smith (1958). Os autores pesquisando a relações entre os parâmetros erosividade da chuva e as perdas de solo nos E.U.A, com o objetivo de estabelecer um parâmetro erosividade, que melhor estimasse a capacidade da chuva de provocar erosão, verificaram que as perdas de solo provocadas por chuvas erosivas, 
apresentaram uma elevada correlação com o produto entre dois parâmetros da chuva a saber: energia cinética total e intensidade máxima em 30 minutos. 0 referido produto foi denominado como índice de erosividade $\mathrm{El} 30$. Estatisticamente o parâmetro El30 foi capaz de explicar entre 72 a $97 \%$ das perdas de solo causado por chuvas erosivas.

Correlações linear simples entre parâmetros erosividade da chuva e perdas de solo de três diferentes locais do Rio Grande do Sul: Guaíba, ljuí e Santa Maria, foram realizadas por Morais (1986). Os dados obtidos possibilitaram as seguintes conclusões: a) cada local apresentou um parâmetro erosividade da chuva diferente, que melhor se correlacionou com as perdas de solo. b) para ljuí e Santa Maria os parâmetros que melhor se correlacionaram com as perdas de solo foram os parâmetros $\mathrm{El}_{10}$ e $\mathrm{El}_{5}(\mathrm{r}=$ $0,76$ e 0,78$)$ b) para todos os locais estudados, o parâmetro $\mathrm{El}_{25}(r=0,65)$ foi o que apresentou a melhor correlação.

Carvalho (1992) correlacionando parâmetros da erosividade da chuva com as perdas de solo ocorridas em Campinas-SP, Mococa-SP e Pindorama-SP, constatou que o parâmetro $\mathrm{El}_{30}$ apresentou em termos absolutos coeficientes de correlação semelhantes $(r=0,67,076$ e 0,60) aos dos seguintes parâmetros: energia cinética total $(r=0,67,0,71$ e 0,53$)$, $E c>10(r=0,69,0,77$ e 0,55) e Ec>25 (0,67, 0,76 e 0,57). O autor constatou também não haver diferença estatística significativa entre os coeficientes de correlação do parâmetro $\mathrm{El}_{30}$ e os parâmetros acima citados.

Catalince \& Margolis (1994) correlacionaram parâmetros erosividade da chuva com perdas de solo em Glória de Goitá-PE. Para o parâmetro $\mathrm{El}_{30}$ obtiveram coeficientes de correlação $(r)$ de 0,73 , enquanto que para o parâmetro Ec>25 obtiveram um coeficiente de correlação ( $r$ ) de 0,63 . Os autores concluíram afirmando que não constataram diferença estatística entre os parâmetros $\mathrm{El}_{30}$ e Ec>25 respectivamente. 
Albuquerque et al. (1994) constataram que os parâmetros da chuva $E I_{n}$, quando correlacionados com as perdas de solo em Caruaru-PE, apresentaram coeficientes de correlação que variaram de $r=0,46$ a 0,66 , para os parâmetros $\mathrm{El}_{15}$ e $\mathrm{El}_{60}$ respectivamente. Os autores constataram também, que não houve diferença estatística entre os parâmetros $\mathrm{El}_{30}$ e $\mathrm{Vr} / 30$.

\subsubsection{Produto do volume de chuva pelas intensidades máximas (Vr.In)}

Vários pesquisadores tem incluído o parâmetro Vrln nos estudos de correlação com as perdas de solo por vários razões, entre as quais destacam-se as seguintes: simplicidade, praticidade, e finalmente, pelo fato de dispensar o cálculo da energia cinética da chuva (Lombardi Neto, 1979, Foster et al., 1982, Carvalho, 1992 e Albuquerque et al., 1994)

Carvalho (1992), correlacionando o produto do volume de chuva pela intensidade máxima em 30 minutos com as perdas de solo de Campinas-SP, Mococa-SP, e Pindorama-SP, obteve baixos coeficientes de correlação $(r=0,47,0,57$ e 0,36).

Os valores dos coeficientes de correlação do parâmetro erosividade da chuva $\mathrm{V}_{\mathrm{r}} \mathrm{l} 30$ ( $r=0,511$ a 0,895 ), obtidos para 10 localidades dos E.U.A, quando comparado com os valores dos parâmetros erosividade da enxurrada ( $r=0,381$ a 0,876), apresentou em seis localidades, maiores valores do coeficiente de correlação (Lombardi Neto, 1979 e Foster et al., 1982).

Estudos de correlações, envolvendo os parâmetros erosividade $\mathrm{V}_{\mathrm{r}} \mathrm{30}$ e as perdas de solo ocorridas em Caruaru-PE, foram desenvolvidos por Albuquerque et al. (1994). Os autores constataram que o produto do volume total de chuva pela intensidade máxima em 30 minutos $\left(\mathrm{V}_{\mathrm{r}} / 30\right)$ foi o parâmetro erosividade que melhor se correlacionou com as perdas 
de solo, entretanto constataram não haver diferença estatística em relação ao parâmetro $\mathrm{E}_{30}$.

\subsection{Parâmetros erosividade da chuva, da enxurrada e da chuva-enxurrada}

Estudos de princípios básicos envolvidos no processo erosivo, sugere que uma precisa estimativa das perdas de solo para eventos específicos, requer a combinação de um parâmetro erosividade da enxurrada com um parâmetro erosividade da chuva da EUPS. A justificativa para a introdução de um parâmetro erosividade da enxurrada, resulta do fato que o parâmetro erosividade $\mathrm{El}_{30}$, é calculado inteiramente de parâmetros físicos da chuva, portanto não refletindo o efeito da enxurrada. Assim, a predição de perdas de solo para uma chuva individuais erosivas, pode ser estimada com maior precisão através da adição de um parâmetro erosividade da enxurrada ao parâmetro erosividade da chuva da EUPS (Foster et al., 1977b).

Inúmeros parâmetros erosividade da chuva, da enxurrada e chuva-enxurrada, têm sido expressos por equações lineares simples, lineares múltiplas e não lineares, na tentativa de se encontrar parâmetros que estimem com a maior precisão possivel as perdas de solo causadas por chuvas erosivas. Muito desses parâmetros foram desenvolvidos a partir de equações empíricas, portanto, nesta parte da revisão bibliográfica, serão abordados os parâmetros mais utilizados nos trabalhos que tratam deste assunto (Lombardi Neto, 1979; Foster et al., 1982 e Carvalho, 1992)

Lombardi Neto (1979) assumiu a premissa de que a chuva e a enxurrada poderiam ser expressas por duas constantes a saber: intensidade da chuva $\left(I_{30}\right)$ e a taxa do pico de descarga da enxurrada $\left(\sigma_{\mathrm{pu}}\right)$. A partir dessa premissa, o autor estabeleceu as seguintes relações matemáticas concernentes a chuva e a enxurrada: 


$$
\sigma_{\mathrm{pu}} / I_{30}=\mathrm{D} / \mathrm{T}=\alpha \ldots \ldots
$$

Onde: $\alpha$ é um termo de proporcionalidade entre a enxurrada e a chuva; $D$ é o tempo de duração da enxurrada; $T$ é o tempo de duração da chuva; I30 é a intensidade máxima em 30 minutos e $\sigma_{p u}$ é a taxa do pico da enxurrada $(\mathrm{mm} / \mathrm{h})$.

$$
\begin{gathered}
\text { Como: } \sigma_{\mathrm{Pu}} / I_{30}=\alpha \\
\mathrm{D} / \mathrm{T}=\alpha,
\end{gathered}
$$

Por conseguinte:

$$
\begin{aligned}
& D=\alpha . T \ldots \ldots \ldots \ldots \ldots \ldots \\
& \sigma_{p u}=\alpha . I_{30} \ldots \ldots \ldots \ldots
\end{aligned}
$$

Como o volume da enxurrada $\left(V_{\mathrm{U}}\right)$ pode ser expresso pela equação (7):

$$
\mathrm{v}_{\mathrm{u}}=\sigma_{\mathrm{pu}} \cdot \mathrm{D} \ldots \ldots \ldots \ldots
$$

Então, substituindo-se as equações (5) e (6) na equação (7), pode-se deduzir que:

$$
v_{u}=\alpha^{2} \cdot I_{30} \cdot T \ldots \ldots
$$

Considerando, que o volume da chuva $\left(\mathbf{V}_{\mathbf{r}}\right)$ é igual ao produto de sua intensidade $\left(I_{30}\right)$ pela sua duração.

$$
v_{r}=I_{30} \cdot T \ldots \ldots \ldots \ldots
$$


Então, substituindo-se a equação (9) na equação (8), pode deduzir-se que:

$$
v_{u}=\alpha^{2} \cdot v_{r} \ldots \ldots \ldots
$$

Por conseguinte, tem-se que:

$$
\alpha=\left(v_{u} / v_{r}\right)^{1 / 2} \ldots \ldots \ldots \ldots .
$$

O termo dado pela equação (11), foi utilizado em combinação com inúmeros parâmetros erosividade da chuva-enxurrada propostos por Lombardi Neto (1979); Foster et al. (1982) e Carvalho (1992).

Modelos matemáticos desenvolvidos para estimar as perdas de solo causada pela chuva nos entresulcos, possibilitaram concluir que estas perdas são proporcionais ao quadrado de sua intensidade. Com base nesta premissa foi proposta a seguinte equação (Meyer \& Wischmeier, 1969 e Foster \& Meyer, 1975):

$$
E I A=I^{2} 30 \cdot D \ldots \ldots \ldots
$$

Onde: EIA é o parâmetro erosividade da chuvaenxurrada para o tempo da enxurrada; $I_{30}$ é a intensidade máxima em 30 minutos e D é o tempo de duração da enxurrada.

A diferença entre os parâmetros $\mathrm{El}_{30}$ e EIA, é relativa a duração na qual o I30 proporciona as perdas de solo. Em relação ao parâmetro El30, a duração é aquela referente ao tempo total da chuva $(T)$, sendo que no caso do EIA, é aquela referente ao tempo total da enxurrada (D). Portanto, o parâmetro EIA estima as perdas de solo apenas quando ocorre enxurrada, 
enquanto que o El30 estima as perdas de solo na presença ou não da enxurrada (Lombardi Neto, 1979 e Foster et al., 1982).

Considerando o fato de que a duração da enxurrada (D), não foi mensurada em parcelas experimentais, a mesma deduzida, através da seguinte forma (Lombardi Neto, 1979):

$$
\begin{aligned}
& \operatorname{Vr}=\mathrm{I}_{30} \cdot \mathrm{T}, \\
& \text { então; } \\
& \quad \mathrm{T}=\mathrm{Vr} / \mathrm{I}_{30} \ldots \ldots \ldots \ldots \ldots
\end{aligned}
$$

Substituindo-se a equação (5) na equação (12); a equação (11) na (14) e a equação (13) na equação (15), tem-se que:

$$
\begin{aligned}
& E I A=I^{2} 30 \cdot D \ldots \ldots \ldots \ldots \ldots \\
& E I A=I^{2} 30 \cdot \alpha \cdot T \ldots \ldots \ldots \\
& E I A=I^{2} 30 \cdot\left(V_{u} / V_{r}\right)^{1 / 2} \cdot \ldots \ldots \ldots \\
& E I A=I^{2} 30 \cdot\left(V_{u} / V_{r}\right)^{1 / 2} \cdot V_{r} / I_{30}
\end{aligned}
$$

Por conseguinte, deduz-se que:

$$
E I A=I_{30} \cdot\left(V_{u} \cdot V_{r}\right)^{1 / 2} \ldots \ldots \ldots
$$

Onde: EIA é o parâmetro erosividade da chuvaenxurrada para o tempo da enxurrada $\left(\mathrm{mm}^{2} / \mathrm{h}\right) ; I_{30}$ é a intensidade máxima em 30 minutos; $D$ é o tempo de duração da enxurrada, $V r$ é o volume de chuva $(\mathrm{mm})$ e $V_{\mathrm{u}}$ é o volume de enxurrada; $\alpha=\left(V_{\mathrm{u}} N_{\mathrm{r}}\right)^{1 / 2}$ (adimensional).

Considerando o fato de que o parâmetro erosividade da chuva do tipo El, apresenta um certo grau de complexidade, é que Foster et al. 
(1982) introduziram alguns parâmetros, objetivando simplificar a obtenção de um parâmetro erosividade da chuva, em que não houvesse a necessidade de se calcular a energia cinética e que apresentassem uma estimativa das perdas de solo, semelhante aquela obtida pelo parâmetro El. Os modelos propostos foram os seguintes:

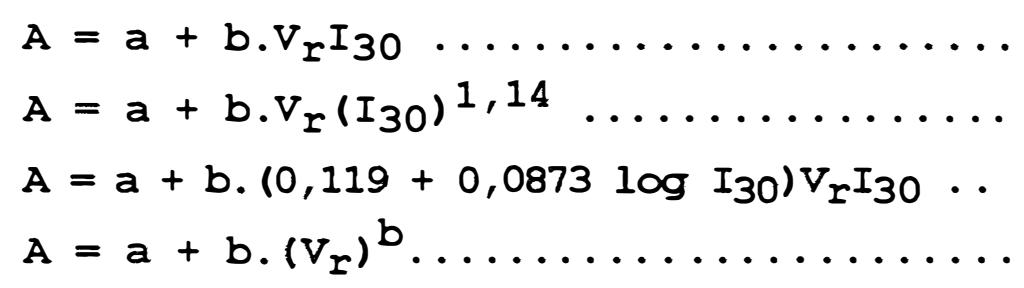

Onde: $A$ é a estimativa de perda de solo em $\mathrm{Mg} / \mathrm{ha} ; \mathrm{V}_{\mathrm{r}}$ é o volume de chuva, 130 é a intensidade máxima em 30 minutos e a e b são os coeficientes de regressão a serem ajustados.

Objetivando obter a combinação de um parâmetro erosividade da chuva-enxurrada (EIA) com um parâmetro erosividade da chuva (El30), é que Lombardi Neto (1979) e Foster et al. (1982), propuseram o seguinte parâmetro erosividade da chuva-enxurrada expresso pela seguinte equação:

$$
A=a+b \cdot\left(E_{30}\right)+c \cdot E I A \ldots \ldots \ldots \ldots
$$

Onde: $\mathrm{A}$ é a estimativa de perda de solo em Mg/ha, $\mathrm{El}_{30}$ é o parâmetro erosividade da chuva, EIA é o parâmetro erosividade da chuva-enxurrada e a, b e c são os coeficientes de regressão a serem ajustados.

Considerando a hipótese de que existiria uma relação não linear entre as perdas de solo e os parâmetros EI e EIA respectivamente, é 
que Lombardi Neto (1979) e Foster et al. (1982) propuseram as seguintes equações:

$$
\begin{aligned}
A & =a\left(E I_{30}\right)^{b} \ldots \ldots \ldots \ldots \ldots \ldots \ldots \ldots
\end{aligned}
$$

Onde: A é a estimativa de perda de solo em Mg/ha; $\mathrm{El}_{30}$ é o parâmetro erosividade da chuva; ElA é o parâmetro erosividade da chuva-enxurrada. e a e b são os coeficientes de regressão a serem ajustados.

Objetivando verificar a relação entre as perdas de solo e o volume de enxurrada $\left(V_{u}\right)$, é que foi proposto o parâmetro erosividade da enxurrada. Portanto, a equação linear que expressa esse parâmetro é a seguinte (Lombardi Neto, 1979 e Foster et al., 1982):

$$
A=a+b \cdot v_{u} \ldots \ldots \ldots \ldots \ldots
$$

Onde: $A$ é a estimativa de perda de solo em $M g / h a ; ~ V_{u}$ é o volume de enxurrada e $\mathbf{a}$ e $\boldsymbol{b}$ são os coeficientes de regressão a serem ajustados.

Também foi proposto outro parâmetro erosividade da enxurrada, expresso por uma equação não linear, objetivando verificar se existiria um efeito não linear entre as perdas de solo e a enxurrada, expresso pela seguinte equação (Lombardi Neto, 1979 e Foster et al., 1982):

$$
A=a\left(v_{u}\right) b \ldots \ldots \ldots \ldots \ldots
$$


Onde: $\mathrm{A}$ é a estimativa de perda de solo em $\mathrm{Mg} / \mathrm{ha} ; \mathrm{V}_{\mathrm{u}}$ é o volume de enxurrada e a e b são os coeficientes de regressão a serem ajustados.

Meyer et al. (1975) consideraram a hipótese de que o processo erosivo poderia ser estimado com maior precisão, através de modelos matemáticos, caso o referido processo fosse representado matematicamente por dois subprocessos distintos a saber: erosão em sulcos e ercsão entresulcos. Considerando que os parâmetros, El $30, V_{u}$ e EIA poderiam representar a erosão entresulcos e em sulcos respectivamente, é que Lombardi Neto (1979) e Foster et al. (1982) propuseram as seguintes equações:

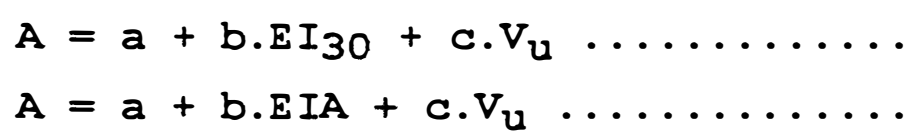

Onde: A é a estimativa de perda de solo em Mg/ha; EI30 é o parâmetro erosividade da chuva; EIA e o parâmetro erosividade da chuva enxurrada, Vu é o parâmetro erosividade da enxurrada e a, b e c são os coeficientes de regressão a serem ajustados.

O impacto das gotas de chuva é o processo dominante no desagregamento das partículas de solo nas áreas em que ocorre a erosão entresulcos (Meyer et al., 1975). Por outro lado, o delgado fluxo da enxurrada que ocorre nas áreas de erosão entresulcos, tem pouca capacidade de desagregação e transporte dos sedimentos na ausência do impacto das gotas de chuva. Entretanto, na presença do impacto das gotas de chuva, a capacidade de transporte da enxurrada na área em que ocorre a erosão entresulcos é grande. Grande parte das partículas desagregadas na área em que ocorre a erosão entresulcos, são transportadas pela enxurrada, do que diretamente pelo salpicos das gotas de chuva (Lombardi Neto, 1979 e Owoputi \& Stolte, 1995) 
A enxurrada é o fator dominante na determinação das perdas de solo nas áreas em que ocorre a erosão em sulcos. A erosão em sulcos começa quando a capacidade de desagregamento da enxurrada excede a capacidade das partículas do solo de resistir ao desagregamento da enxurrada. Após o início do processo da erosão em sulco, a enxurrada tende a se concentrar aumentando a sua capacidade de desagregamento e transporte, mormente pelo turbilhamento e o efeito abrasivo, decorrente do movimento da enxurrada dentro dos sulcos (Lombardi Neto, 1979 e Owoputi \& Stolte, 1995).

Uma modificação da EUPS foi proposta por Williams (1975). A equação universal de perdas de solo modificada (MEUPS) por Williams (1975), difere da (EUPS) no que diz respeito a substituição do fator $R$, por um fator com base no escoamento superficial. $O$ autor constatou, que 0 parâmetro erosividade da enxurrada, que combinava o volume e a taxa da enxurrada, apresentou melhor correlação com as perdas de solo do que o parâmetro erosividade da enxurrada, que considerava apenas o volume de enxurrada. $O$ parâmetro erosividade da enxurrada, foi expresso pela seguinte equação:

$$
A=a\left(V_{u} \cdot \sigma_{p u}\right)^{b} \ldots \ldots \ldots \ldots
$$

Onde: $A$ é a estimativa de perda de solo $(t / m) ; V_{u}$ é o volume de enxurrada $\left(\mathrm{m}^{3}\right)$; $\sigma_{\mathrm{pu}}$ é a taxa do pico de enxurrada $\left(\mathrm{m}^{3} / \mathrm{s}\right)$ e a e b são os coeficientes de regressão a serem ajustados.

Considerando que a taxa do pico da enxurrada, não foi calculado para a enxurrada coletada nas parcelas experimentais, e que o mesmo poderia ser expresso pelo termo: $(\alpha .130)$, então substituindo-se este termo na equação (29), obtém-se a equação (30) como sugerida por Lombardi Neto (1979) e Foster et al.(1982): 


$$
A=a\left(V_{u} \cdot \alpha \cdot I_{30}\right)^{b}, \ldots \ldots
$$

Onde: $\mathrm{A}$ é a estimativa de perda de solo $\mathrm{Mg} / \mathrm{ha} ; \mathrm{V}_{\mathrm{u}}$ é o volume de enxurrada $(\mathrm{mm}) ; \alpha$ é a relação entre o volume de enxurrada e o volume de chuva $\left(V_{u} N_{r}\right)^{1 / 2} ; I_{30}$ é a intensidade máxima em 30 minutos e a e b são os coeficientes de regressão a serem ajustados.

A inclusão do termo ( $\alpha .130)$, como estimador da taxa do pico da enxurrada, é exclusivamente matemática, visto que, $\sigma_{\mathrm{pu}}=\alpha$. I30. Portanto, outro parâmetro erosividade da enxurrada semelhante ao de Williams (1975), foi dado pela seguinte equação:

$$
A=a\left(V_{u} \cdot \alpha \cdot I_{5}\right)^{b} \ldots \ldots \ldots
$$

Onde: $A$ é a estimativa de perda de solo $\mathrm{Mg} / \mathrm{ha} ; \mathrm{V}_{\mathrm{u}}$ é o volume da enxurrada; $\alpha$ é a relação entre o volume de enxurrada e o volume de chuva $\left(V_{\mathrm{u}} N_{\mathrm{r}}\right)^{1 / 2}$; 15 é a intensidade máxima em 5 minutos minutos e a e b são os coeficientes de regressão a serem ajustados..

Considerando, que a taxa do pico da enxurrada ( $\sigma p u)$, não foi mensurada nas parcelas experimentais e que a referida taxa foi substituída pela expressão ( $\alpha$. 130), é que Lombardi Neto (1979) e Foster at al. (1982), propuseram os seguintes parâmetros erosividade da chuva-enxurrada:

$$
\begin{aligned}
& A=a+b(1 / 2) I_{30}+c(1 / 2) V_{u}\left(\alpha \cdot I_{30}\right)^{1 / 3} \ldots \\
& A=a+b(1 / 2) E I_{30}+c(1 / 2) V_{u}\left(\alpha . I_{5}\right)^{1 / 3} \ldots \\
& A=a+b E I A+c V_{u}\left(\alpha \cdot I_{30}\right)^{1 / 3} \ldots \ldots \\
& A=a+b E I A+c V_{u}\left(\alpha \cdot I_{5}\right)^{1 / 3} \ldots \ldots
\end{aligned}
$$

Onde: : A é a estimativa de perda de solo Mg/ha; El30 é o parâmetro erosividade da chuva; EIA é o parâmetro erosividade da chuva- 
enxurrada para o tempo da enxurrada; $V_{\mathrm{u}}$ é o volume de enxurrada; $\alpha$ é a relação entre o volume de enxurrada e o volume de chuva $\left(V_{U} N_{r}\right)^{1 / 2} ; 15$ e 130 são a intensidade máxima em 5 e 30 minutos respectivamente e $\mathbf{a}, \mathbf{b}$ e $\mathbf{c}$ são os coeficientes de regressão a serem ajustados...

Williams et al. (1971) analisando a correlação entre parâmetros erosividade da chuva e enxurrada com as perdas de solo de 5 bacias hidrográficas do Texas (USA), constataram que o parâmetro erosividade da enxurrada dado pela expressão $\sigma_{\mathrm{pu}} N_{\mathrm{u}}$; onde: $\sigma_{\mathrm{pu}}$ é taxa do pico de descarga do escorrimento superficial e $V_{u}$ é o volume do escorrimento superficial, apresentaram melhor correlação com as perdas de solo, do que os parâmetros erosividade da chuva tais como: volume da chuva, 130 , tempo de ocorrência, energia cinética e o $\mathrm{El}_{30}$.

Williams (1975) utilizando um parâmetro erosividade da enxurrada em substituição ao parâmetro erosividade da chuva na EUPS dado pela expressão: $\sigma_{\mathrm{pu}} N_{\mathrm{u}}$; onde: $\sigma_{\mathrm{pu}}$ é taxa do pico de enxurrada e $V_{\mathrm{u}}$ é o volume da enxurrada, constatou que a MEUPS estimou as perdas de solo com mais precisão que aquela expressa pela equação original. A MUSLE explicou $92 \%$ da variação da produção de sedimentos de 18 pequenas microbacias.

Williams \& Berndt (1977), relatam que para 12 locais dos E.U.A, a MEUPS explicou em torno de $80 \%$ das variações da produção de sedimentos para chuvas individuais.

Dragoun \& Miller (1964), correlacionando parâmetros erosividade da chuva e enxurrada com perdas de solo de duas bacias hidrográficas nas condições edafoclimáticas do Estado do Nebraska (E.U.A), constataram que o parâmetro erosividade da enxurrada, expresso pela soma entre o volume da enxurrada e a taxa do pico de descarga da enxurrada, foi o que melhor explicou as perdas de solo, apresentando coeficientes de correlação (r) que variaram entre 0,81 e 0,98. 
Estudando as correlações entre parâmetros erosividade da chuva, enxurrada e chuva-enxurrada para 10 locais do E.U.A, Lombardi Neto (1979) estabeleceu as seguintes conclusões: a) a combinação do fator erosividade da enxurrada, com um fator erosividade da chuva, melhorou significativamente a estimativa das perdas de solo para chuvas erosivas, b) Os parâmetros erosividade da enxurrada: EIA, $\left(V_{u} \cdot \alpha .130\right)^{a}$ e $V_{u} \cdot(\alpha .130)^{1 / 3}$, apresentaram uma melhor correlação com as perdas de solo do que o termo El.

Carvalho (1992) correlacionou vários parâmetros erosividade da chuva, da enxurrada e chuva-enxurrada para Campinas(SP), Mococa(SP) e Pindorama(SP). O autor analisando os resultados obtidos, estabeleceu as seguintes conclusões: a) os fatores não lineares simples tais como: $a(E I A)^{b}, a\left(V_{u} \cdot \alpha .15\right)^{b}$ e $V_{u} \cdot(\alpha .130)^{1 / 3}$, com especial destaque ao primeiro, devem ser empregados como preditores da erosividade da chuva e enxurrada para as chuvas individuais do Estado de São Paulo e b) os parâmetros da chuva do tipo $\mathrm{El}_{25}$, El30 e KE>25 constituem-se em parâmetros satisfatórios para avaliar a erosividade da chuva.

\subsection{Fator erodibilidade do solo (Fator $\mathrm{K}$ )}

Nas condições edafoclimáticas do semi-árido brasileiro, os valores do fator erodibilidade do solo $(K)$, obtidos através de chuva natural, são escassos e de uma forma geral não seguem as recomendações da parcela padrão (Wischmeier \& Smith 1978 e Albuquerque, 1993).

Os resultados obtidos com simuladores de chuva são mais abundantes, sendo portanto, a maior contribuição para o estudo do fator $\mathrm{K}$ no Nordeste do Brasil e particularmente em sua região semi-árida (Leprun, 1988; Denardin, 1991 e Albuquerque, 1993).

$\mathrm{O}$ fator $\mathrm{K}$ pode variar muito ao longo do ano, sendo que este fato ocorre devido a diferentes valores de $A$ e $R$, mormente quando a 
seqüência das chuvas são irregulares como no caso do semi-árido do Nordeste (Leprun, 1988). O autor acrescenta que ao longo do tempo, o fator $\mathrm{K}$ pode variar muito, aumentando a medida que o solo vai sendo cultivado no decorrer do anos subsequentes, ou seja quando se afasta da época do desmatamento. O autor esclarece que este fato ocorre devido a vários fatores tais como: diminuição da estabilidade estrutural após o desmatamento e sucessivos cultivos, diminuição do teor de carbono e sobretudo pela diminuição da permeabilidade.

O pavimento desértico característico do solo Bruno Não Cálcico, constituídos de calhaus e matacões de quartzo rolados, serve como agente protetor, interceptando o impacto das gotas de chuva sobre o solo, por conseguinte interferindo diretamente no processo erosivo. Segundo Silva et al. (1986) o baixo valor obtido (0,006 t.ha.h/ha.MJ.mm) para a erodibilidade de um solo Bruno Não Cálcico, não deferiu daqueles encontrados para os solos Litólicos (0,006 t.ha.h/ha.MJ.mm), devido ao fato de que o pavimento desértico do solo Bruno não Cálcico ao interceptar as gotas de chuvas e atenuar a ação desagregadora do impacto da gota de chuva sobre o solo, contribuiu para que o solo Bruno Não Cálcico apresentasse um comportamento idêntico ao Litólico.

$O$ fator erodibilidade do solo $(K)$, foi definido como sendo $\mathrm{o}$ incremento médio na perda de solo, para cada unidade adicionada do fator $R$, ou seja, $K=A / R$ (Wischmeier \& Smith 1978). Esta condição se dá, quando os fatores $L, S, C$ e $P$ forem iguais a um. Portanto, o fator $K$, combina em um único número, os efeitos das características do solo relativos a sua capacidade de infiltração e a sua susceptibilidade em se desagregar e de ser transportado pela enxurrada (Wischmeier \& Smith, 1978).

Existe uma relação funcional entre as perdas de solo e o parâmetro erosividade da chuva, que pode ser expressa pelo modelo linear simples: $A=a+b E I_{30}$, onde: $A$ é a estimativa da perda de solo (variável dependente) e $\mathrm{El}_{30}$ é o parâmetro de erosividade da chuva (variável 
independente). No modelo linear simples, o fator "K" é representado pelo coeficiente de regressão "b", quando os dados obtidos são oriundos de parcela padrão (Wischmeier \& Smith, 1978).

Nas condições do semi-árido do Nordeste do Brasil, os valores do fator $\mathrm{K}$ para o solo Bruno Não Cálcico são escassos. Os poucos dados relatados para o semi-árido do Nordeste são os seguintes: 0,008 e 0,044 tha h/ha MJ mm (Denardin, 1991).

\subsection{O desmatamento do semi-árido do Nordeste do Brasil}

O Trópico Semi-árido brasileiro, abrange uma área de 115 milhões de hectares $\left(1.150 .662 \mathrm{~km}^{2}\right)$, correspondendo a $74,3 \%$ da área da região do Nordeste do Brasil e a $13,5 \%$ do território nacional. Esta região é maior do que a área individual de 32 países, dos 33 que compõem a Europa (Secretaria Especial do Meio Ambiente - SEMA, 1986).

A chamada Zona da Mata de Pernambuco, a partir de Olinda e o Recôncavo baiano a partir de Salvador, foram os dois grandes centros de expansão do povoamento da região do Nordeste do Brasil. Os sesmeiros ao avançarem da zona da mata para o interior, encontraram áreas de domínio de clima seco. Portanto, deixaram os canaviais e engenhos insulados nos vales dos rios e várzeas, ocupando as áreas mais secas com a pecuária (SUDENE, 1989).

Foi a ocupação da área úmida pela cana-de-açúcar, que provocou o povoamento da região semi-árida do Nordeste do Brasil, uma vez que a penetração para o interior foi feita em função da criação de gado bovino com fins de produção de carne e de animais de trabalho para os engenhos de açúcar. A ocupação foi feita sobretudo em função da pecuária ultra-extensiva em campo aberto (Andrade, 1982). 
Cada engenho era um grande consumidor de madeira, sendo que a madeira derrubada, era utilizada na construção civil, na fabricação de utensílios, carros de boi, móveis e, principalmente, para alimentar as fornalhas dos engenhos. Além disso, uma grande demanda por madeira era oriunda da necessidade de confecção de caixas, onde o açúcar era acondicionado para a exportação, contribuindo para o desmatamento de extensas áreas de mata atlântica (SUDENE, 1989).

A medida que a ocupação da região semi-árida do Nordeste era feita, as mesmas práticas de desmatamento indiscriminado; utilizadas para a ocupação da área úmida, passou a ser utilizada na ocupação do semi-árido do Nordeste do Brasil.

Com a ocupação da região semi-árida, o sistema de queima da caatinga - a coivara - também foi intensificado, a fim de que os pastos se desenvolvessem de forma exuberante, após a chuva. A utilização de queimada nas atividades agropecuária tornou-se portando uma prática cultural que até hoje predomina na região, mormente com o objetivo de aumentar a capacidade de lotação das fazendas. Portanto, o machado e o fogo tornaramse práticas agropecuária profundamente enraizadas na região semi-árida do Nordeste do Brasil, contribuindo para afetar o frágil equilíbrio ecológico da região (Andrade, 1982).

A região semi-árida do Nordeste do Brasil, se prestava bem para a pecuária extensiva, pois era rica em gramíneas na estação chuvosa, e em leguminosas e cactáceas no período da seca. Entretanto, a utilização freqüente do uso das queimadas, contribuiu para a devastação dessa vegetação natural, contribuindo por conseguinte para intensificar a ação dos agentes erosivos (Andrade, 1982).

A degradação do meio ambiente no semi-árido nordestino, iria se intensificar, quando para abastecer o mercado europeu, em face do crescimento de indústria têxtil, foi o Nordeste brasileiro utilizado como 
área produtora de algodão para exportação. A expansão dos algodoais provocaria um grande desmatamento na área de caatinga, onde a malvácea passou a ser cultivada em larga escala, associada ao milho, à fava e ao feijão (SUDENE, 1989).

A derrubada da vegetação nativa intensificou-se mais ainda, quando se difundiu a cultura do café na região semi-árida do Nordeste do Brasil, visto que, a mesma necessitava de solos férteis e de clima de altitude para se desenvolver. A instalação da cultura do café teve um impacto muito grande sobre a vegetação, derrubando grandes áreas de florestas. Assim, a cultura do café passou a ocupar as serras em encostas que muitas vezes tinham declives acentuados, contribuindo para intensificar os processos erosivos (SUDENE, 1989).

Quase sempre a derrubada da floresta mudava as condições ecológicas, e quando uma área antes cultivada era deixada em pousio, a capoeira que reconstituia a floresta era predominante em espécies da caatinga. Não havia mais umidade suficiente para que a floresta se reconstituísse em sua composição primitiva. Assim, áreas anteriormente de mata se transformaram em caatinga, que expandiam a sua área de influência, em detrimento de uma associação vegetal que necessitava de condições climáticas mais úmidas. Embora, a caatinga sempre houvesse sido uma composição florística xerófila, era, contudo, bem mais densa, revestindo o solo com capacidade suficiente, para manter no conjunto, a continuidade do equilíbrio edafoclimático que Ihe era característico (Vasconcelos Sobrinhos, 1974 e Vasconcelos Sobrinho, 1983).

Dentro deste contexto, Vasconcelos Sobrinho (1974) adverte que o equilíbrio instável, característico do semi-árido do Nordeste do Brasil, foi quebrado em grande parte do seu território, estando a implantar-se em progressão acelerada, condições que evoluem para a desertificação. 
Atualmente, a utilização da caatinga ainda se fundamenta em processos meramente extrativista para a obtenção de produtos de origem pastoril, agrícola ou florestal. As conseqüências deste modelo extrativista predatório se fazem sentir principalmente nos recursos naturais renováveis da caatinga. No que tange à vegetação, pode-se afirmar que acima de $80 \%$ da caatinga são sucessionais, cerca de $40 \%$ são mantidos em estado pioneiro de sucessão secundária e a desertificação já se faz presente em aproximadamente, $15 \%$ da área (Araújo Filho \& Carvalho, 1996).

Assim, a destruição da flora com a conseqüente perda da diversidade florística tem contribuído para acelerar o processo de erosão do solo, trazendo como conseqüências o assoreamento dos rios e dos açudes públicos e privados.

As alterações sofrida nos últimos decênios pelo regime hídrico dos afluentes da bacia do São Francisco pode ser visualizado, quando se constata que os gráficos dos picos das enchentes são cada vez mais altos e mais rápidos. Este fato expressa um fenômeno ecológico: a ausência cada vez maior da cobertura vegetal na bacia do São. Portanto, as enchentes da região semi-árida, que ocorrem de forma rápida, mas que são avassaladoras, tem em grande parte sido influenciada pelo desmatamento generalizado, que proporciona um intenso escoamento superficial (Vasconcelos Sobrinho, 1974)

São escassas as pesquisas realizadas no semi-árido Nordestino, objetivando avaliar o efeito do desmatamento da Caatinga sobre as perdas de solo e água. Ramos \& Marinho (1980) ao avaliarem o efeito do desmatamento da caatinga sobre as perdas de solo de um solo Litólico, através de chuva simulada, constataram que a parcela desmatada contribuiu com uma perda de 115,4 t/ha. As parcelas com caatinga e extrato herbáceo contribuíram com perdas de 1,2 e 8,6 t/ha respectivamente, reduzindo as perdas de solo em 99 e 92,6\%. Os autores constataram também que o desmatamento reduziu a infiltração em 41,5\%. A magnitude das perdas de solo decorrente do 
desmatamento é extraordinária, mormente quando se considera a tolerância de perda de solo de um solo Litólico, que é praticamente nula.

\subsection{O efeito do manejo do solo sobre as perdas por erosão}

A metade dos países do planeta, possuem parte ou totalidade de suas áreas, constituídas por zonas áridas ou semi-áridas. As terras áridas, representam um terço da superfície terrestre, e nelas vivem $15 \%$ da população mundial. A magnitude e gravidade do problema, assume proporções alarmantes, visto que, a cada ano, $50.000 \mathrm{~km}^{2}$ de novos desertos se acrescentam aos desertos já existentes (FAO, 1993a,b).

Dentro deste contexto deve-se destacar, que a região semi-árida do Nordeste do Brasil, está incluída no mapa das Nações Unidas sobre desertificação, sendo classificada como uma região de alto risco (Vasconcelos Sobrinho, 1971).

Do ponto de vista climático, o semi-árido do Nordeste do Brasil é caracterizado por uma precipitação pluviométrica (400 a $700 \mathrm{~mm}$ ) bastante irregular e distribuída ao longo de 5 meses, resultando geralmente na redução drástica ou perda total da produção agrícola (Albuquerque, 1993).

A região semi-árida do Nordeste do Brasil, além de possuir vocação ecológica para a desertificação, devido à ocorrência de secas e às características de clima e solo, tem na ação do homem, favorecida pela pressão demográfica (a área seca do Nordeste possui uma população ao redor de 20 milhões de pessoas), a responsável maior pelo alarmante processo de desertificação que a região está sofrendo (Vasconcelo Sobrinhos 1974; Mendes, 1986 e Melo, 1988).

A degradação dos recursos naturais, é função do mau uso dos recursos naturais pelo homem, do que à ação dos fatores climáticos. Embora as secas contribuam de maneira marcante para a desertificação, 
constata-se que, quando não ocorre a intervenção humana, os ecossistemas naturais se recuperam, entretanto quando o sistema natural se encontra debilitado pela sua utilização inadequada, os efeitos das secas são muito mais drásticos para a deterioração ambiental (Vasconcelos Sobrinho, 1983; Mendes, 1986, Reis, 1988 e FAO, 1993a,b)

Portanto, o Polígono das Secas, por apresentar, na maior parte do ano, solos secos, quentes e desprotegidos, torna-se um ambiente propício para que a erosão hídrica, a erosão eólica e a oxidação da matéria orgânica, ocorram de forma intensa (Mendes, 1986).

A maneira de se explorar os recursos naturais e de fazer agricultura no Semi-árido nordestino é inadequada e predatória. O indiscriminado desmatamento da caatinga para a preparação de novos roçados, os quais são feitos a curtos intervalos de tempo (de dois em dois anos); visto que, os solos rapidamente se esgotam, condicionam a prática de uma agricultura itinerante, que é uma das atividades que mais contribuem para o processo de degradação do solo (Vasconcelos Sobrinho, 1974; Mendes, 1986 e Reis, 1988).

O aumento da demanda de alimentos, resultante do aumento demográfico, resultou num uso mais intensivo da terra, encurtando o tempo de pousio. Conseqüentemente, o tempo de pousio tornou-se insuficiente para que os processos de sucessão pudessem recompor a vegetação e a fertilidade do solo (Araújo Filho \& Carvalho, 1996).

Dos trabalhos de pesquisa desenvolvidos no semi-árido do Nordeste do Brasil, os realizados pelo Eng Agrônomo Moacyr Brito, merecem destaque especial devido ao pioneirismo, a visão holística e adaptação à realidade do trópico Semi-árido do Nordeste do Brasil.

Na década de 1940, o Eng Agrônomo Moacyr Brito, proprietário da Indústria Peixe, começava por iniciativa própria, estudar em Pesqueira-PE de forma sistemática e ininterrupta durante um período de 22 
anos, o efeito do manejo do solo sobre as perdas por erosão no semi-árido do Nordestedo Brasil, objetivando conservar e melhorar suas potencialidades edáficas. Os resultados deste trabalho são descritos por Freitas et al. (1981).

$O$ efeito de diferentes tipos de manejo do solo, sobre as perdas de solo, num Regossolo de Pesqueira-PE, foi estudado por Freitas et al. (1981). Analisando os dados obtidos, os autores chegaram as seguintes conclusões: 1) o solo lavrado e com cultivo contínuo de tomate resultou numa perda de 100 t/ha de solo; 2) o solo lavrado e com rotação bienal (tomate e feijão-de-porco incorporado) contribuiu com uma perda de solo de 50 t/ha e 3) o solo não lavrado e com rotação bienal (tomate e feijão-de-porco deixado na superfície), contribuiu para perdas por erosão em 8 t/ha.

A análise de um segundo experimento que objetivava comparar o efeito de diferentes tipos do manejo do solo, sobre as perdas de solo e água num Regossolo de Pesqueira-PE, foi realizadas por Freitas et al. (1981). Analisando os dados obtidos, os autores constataram as seguintes conclusões: 1) as rotações bienais e trienais de tomate com leguminosa e capoeira deixadas na superfície do solo, contribuíram para reduzir entre 71 e $97 \%$ as perdas de solo e entre 64 e $93 \%$ as perdas de água, quando comparada com o plantio contínuo de tomate e 2) as rotações bienal e trienal, com capoeira deixadas na superfície, quando comparadas com o tratamento de cultivo contínuo de tomate, provocaram uma redução das perdas de solo de 94,6 e $97,2 \%$ e às perdas de água em $87,6 \%$ e $93,2 \%$ respectivamente.

Com base nos resultados obtidos em Pesqueira-PE, Freitas et al. (1981) propuseram algumas recomendações, objetivando a manutenção da capacidade produtiva do solo estudado, a saber: 1) evitar o máximo possivel a movimentação do solo pelos implementos agrícolas; 2) adotar a rotação de cultura nos sistemas de manejo do solo; 3) utilizar a prática de pousio do solo por um período mínimo de dois anos; 4) a vegetação nativa surgida no período de pousio deve ser ceifada e deixada sobre a superfície do 
solo para formar uma cobertura morta antes do plantio seguinte; 5 ) as práticas de rotação de cultura e pousio do solo serão mais eficientes se forem feitas em faixas.

Apesar da importância agrícola da palma forrageira no contexto do semi-árido nordestino, são escassos os trabalhos científicos abordando o efeito do manejo desta cultura sobre as perdas de solo e água. Margolis et al. (1985) relataram perdas de solo da ordem de 2,0 tha para a palma forrageira cultivada num solo Litólico de Caruaru-PE.

Num Podzólico Vermelho Amarelo localizado no Estado do Ceará, Melo Filho \& Silva (1993) pesquisando o efeito do plantio na palha e do preparo convencional, sobre as perdas de solo e água, constataram que o preparo convencional resultou em perdas de solo e de água da ordem de 30,9 tha e $233 \mathrm{~mm}$ respectivamente, enquanto que o plantio na palha resultou em perdas de solo e água de 3,0 tha e $184 \mathrm{~mm}$, respectivamente. Os autores concluíram, que o plantio na palha contribuiu para a redução de $90 \%$ das perdas de solo e em $21 \%$ as perdas de água.

Sousa et al. (1993) estudando o efeito da cobertura vegetal em relação à erosão num solo Bruno Não Cálcico de Serra Talhada$P E$, concluíram que: a) a cobertura nativa apresentou as menores perdas médias anuais de terra e água com 0,16 tha e 59,2 $\mathrm{mm}$ e b) as maiores perdas ocorreram na cobertura constituída de algodão arbóreo, palma e sorgo granífero, com um aumento em torno de $340 \%$ nas perdas de terra e $230 \%$ nas perdas de água em relação a vegetação nativa.

A tolerância de perda de solo para alguns solos do Estados de Pernambuco, foi estudada por Galindo \& Margolis (1989). Os autores relataram que os solos com horizonte B textural, apresentaram limites de tolerâncias de perdas de solo intermediários. No entanto, o solo Bruno Não Cálcico Vértico, mostrou o menor limite tolerável em função de características tais como: pouca profundidade, baixo teor de matéria orgânica, mudança 
textural abrupta, restrição a drenagem e horizonte A fracamente desenvolvido e mal-estruturado. O limite de tolerância para o solo Bruno Não Cálcico Vértico variou de 0,09 a $0,10 \mathrm{~mm} / a n$. Para o solo Bruno Não Cálcico textura média/argilosa, os valores de tolerância de perdas de solo variou de 0,25 a $0,28 \mathrm{~mm} / \mathrm{ano}$.

Tomando como base uma densidade do solo da ordem

de $1,4 \mathrm{t} / \mathrm{m}^{3}$, os valores de tolerância para o solo Bruno Não Cálcio Vertico (Galindo \& Margolis, 1989), seriam de 1,40 e 1,26 tha respectivamente. Portanto, os baixos valores obtidos para a tolerância de perda de solo, indicam a necessidade de um cuidado especial no manejo agrícola do solo Bruno Não Cálcico Vértico.

Vários estudos realizados no Nordeste do Brasil, objetivando avaliar o efeito de diferentes niveis de cobertura sobre as perdas de solo, obtiveram para a parcela desprovida de vegetação e cultivada morro abaixo perdas que variaram de 30 a 151 tha. Os autores advertem para a necessidade de medidas preventivas de controle da erosão, mormente para os solos localizados no semi-árido nordestino, caracterizados por baixa profundidade, baixos teores de matéria orgânica e horizonte $B$ textural (Ramos \& Marinho, 1980; Margolis \& Campos Filho, 1981; Freitas et al., 1981; Margolis et al, 1985; Silva et al., 1989; Margolis et al, 1991; Melo Filho \& Silva, 1993).

A medida que se reduz a cobertura vegetal, através do desmatamento ou do cultivo, o solo fica mais exposto a ação do impacto das gotas de chuva, que dissipa a sua energia cinética sobre a superfície do solo. Dessa forma, a chuva modifica as condições físicas da superfície do solo, reduzindo a rugosidade superficial, a porosidade e a infiltração da água. Dentro deste contexto, destaca-se o selamento superficial, como uma das modificações mais importantes, decorrente da ação do impacto das gotas de chuva sobre a superfície do solo. $O$ selamento afeta principalmente a infiltração da água, contribuindo para intensificar o aumento do escoamento superficial. $O$ 
selamento superficial diminui a infiltração da água, mesmo quando as camadas inferiores do solo, ainda tem capacidade de absorção de água (Singer et al., 1981; Lopes et al., 1987; Amado et al., 1989; Bertol et al., 1989; Carvalho et al., 1990; Reichert \& Cabeda, 1992 e Anjos et al., 1994).

A cobertura do solo é o fator que mais exerce influência sobre a erosão, visto que os resíduos culturais ou plantas cultivadas, funcionam como uma barreira física interceptando o impacto das gotas de chuva sobre a superfície do solo. A interceptação do impacto das gotas de chuva sobre o solo, reduz a desagregação das partículas, o salpicamento e o transporte das partículas pela enxurrada (Carvalho et al., 1990; Levien et al., 1990; Derpsch et al., 1991; Reichert \& Cabeda, 1992; Anjos et al., 1994; Albert \& Neibling, 1994)

Por outro lado, a cobertura do solo diminui a velocidade e o volume da enxurrada, causando a deposição ou filtragem dos sedimentos. O efeito da cobertura do solo na redução da velocidade do escoamento superficial da água é explicado pela tortuosidade dos caminhos a serem percorridos pelo fluxo, imposta pelos resíduos, bem como pela barreira física proporcionada pelos resíduos culturais, impedindo o livre escoamento da água. A redução é tanto maior, quanto maior for a quantidade de resíduos culturais na superfície (Lopes et al., 1987; Ben-Hur et al., 1987; Bertol et al., 1989; Carvalho et al., 1990; Levien et al., 1990; Reichert \& Cabeda, 1992; Anjos et al., 1994; Steiner, 1994).

Um dos mais importantes efeitos dos resíduos culturais sobre a infiltração é o aumento do tempo de inicio da enxurrada, após se iniciar uma chuva (Albert \& Neibling, 1994). Carvalho et al. (1990), relataram que o tempo de inicio da enxurrada tendeu a aumentar com o aumento da percentagem de cobertura do solo, sendo também influenciado pela forma do manejo dos resíduos culturais. 
A intervenção humana em ecossistemas frágeis como o do semi-árido do Nordeste do Brasil, pode levar a região a um processo erosivo de grandes proporções, caso não se tomem medidas de controle, objetivando a conservação e o melhoramento dos seus recursos naturais.

A mensuração dos efeitos da intervenção humana; mormente a agrícola, sobre as perdas de solo e água por erosão hídrica pode ser realizada através de modelos de previsão de perdas de solo. Os modelos de previsão de perda de solo são de grande utilidade no planejamento dos recursos naturais de uma determinada região, indicando quais os fatores que estão exercendo maior pressão sobre as perdas de solo e água.

Dentre os modelos de previsão de perda de solo, a equação universal de perda de solo tem sido um dos mais utilizados no planejamento agrícola. Entretanto, os trabalhos abordados no presente trabalho, indicam que a aplicação efetiva da mesma no semi-árido do Nordeste do Brasil, requer que os seus parâmetros sejam pesquisados nas condições locais da região. 


\section{MATERIAL E MÉTODOS}

\subsection{Localização da área experimental}

Os dados utilizados para a realização do presente trabalho foram obtidos na Estação Experimental de Sumé-PB, pertencente a Universidade Federal da Paraíba (UFPB).

A estação experimental de Sumé, está localizada na propriedade Fazenda Nova no município de Sumé, Estado da Paraíba. Situa-se na altura do Km 118 da BR-412, entre as cidades de Sumé e Monteiro, fazendo parte da área superior da Bacia do Rio Paraíba, numa latitude de $7^{\circ} 40^{\prime}$ Sul, longitude $37^{\circ} 00^{\prime}$ Oeste e altitude entre 500 a $700 \mathrm{~m}$ acima do nivel do mar. Esta região, uma das mais secas do Nordeste do Brasil, é denominada Cariris Velhos, ou apenas Cariri (Figura 1).

\subsection{Descrição do clima}

De acordo com a classificação de Koeppen, a região de Sumé-PB está enquadrada no tipo climático BSH, ou seja, seco (semi-árido), caracterizado pela insuficiência das precipitações pluviométricas e temperaturas elevadas, apresentando uma alternância de duas estações nitidamente distintas, a saber: 1) uma estação seca que se estende de junho a janeiro, caracterizada por precipitações pluviométricas muito baixas ou nulas e 2) uma estação chuvosa ou de inverno, que compreende os meses de 
38

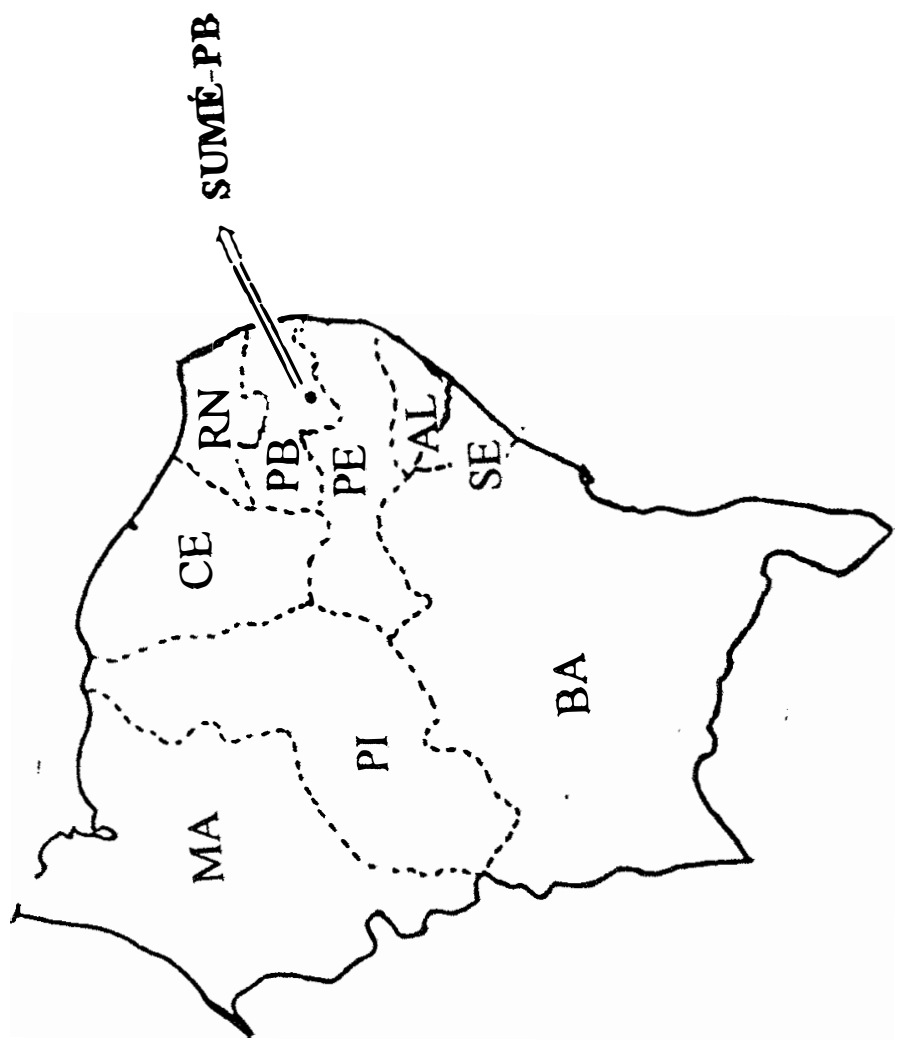

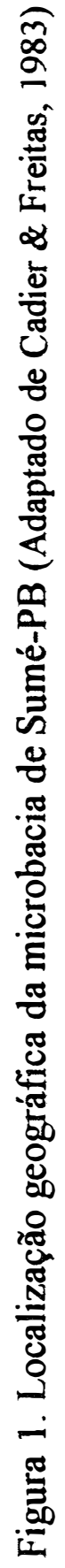


fevereiro, março, abril e maio, constituindo-se março e abril os meses de maior precipitação pluviométrica (Cadier et al., 1983).

A região onde está inserida a microbacia de Sumé, além de apresentar uma baixa precipitação pluviométrica é caracterizada por uma forte irregularidade climática interanual. A precipitação pluviométrica média anual é de $550 \mathrm{~mm}$. A temperatura média anual é de $24^{\circ} \mathrm{C}$ e a umidade relativa média anual é de $57 \%$. A insolação média anual é de 2.800 horas (Cadier et al., 1983).

A evaporação anual no tanque classe A é de $2.900 \mathrm{~mm}$, sendo que a evaporação é máxima nos meses de novembro e dezembro e é mínima nos meses de junho e julho (Molinier et al., 1989).

\subsection{Tipo de Solo}

O solo onde estão localizados os canteiros coletores de enxurrada foi classificado como: Bruno Não Cálcico Vértico, A fraco, textura argilosa, caatinga hiperxerófila. O solo Bruno Não Cálcico representa $60 \%$ dos solos da microbacia representativa de Sumé (Cadier et al., 1983). A descrição morfológica do solo Bruno Não Cálcico Vértico, a sua análise física e química, e o mapa das unidades de solo (Figura 12) da microbacia de Sumé-PB podem ser vistos no anexo $B$

\subsection{Geologia}

As rochas são cristalinas e fazem parte do embasamento pré-cambriano com cerca de $20 \%$ de granitos alcalinos que dão origem aos solos podzólicos, $60 \%$ de xistos, paranfibólito e gnaisse, onde se desenvolvem sobretudo os solos Bruno Não Cálcicos e $20 \%$ de gnaisse e quartzitos onde se desenvolvem os solos Litólicos. 
Estes três tipos de rochas são caracterizadas pela ausência de aquíferos generalizados, à exceção, de algumas fendas e zonas aluviais localizadas de pouca espessura.

\subsection{A cobertura vegetal e o uso atual}

A vegetação predominante da microbacia de Sumé-PB é a caatinga hiperxerófila densa, como de todo o Sertão dos Cariris Velhos.

A agricultura predominante é a de subsistência (milho, feijão e algodão) e se desenvolve em zonas de extensão limitada, nas unidades de solos mais favoráveis, basicamente nos solos podzólicos. A pecuária é extensiva e desenvolve-se em condições precárias.

\subsection{Pluviógrafo e pluviômetro}

Para o registro das chuvas correspondentes ao período de 1983 a 1990, foi utilizado um pluviógrafo do tipo IH com área de captação de $200 \mathrm{~cm}^{2}$, que funciona através do acionamento de um mecanismo de relógio com capacidade de registrar chuvas no decorrer de um período de vinte e quatro horas.

Nos pluviogramas as chuvas são registradas na ordenada de $0,1 \mathrm{~mm}$ em 0,1 mm, até atingir um total de $10 \mathrm{~mm}$, enquanto que 0 tempo é registrado na abcissa de dez em dez minutos durante um período de $24 \mathrm{~h}$.

Os dados pluviométricos foram obtidos a partir de um pluviômetro do tipo Ville DeParis, com área de captação de $400 \mathrm{~cm}^{2}$ e com capacidade máxima de $200 \mathrm{~mm}$ de chuva, onde o registro de altura de chuva é feita para cada período de $24 \mathrm{~h}$. 


\subsection{Descrição da estação experimental de Sumé-PB}

As instalações da estação experimental de Sumé-PB, são constituídas por uma estação meteorológica, quatro microbacias com áreas entre 0,5 e 1 ha e nove parcelas experimentais. O croqui da estação experimental de Sumé está apresentado na Figura 2.

\subsubsection{Descrição das microbacias experimentais}

Na tabela 1, podem ser vistas algumas características das microbacias estudadas.

Tabela 1. Características das microbacias estudadas.

\begin{tabular}{ccccl} 
Microbacias Área & Perímetro & $\begin{array}{c}\text { Declividade } \\
\text { Média }\end{array}$ & $\begin{array}{l}\text { Cobertura } \\
\text { Vegetal }\end{array}$ \\
\hline & ha & $(\mathrm{m})$ & $(8)$ & \\
M1 & 0,60 & 398 & 7,0 & Caatinga Nativa \\
M2 & 1,07 & 466 & 6,1 & Caatinga Nativa \\
M3 & 0,52 & 302 & 7,1 & Desmatada \\
M4 & 0,48 & 270 & 6,8 & Desmatada
\end{tabular}




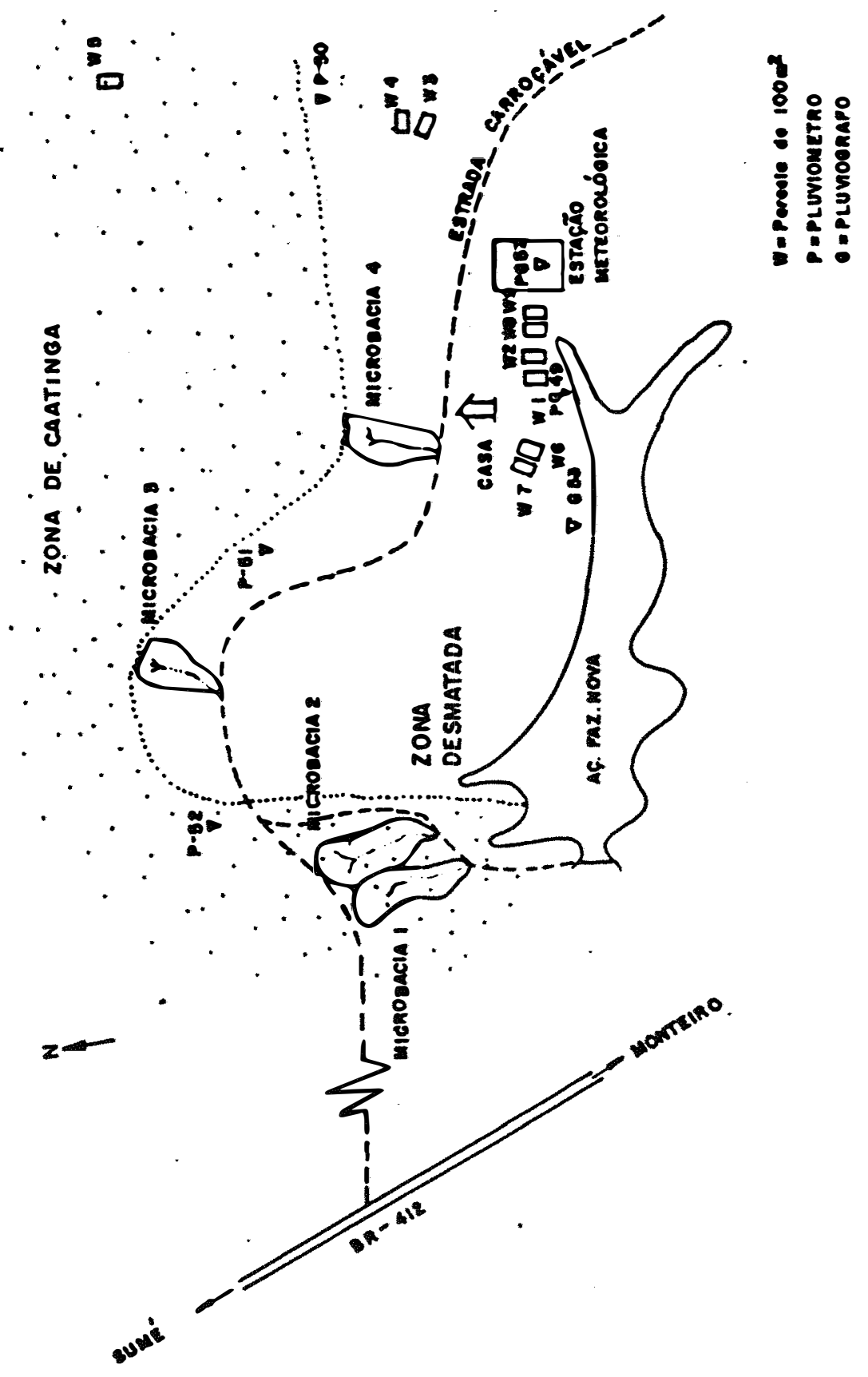

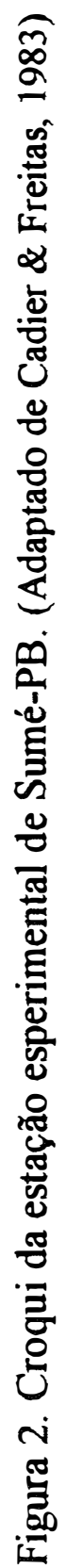


As microbacias possuem uma fossa de sedimentação retangular de cerca de 2300 litros de capacidade, equipada com um vertedor triangular de $90^{\circ}$ e dois linígrafos e um dispositivo de amostragem dos sedimentos transportados (Figura 3).

O vertedor foi dimensionado para uma vazão máxima, correspondente a uma descarga provocada por uma chuva com intensidade de $100 \mathrm{~mm} / \mathrm{h}$, que escoasse em sua totalidade sobre uma superfície de 1 ha com velocidade média de 0,2 a $0,3 \mathrm{~m} / \mathrm{s}$ no canal da fossa.

Durante a instalação foi realizado um levantamento topográfico para se determinar as características topográfica das microbacias (Cadier et al. 1983). O levantamento topográfico das quatro microbacias podem ser vistas no anexo A, através das figuras $8,9,10$ e 11 .

\subsubsection{Descrição das parcelas experimentais}

As parcelas experimentais, num número total de nove, foram instaladas gradativamente. As parcelas foram construída com 22,13 m de comprimento por $4,55 \mathrm{~m}$ de largura.

A jusante da parcela experimental está localizado o sistema coletor de terra e enxurrada, que é constituído por dois tanques de fibro-cimento de 1000 litros, dispostos em série e interligados com calhas divisoras de nove janelas do tipo Geib (Figura 4).

$\mathrm{Na}$ tabela 2 estão apresentadas as principais características das parcelas experimentais e 0 ano de instalação. 


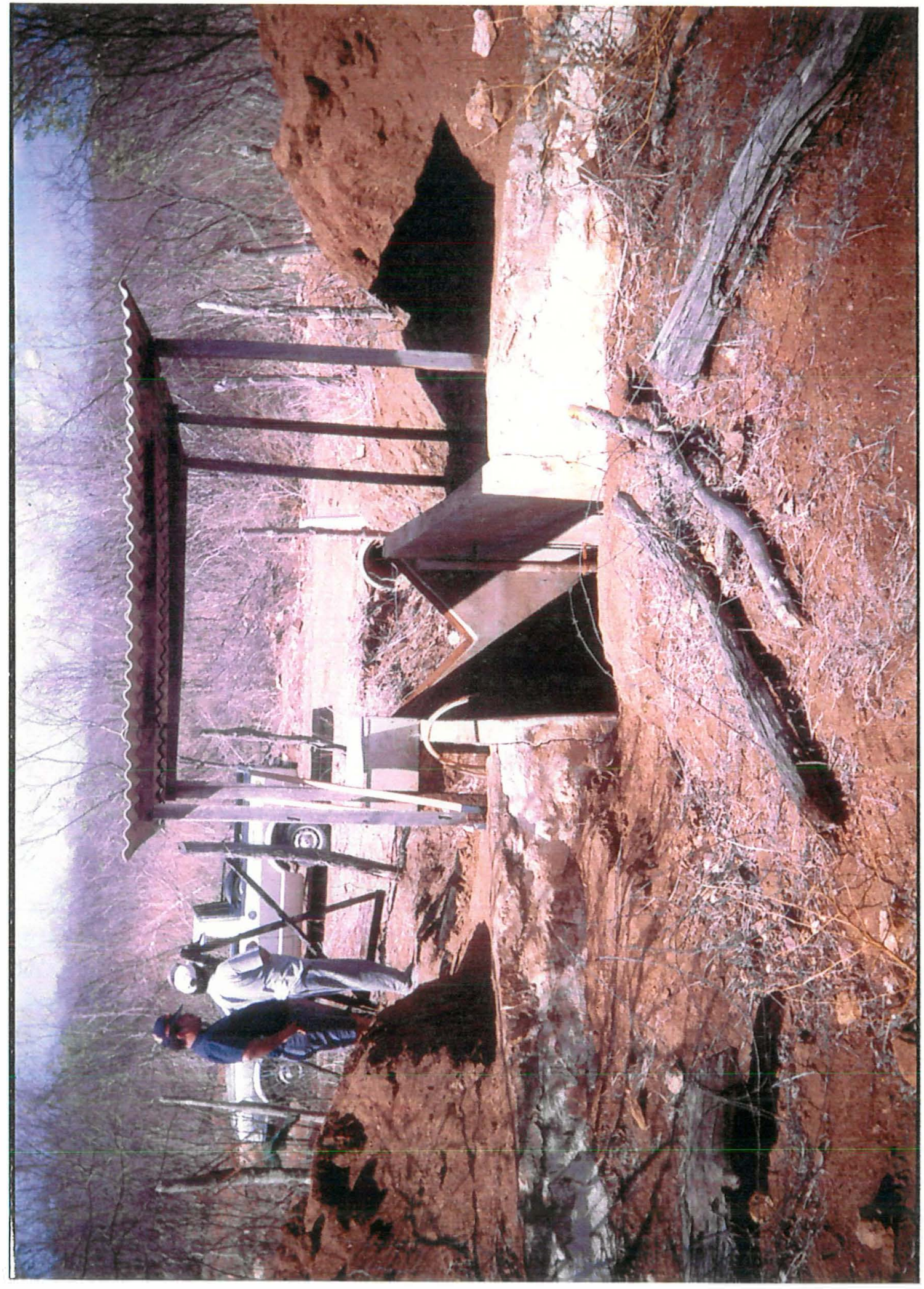

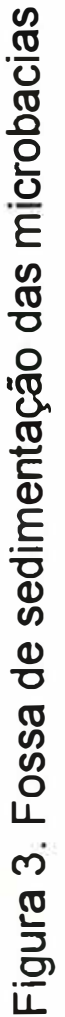




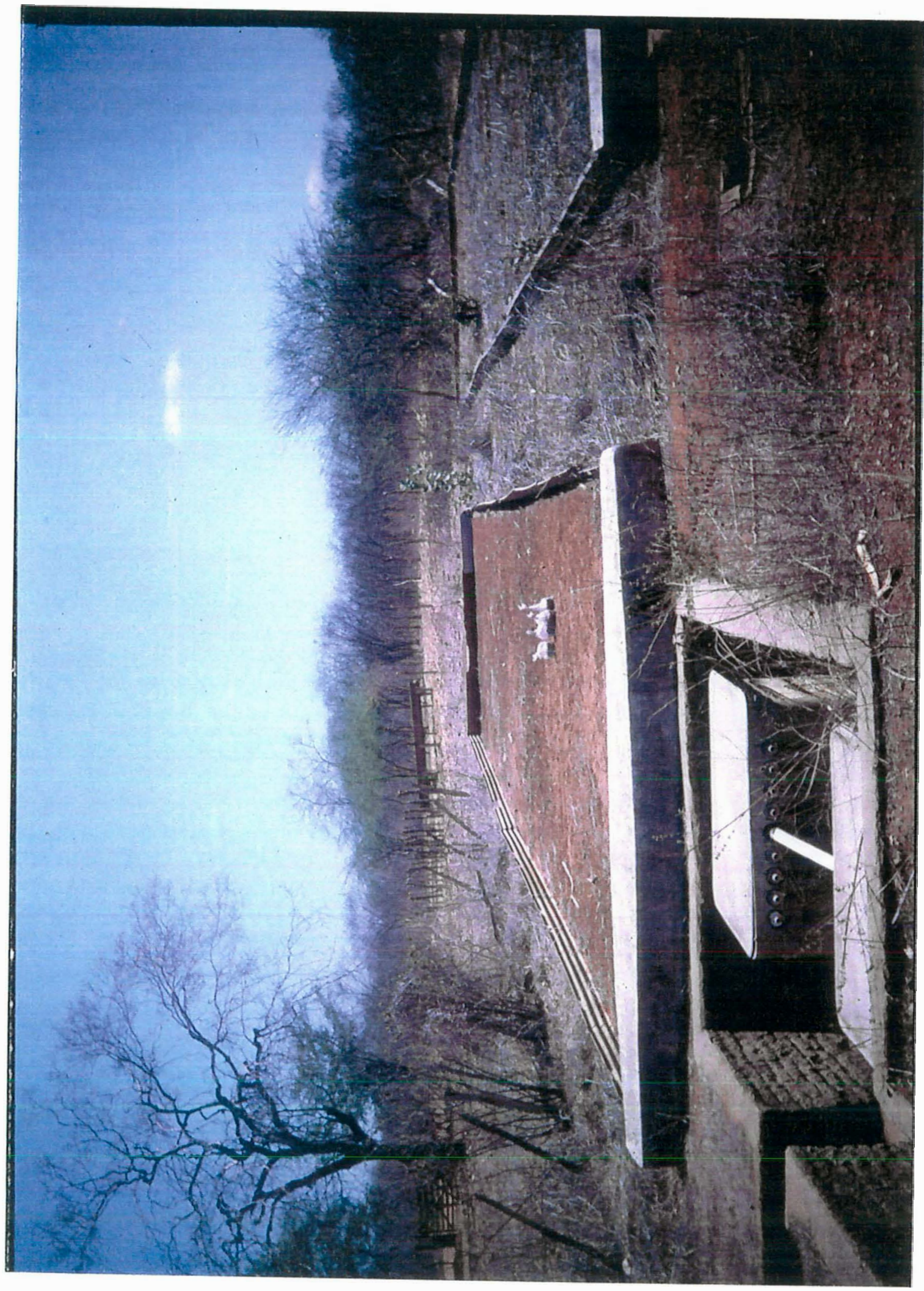

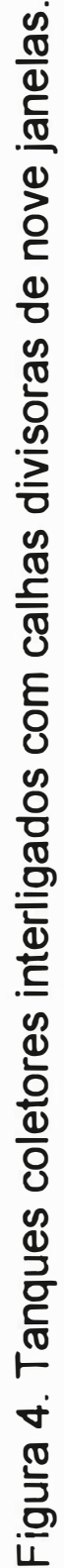


Tabela 2. Características das parcelas experimentais $(22,13 \times 4,55 \mathrm{~m})$ e $\mathrm{o}$ ano de instalação.

\begin{tabular}{lclc}
\hline $\begin{array}{l}\text { Parcelas } \\
\text { Tratamentos }\end{array}$ & $\begin{array}{c}\text { Declividade } \\
\text { media }\end{array}$ & $\begin{array}{l}\text { Cobertura } \\
\text { Vegetal }\end{array}$ & $\begin{array}{c}\text { Ano de } \\
\text { Instalação }\end{array}$ \\
\hline & $(8)$ & & \\
Dm & 3,8 & desmatada & 1982 \\
Cm & 3,9 & cobertura morta & 1982 \\
Cm & 7,2 & cobertura morta & 1982 \\
Dm & 7,0 & desmatada & 1982 \\
CaNa & 9,5 & caatinga nativa & 1982 \\
Pma & 4,0 & palma morro abaixo & 1983 \\
PCn & 4,0 & palma em contorno & 1983 \\
W & 4,0 & descoberta & 1986 \\
CaNo & 4,0 & caatinga nova & 1986 \\
& & & \\
\hline
\end{tabular}

\subsection{Critérios utilizados para separar chuvas erosivas}

Os critérios adotados para separar as chuvas erosivas baseou-se naqueles propostos por Wischmeier (1958) e modificados por Cabeda (1976). Os critérios utilizados foram os seguintes:

a) considerou-se como erosivas, precipitações que apresentaram altura igual ou superior $10,0 \mathrm{~mm}$,

b) considerou-se como erosivas as precipitações que apresentarem altura menor do que $10,0 \mathrm{~mm}$, mas tendo em 15 minutos uma precipitação igual ou superior a $6 \mathrm{~mm}$. 
Para o cálculo do Fator " $R$ " da equação universal de perdas de solo, foram utilizados os critérios proposto por Wischmeier \& Smith (1978), onde foram analisadas 255 chuvas individuais, correspondentes ao período de 1983 a 1990. Após a análise das 255 chuvas, foi contatado que 155 chuvas foram classificadas como erosivas e 100 chuvas foram classificadas como não erosivas. Para o estabelecimento das correlações entre as perdas de terra e os parâmetros erosividade da chuva, da enxurrada e da chuvaenxurrada, foram analisados 136 chuvas individuais de dados pluviográficos no período de 26.02.86 a 19.10.90. Das 136 chuvas analisadas 75 foram classificadas como chuvas erosivas e 61 foram classificadas como não erosivas.

\subsection{Determinação dos segmentos de intensidade uniforme das chuvas erosivas}

Atendido os critérios acima estabelecidos, procedeu-se a análise dos registros pluviográficos, procedendo-se a separação com a marca de um lápis no pluviograma das seções da curva com aclive uniforme, ou seja, segmentos de chuva com intensidade constante.

\subsection{Digitalização dos pontos de inflexão da intensidade da chuva}

Após a cotação e anotação dos pontos de inflexão das intensidades constante de cada chuva erosiva, as mesmas foram digitalizadas em microcomputador 486AT, onde foi utilizada a linguagem de programação FORTRAN, para o cálculo dos parâmetros erosividade da chuva, da enxurrada e chuva-enxurrada segundo as recomendações de Cataneo et al. (1982). 


\subsection{Determinação dos parâmetros erosividade da chuva e da enxurrada}

Após a cotação dos pluviogramas das chuvas individuais erosivas e digitalização dos pontos de inflexão, foram determinados os parâmetros erosividade da chuva.

Utilizando-se o programa computacional de Cataneo et al. (1982) foram determinados 59 parâmetros erosividade da chuva, que foram correlacionados com as perdas de terra da parcela em condições de alqueive contínuo, objetivando determinar os melhores preditores das perdas de terra por erosão.

Os parâmetros erosividade da chuva são a seguir descritos: a) Volume total de chuva ( $\mathrm{Vr}$ ) em mm; b) intensidades máximas ( $\mathrm{ln}$ ) ocorridas nos tempos de $5 ; 10 ; 15 ; 20 ; 25 ; 30 ; 35 ; 40 ; 45 ; 50 ; 55 ; 60$ e 120 minutos respectivamente em $\mathrm{mm} / \mathrm{h} ; \mathrm{c}$ ) energia cinética total, através dos métodos de Wischmeier \& Smith (1978) e Wagner \& Massambani (1988), ou seja, (Ec e EcW) em MJ/ha; d) somatório da energia cinética de intensidades maiores do que $10 \mathrm{~mm} / \mathrm{h}$ (Ec> 10 e EcW>10) em MJ/ha; e) somatório da energia cinética de intensidades maiores do que $25 \mathrm{~mm} / \mathrm{h}$ (Ec>25 e EcW>25) em MJ/há; f) produtos da energia cinética total pelas intensidades máximas de chuva em intervalos crescentes de tempo, através dos métodos de Wischmeier \& Smith (1978) e Wagner \& Massambani (1988), ou seja: El5, El10; $\mathrm{El}_{15} ; \mathrm{El}_{20}$; $\mathrm{El}_{25} ; \mathrm{El}_{30} ; \mathrm{El}_{35} ; \mathrm{El}_{40} ; \mathrm{El}_{45} ; \mathrm{El}_{50} ; \mathrm{El}_{55} ; \mathrm{El}_{60} ; \mathrm{El}_{120} ; \mathrm{EWI}_{5} ; \mathrm{EWI}_{10} ; \mathrm{EWI}_{15}$; $\mathrm{EWI}_{20} ; \mathrm{EWI}_{25} ; \mathrm{EWI}_{30} ; \mathrm{EWI}_{35} ; \mathrm{EWI}_{40} ; \mathrm{EWI}_{45} ; \mathrm{EWI}_{50} ; \mathrm{EWI}_{55} ; \mathrm{EWl}_{60}$ e $\mathrm{EWI}_{120} \mathrm{em} \mathrm{MJ.mm/ha.h} \mathrm{(Eln} \mathrm{e} \mathrm{EWI}$ ) e g) produtos do volume total de chuva pelas intensidades máximas das chuvas em intervalos crescentes de tempo $\left(\mathrm{Vrl}_{n}\right)$, ou seja: $\mathrm{Vrl}_{5}, \mathrm{Vrl}_{10}, \mathrm{Vrl}_{15} ; \mathrm{Vrl}_{20} ; \mathrm{Vrl}_{25} ; \mathrm{Vrl}_{30}$; $\mathrm{Vrl}_{35} \mathrm{Vrl}_{40} ; \mathrm{Vrl}_{45} ; \mathrm{Vrl}_{50}$; $\mathrm{Vrl}_{55}$; $\mathrm{Vrl}_{60}$ e $\mathrm{Vrl}_{120} \mathrm{em} \mathrm{mm}^{2} / \mathrm{h}$. 


\subsubsection{Energia cinética total (Ec e EcW)}

O método utilizado para o cálculo da energia cinética total das chuvas individuais erosivas, seguiu o procedimento descrito por Wischmeier \& Smith (1958), como a seguir é mencionado:

a) calculou-se a energia cinética em MJ/ha.mm, referentes a intensidade $(\mathrm{mm} / \mathrm{h})$ de cada segmento de intensidade constante, através da equação (2), expressa no Sistema Internacional de Unidades por Foster et al. (1981):

$$
E C=0,119+0,0873 \log I \text {, }
$$

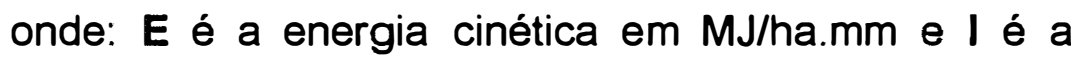
intensidade de cada segmento com intensidade constante $(\mathrm{mm} / \mathrm{h})$, sendo que para valores da energia cinética correspondente a intensidades iguais ou superiores a $76 \mathrm{~mm} / \mathrm{h}$, a energia cinética passa a ter um valor máximo de $0,2832 \mathrm{MJ} / \mathrm{ha}$;

b) multiplicou-se a energia cinética em $\mathrm{MJ} /$ ha.mm de cada segmento com intensidade constante, pela quantidade de chuva, dos respectivos segmentos para se obter a energia cinética de cada incremento de chuva em MJ/ha;

c) somou-se os valores da energia cinética em MJ/ha de todos os segmentos de chuva com intensidade constante, para obter-se a energia cinética total da chuva.

Para efeito comparativo foi também utilizada a equação da energia cinética proposta por Wagner \& Massambani (1988), expressa pela equação (3), abaixo discriminada:

$$
\mathrm{EcW}=0,153+0,0645 \log \mathrm{I}
$$


onde: E é a energia cinética da chuva (MJ/ha.mm) e l é a intensidade da chuva $(\mathrm{mm} / \mathrm{h})$.

\subsubsection{Energia cinética de segmentos de chuva com intensidade constante igual ou maior do que 10 e $25 \mathrm{~mm} / \mathrm{h}$ (Ec>10; $E c W>10 ; E c>25$ e EcW>25)}

O cálculo do parâmetro erosividade da chuva Ec>n foi determinado tomando como base a metodologia desenvolvida por Hudson (1981).

Os parâmetros erosividade da chuva Ec $>25$ e EcW $>25$ de cada chuva individual erosiva foram calculados a partir da soma dos valores da energia cinética, concernentes a segmentos de intensidade constante, igual ou superior a $25 \mathrm{~mm} / \mathrm{h}$.

Os parâmetros erosividade Ec>10 e EcW>10, de cada chuva individual erosiva foram calculados através da soma dos valores da energia cinética, relativas a segmentos de intensidade constante, igual ou superior a $10 \mathrm{~mm}$ (Carvalho, 1992).

Portanto, os parâmetros Ec $>10$ e Ec $>25$ originaram-se da aplicação da equação (2) de Wischmeier \& Smith (1978), assim como os índices EcW>10 e Ec>25 da aplicação da equação (3) de Wagner \& Massambani (1988).

\subsubsection{Produto da energia cinética total pelas intensidades máximas $(E \ln$ e EWIn)}

Os parâmetros da chuva Eln e EIW $\mathrm{n}$, respectivamente, foram calculados de acordo com a metodologia proposta por Wischmeier 
(1958). O produto da energia cinética total pelas intensidades máximas pode ser expresso matematicamente pela seguinte equação:

$$
E I_{n}=E c . I_{n}, \ldots \ldots \ldots \ldots \ldots \ldots \text { (36) }
$$

onde: Eln é o produto da energia cinética total pelas intensidades máximas em MJ.mm/ha.h; In são as intensidades máximas em intervalos crescentes de tempo, ou seja: $5,10,15,20,25,3035,40,45,50,55$, 60 e 120 minutos respectivamente em $\mathrm{mm} / \mathrm{h}$ e Ec é a energia cinética total em MJ/ha.

Da mesma forma, o parâmetro Ewl foi resultado do produto da EcW da equação (3) pelo 130.

\subsubsection{Produto do volume de chuva pelas intensidades máximas $\left(V_{\mathbf{r}} \cdot l_{\mathbf{n}}\right)$}

Os parâmetros da chuva $\mathrm{V}_{\mathrm{r}} \mathrm{n}$, foram calculados de acordo com a metodologia proposta por Lal (1976). Efetuou-se o produto do volume de chuva para cada chuva individual erosiva pelas intensidades máximas em intervalos crescentes, ou seja: $5,10,15,20,25,3035,40,45,50$, 55,60 e 120 minutos respectivamente.

$$
\operatorname{VrI}_{n}=\operatorname{Vr} \cdot I_{n} \ldots \ldots \ldots \ldots \ldots \ldots
$$

Onde: Vrln é o produto do volume de chuva $(\mathrm{Vr})$ pelas intensidades máximas em intervalos crescentes $(\ln )$; $\mathrm{Vr}$ é o volume total de chuva em mm e In são as intensidades máximas em intervalos crescentes em $\mathrm{mm} / \mathrm{h}$. 


\subsubsection{Volume de enxurrada $\left(V_{u}\right)$}

O volume de enxurrada foi o único parâmetro que não calculado através do programa de Catâneo et al (1982) sendo obtido diretamente dos tanques coletores da parcela em alqueive contínuo.

\subsection{Correção das perdas de terra da parcela descoberta para as condições da parcela padrão}

As coletas dos dados de perdas de terra e água da parcela descoberta e cultivada continuamente, corresponderam ao período de 26.02.86 a 19.10 .90 .

A correção das perdas de terra da parcela descoberta (4\%) para o declive da parcela padrão $(9 \%)$ foi feita utilizando-se a equação abaixo, proposta por Bertoni \& Lombardi Neto (1985):

$$
A=0,00984 . s^{1,18} \cdot L^{0,63}, \ldots
$$

onde: A é a perda de terra em $\mathrm{Kg}$ por unidade de largura; $S$ é o grau de declive em porcentagem e $L$ é o comprimento de rampa em metros.

A transformação direta das perdas de terra da parcela descoberta $(4,0 \%)$ para as condições de declive da parcela padrão $(9 \%)$, foi realizada utilizando-se a seguinte equação:

$$
A_{1}=2,603 \times A_{2} \ldots \ldots \ldots \ldots \ldots \ldots
$$


onde: $A_{1}$ é a perda de terra de uma chuva em kg/largura para o declive de $9,0 \%$, concernente a parcela padrão e $\mathbf{A 2}$ é a perda de terra de uma chuva em $\mathrm{kg} / \mathrm{largura}$ para o declive de $4 \%$ da parcela em alqueive contínuo.

A título de exemplo, será apresentada a dedução da equação final para a correção das perdas de terra da parcela descoberta $(4,0 \%)$, para as condições de declive da parcela padrão como é demonstrada a seguir:.

$$
\begin{aligned}
& \mathrm{A}_{1}=0,00984 \cdot 98^{1,18} \cdot 22,13 \mathrm{~m}^{0}, 63, \\
& \mathrm{~A}_{1}=0,924, \\
& \mathrm{~A}_{2}=0,00984 \cdot 48^{1,18} \cdot 22,13 \mathrm{~m}^{0,63}, \\
& \mathrm{~A}_{2}=0,355, \\
& \mathrm{~A}_{1} / \mathrm{A}_{2}=0,924 / 0,355=\mathrm{A}_{1} / \mathrm{A}_{2}=2,603 \\
& \mathrm{~A}_{1}=2,603 \times \mathrm{A}_{2}
\end{aligned}
$$

onde: $A_{1}$ é a perda de terra de uma chuva em $\mathrm{kg} / \mathrm{largura}$ para o declive de 9,0, concernente a parcela padrão e A2 é a perda de terra de uma chuva em $\mathrm{kg} / \mathrm{largura}$ para 0 declive de $4 \%$ da parcela descoberta em alqueive contínuo.

\subsection{Determinação das perdas de terra e água das microbacias experimentais}

A coleta de perda de terra e água foram realizadas diariamente na medida em que ocorreram chuvas que provocaram perdas de terra e água.

O volume total escoado foi calculado pela soma do que passa pelo vertedor e aquele que fica retido na fossa. A avaliação da produção 
total de perda de terra da bacia foi baseada em amostragem realizada no material retido na fossa (em suspensão e depositado no fundo) e no volume de enxurrada. A amostragem dos sedimentos retidos na fossa é realizada em três estágios. A concentração média obtida pela média das amostras em cada estágio é relacionada a um volume de enxurrada correspondente. Dois orifícios situados ao lado do vertedor e em alturas diferentes sifonam uma pequena parte da mistura de água-sedimento que passa pelo vertedor, acumulando-a em dois recipientes coletores que fornecem duas amostras.. A concentração média das amostras é associada ao volume de enxurrada escoado. O volume total de água escoado é calculado pela soma do que passa pelo vertedor e aquele que fica retido na fossa. (Cadier et al., 1983).

\subsection{Determinação das perdas de terra e água das parcelas experimentais}

A coleta de perdas de terra e água nas parcelas experimentais foram realizadas diariamente toda vez que ocorreram chuvas que provocaram perdas de terra e água.

Os tanques foram pré-calibrados, de modo que a amostragem de cada estágio é associada a um volume conhecido. A produção total de sedimentos é estimada pelo somatório da produção avaliada para cada estágio

O cálculo do volume total de água escoado, é a soma do conteúdo do primeiro tanque e nove vezes o volume escoado do segundo tanque.

No primeiro tanque foi colocado um balde para captar o escoamento provenientes das pequenas chuvas, facilitando a medição volumétrica e a amostragem. 
A avaliação da produção de terra foi realizada através de amostragem nos dois tanques. As amostras são coletadas no primeiro tanque, em dois estágios correspondentes a diferentes concentrações, e no segundo tanque num único estágio.

\subsection{Manejo das microbacias e das parcelas experimentais}

Para efeitos de comparação, as mesmas condições de manejo do solo e vegetação foram mantidas nas microbacias e parcelas experimentais desmatadas, ou seja, a vegetação foi removida com enxada quando atingia a altura de $5 \mathrm{~cm}$ em média.

Também para efeito de comparação, as mesmas condições de manejo do solo e vegetação foram mantidas nas microbacias e na parcela com caatinga nativa, ou seja, não sofreram qualquer intervenção de manejo de solo e vegetação.

As parcelas com cobertura morta foram roçadas quando a vegetação atingia a altura de 20 a $25 \mathrm{~cm}$, sem retirá-la de dentro das parcelas, objetivando a formação de uma cobertura morta.

As parcelas com palma forrageira foram cultivadas morro abaixo e em nível respectivamente, sendo que ambas as parcelas eram limpas quando a vegetação atingia $5 \mathrm{~cm}$ de altura.

O manejo da parcela descoberta e em alqueive contínuo seguiu as recomendações de Wischmeier \& Smith (1978), ou seja, a parcela foi mantida sem cobertura vegetal através do preparo e cultivo do solo com enxada no sentido do declive.

Com o objetivo de estudar outras culturas; em 1989, antes do início da estação chuvosa, foi retirada a palma forrageira das parcelas cultivadas morro abaixo e em nível respectivamente. Em seu lugar, 
no início das primeiras chuvas de 1989 , foram plantados milho e feijão nas respectivas parcelas.

Entretanto, devido as severas condições climáticas do ano de 1989, o milho e o feijão não conseguiram germinar, havendo perda total das culturas, ficando os anos posteriores apenas com as parcelas descobertas.

\subsection{Análise estatística dos parâmetros erosividade da chuva versus as perdas de terra}

As análises de regressão entre os parâmetros erosividade da chuva e as perdas de terra para as condições da parcela padrão, foram realizadas através do programa computacional SAS INSTITUTE (1988).

Os parâmetros erosividade da chuva foram considerados para fins dos estudos de análise de regressão, como sendo as variáveis independentes, enquanto que a perda de terra para as condições da parcela padrão (Mg/ha) foi considerada como sendo a variável dependente.

Foram calculadas as equações de regressão linear simples, o coeficiente linear (a), o coeficiente de regressão (b), entre os parâmetros erosividade da chuva e as perdas de terra.

A verificação da homogeneidade entre os coeficientes de correlação foi realizada através do teste de homogeneidade proposto por Graybill (1961), onde os coeficientes de correlação foram testados dois a dois de acordo com a seguinte equação:

$$
\mathrm{Z}=\sum_{i=1}^{2}\left(\mathrm{n}_{i}-3\right) \mathrm{Z}_{i}^{2}-(\overline{\mathrm{Z}})^{2} \sum_{i=1}^{2}\left(\mathrm{n}_{i}-3\right)_{i} \ldots \ldots
$$


onde,

$$
\mathrm{Z}_{\mathrm{i}}=\text { arco tangente hiperbólico de }\left(\mathrm{r}_{\mathrm{i}}\right) \text {; }
$$

e,

$$
\bar{Z}=\frac{\sum_{i=1}^{2}\left(n_{i}-3\right) z i}{\sum_{i=1}^{2}\left(n_{i}-3\right)} \text {, }
$$

onde: $\mathbf{Z}$ é o teste de homogeneidade e $\boldsymbol{n}_{\mathrm{i}}$ : tamanho da amostra que originou o coeficiente de correlação $\left(\mathbf{r}_{\mathbf{i}}\right)$

\subsection{Determinação dos parâmetros erosividade da chuva, da enxurrada e da chuva-enxurrada}

Foram propostos 17 modelos matemáticos envolvendo parâmetros erosividade da chuva, enxurrada e chuva enxurrada (Tabela 3), objetivando identificar, através da análise estatística, quais destes modelos poderiam explicar de forma satisfatória as perdas de terra através dos parâmetros erosividade da chuva, enxurrada e chuva-enxurrada.

Os modelos matemáticos utilizados tiveram como base os trabalhos desenvolvidos por Lombardi Neto (1979); Foster et al., (1982) e Carvalho (1992).

\subsection{Análise estatística dos parâmetros erosividade da chuva, da enxurrada e da chuva-enxurrada versus as perdas de terra}

A análise de regressão linear simples, não linear simples e de regressão linear múltipla, entre os parâmetros erosividade da 
chuva, enxurrada e chuva-enxurrada versus as perdas de terra nas condições da parcela padrão, foram realizadas, através do programa computacional SAS INSTITUTE(1988).

Tabela 3. Equações de regressão linear simples, não linear e linear múltipla, envolvendo os parâmetros erosividade da chuva, da enxurrada e chuva-enxurrada.

\begin{tabular}{|c|c|}
\hline NÚMERO & EQUAÇÕES \\
\hline DE ORDEM & \\
\hline 01 & $\mathbf{A}=\mathbf{a}+\mathbf{b} . \mathbf{E I A}$ \\
\hline 02 & $\mathbf{A}=\mathbf{a}+\mathbf{b} . \mathbf{E I} 30+\mathbf{c . E I A}$ \\
\hline 03 & $A=a+b \cdot V_{r} \cdot(I 30)^{1,44}$ \\
\hline 04 & $A=a+b(0,119+0,0873 \log I 30) V_{t} \cdot \mathbf{I} 30$ \\
\hline 05 & $A=\mathbf{a}\left(V_{\mathbf{r}}\right)^{\mathbf{b}}$ \\
\hline 06 & $A=\mathbf{a} \cdot(\mathbf{E I} 30)^{b}$ \\
\hline 07 & $\mathbf{A}=\mathbf{a}(\mathbf{E I A})^{\mathbf{b}}$ \\
\hline 08 & $\mathbf{A}=\mathbf{a}+\mathbf{b} \cdot \mathbf{V}_{\mathbf{u}}$ \\
\hline 09 & $A=\mathbf{a}\left(\mathbf{V}_{\mathbf{u}}\right)^{\mathbf{b}}$ \\
\hline 10 & $A=\mathbf{a}\left(\mathbf{V}_{\mathbf{u} \cdot \boldsymbol{\alpha} \cdot \mathbf{I} 30)^{b}}\right.$ \\
\hline 11 & $A=\mathbf{a}\left(V_{u \cdot \alpha \cdot I 5}\right)^{b}$ \\
\hline 12 & $\mathbf{A}=\mathbf{a}+\mathbf{b} \cdot \mathbf{E} I_{30}+\mathbf{c} \cdot \mathbf{V}_{\mathbf{u}}$ \\
\hline 13 & $\mathbf{A}=\mathbf{a}+\mathbf{b} \cdot \mathbf{E I A}+\mathbf{c} \cdot \mathbf{V}_{\mathbf{u}}$ \\
\hline 14 & $A=a+b(1 / 2) E I 30+c(1 / 2) V_{u}\left(\alpha \cdot I_{30}\right)^{1 / 3}$ \\
\hline 15 & $A=a+b(1 / 2) E I_{30}+c(1 / 2) V_{u}\left(\alpha \cdot I_{5}\right)^{1 / 3}$ \\
\hline 16 & $A=a+b(E I A)+c \cdot V_{u} \cdot\left(\alpha \cdot I_{30}\right)^{1 / 3}$ \\
\hline 17 & $A=a_{.}+$b.EIA $+c \cdot V_{u} \cdot \cdot\left(\alpha \cdot I_{5}\right)^{1 / 3}$ \\
\hline
\end{tabular}

Onde: A é a estimativa da perda de terra $\mathbf{M g} / \mathrm{ha} ; \mathbf{V}_{\mathbf{u}}$ é o volume da enxurrada (mm); $V_{r}$ é o volume de chuva $(\mathrm{mm}) ; I_{5}$ e $\mathbf{I}_{30}$ são respectivamente, 
as intensidades máximas em 5 e 30 minutos $(\mathrm{mm} / \mathrm{h})$; El30 é o parâmetro erosividade da chuva (MJ.mm/ha.h); ElA é o parâmetro erosividade da chuva para o tempo da enxurrada $\left(\mathrm{mm}^{2} / \mathrm{h}\right) ; \alpha=\left(\mathrm{V}_{\mathrm{u}} \mathrm{N}_{\mathrm{r}}\right)^{1 / 2}$ (adimensional).

Portanto, foram calculadas as equações de regressão linear simples, não linear simples e de regressão múltipla e por conseguintes os coeficientes de ajustamento $a, b$ e $c$, bem como os coeficientes de determinação $\left(r^{2}\right)$. Os parâmetros erosividade e suas respectivas equações, estão na tabela 3.

\subsection{Determinação do fator erodibilidade do solo (Fator K)}

A metodologia para o cálculo do fator erodibilidade do solo foi aquela preconizada por Wischmeier \& Smith (1978), que definiram o fator erodibilidade do solo $(K)$ como sendo o incremento médio na perda de terra, para cada unidade adicionada do fator $R$, ou seja, $K=A / R$.

Segundo Wischmeier \& Smith (1978), esta condição se

dá quando os fatores $L, S, C$ e $P$ forem iguais a um. Portanto, o fator $K$, combina em um único número, os efeitos das características do solo relativos a sua capacidade de infiltração e a sua susceptibilidade em se desagregar e ser transportado pela enxurrada.

Por outro lado, Wischmeier \& Smith (1978) definiram também, que existe uma relação funcional entre as perdas de terra e o fator erosividade, que pode ser expressa pelo modelo linear simples: $A=a+b E I_{30}$, onde A é a estimativa da perda de terra (variável dependente) e El30 é o parâmetro erosividade da chuva (variável independente). Segundo autores, o fator "K" é representado pelo coeficiente de regressão "b", quando os dados obtidos são oriundos de parcela padrão. 


\title{
4 RESULTADOS E DISCUSSÃO
}

\subsection{Análise de regressão entre os parâmetros erosividade da chuva e as perdas de terra}

\begin{abstract}
$\mathrm{Na}$ tabela 4 estão apresentados para efeito de comparação em ordem decrescente, os coeficientes de correlação entre os parâmetros erosividade da chuva e as perdas de terra da parcela em condições de alqueive contínuo. Foram utilizados 75 eventos, correspondentes a chuvas individuais erosivas e suas respectivas perdas de terra, ocorridas no período de 1986 a 1990. Na tabela 4 estão registrados também as equações de regressão linear simples $(y=a+b x)$, os coeficientes lineares $(a)$ e os coeficientes de regressão (b).

Através de uma análise global, pode-se constatar que os coeficientes de correlação $(r$ ) obtidos variaram 0,5095 a 0,7527 para os parâmetros $I_{5}$ e $\mathrm{Vrl}_{25}$, sendo que as variações das perdas de terra foram explicadas entre 26 e $56 \%$.
\end{abstract}

\subsubsection{Volume de chuva (Vr)}

O volume de chuva, quando correlacionado com as perdas de terra, apresentou um coeficiente de correlação $(r)$ de 0,700 . $O$ valor do coeficiente de correlação obtido, entre o volume de chuva e perdas de terra 
Tabela 4. Coeficientes de correlação, obtidos entre os parâmetros erosividade da chuva e as perdas de terra em condições da parcela padrão.

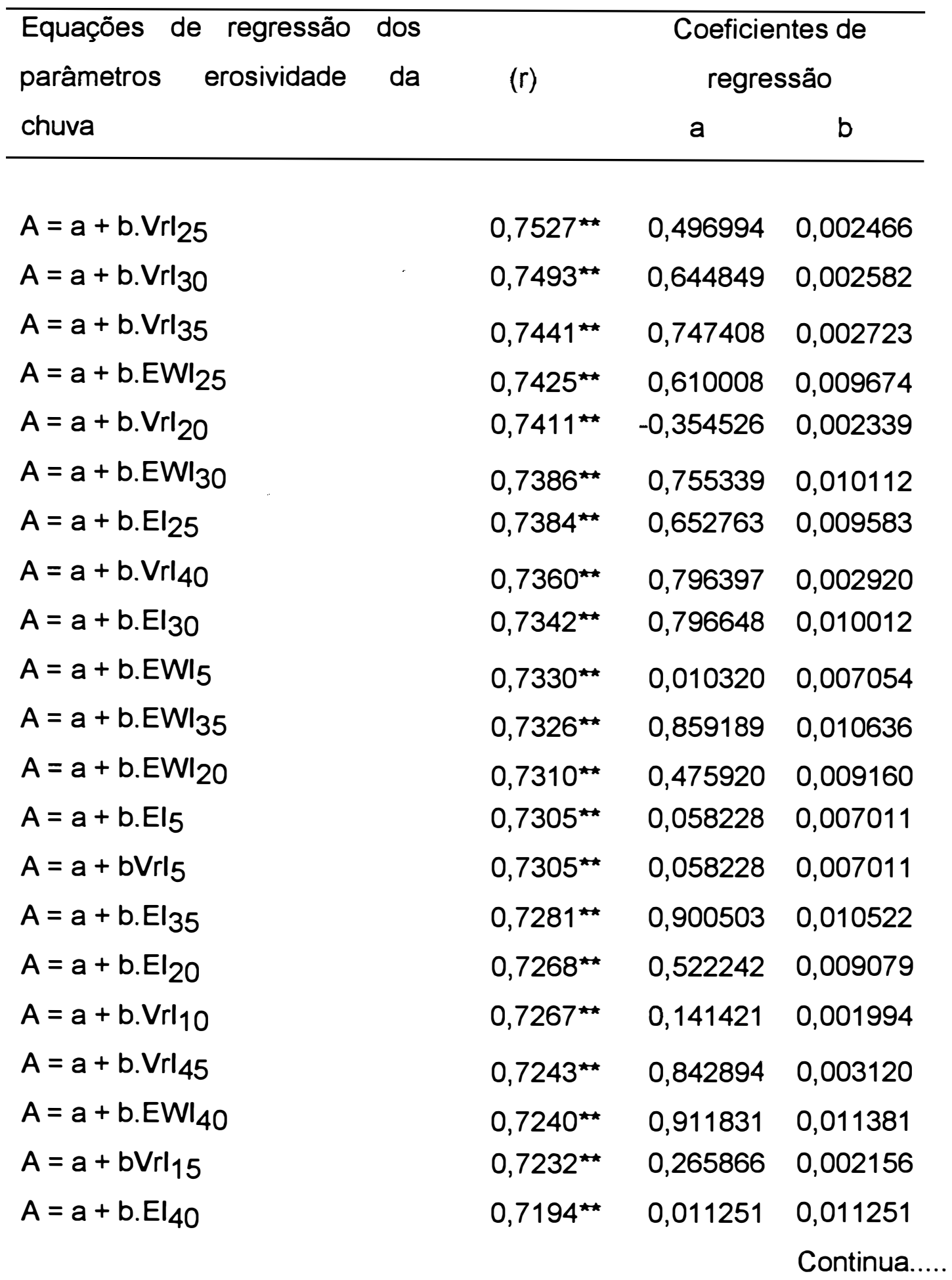


Tabela 4. Coeficientes de correlação, obtidos entre os parâmetros erosividade da chuva e as perdas de terra em condiçōes da parcela padrão.

\begin{tabular}{|c|c|c|c|}
\hline \multirow{2}{*}{$\begin{array}{l}\text { Equações de regressão dos } \\
\text { parâmetros erosividade } \\
\text { chuva }\end{array}$} & \multirow[t]{2}{*}{$(r)$} & \multicolumn{2}{|c|}{$\begin{array}{l}\text { Coeficientes de } \\
\text { regressão }\end{array}$} \\
\hline & & a & $b$ \\
\hline$A=a+b . E W l_{10}$ & $0,7186^{\star *}$ & 0,270238 & 0,007833 \\
\hline$A=a+b \cdot E I_{10}$ & $0,7149^{\star \star}$ & 0,320184 & 0,007759 \\
\hline$A=a+b \cdot E W l_{15}$ & $0,7145^{\star \star}$ & 0,389407 & 0,008463 \\
\hline$A=a+b \cdot V r l_{50}$ & $0,7126^{\star \star}$ & 0,900630 & 0,003293 \\
\hline$A=a+b \cdot E W l_{45}$ & $0,7115^{\star \star}$ & 0,964481 & 0,012120 \\
\hline$A=a+b \cdot E_{15}$ & $0,7108^{\star \star}$ & 0,937145 & 0,008382 \\
\hline$A=a+b \cdot E c$ & $0,7086^{\star \star}$ & $-1,670935$ & 0,795026 \\
\hline$A=a+b . E c W$ & $0,7080^{\star \star}$ & $-1,796760$ & 0,801380 \\
\hline$A=a+b \cdot E I_{45}$ & $0,7066^{\star \star}$ & 1,008664 & 0,011968 \\
\hline$A=a+b \cdot V r I_{55}$ & $0,7001^{\star \star}$ & 0,953291 & 0,004127 \\
\hline$A=a+b \cdot V r$ & $0,7001^{\star \star}$ & $-2,078019$ & 0,201064 \\
\hline$A=a+b \cdot E W I_{50}$ & $0,6990^{\star \star}$ & 1,027401 & 0,012749 \\
\hline$A=a+b .135$ & $0,6948^{\star \star}$ & $-2,156872$ & 0,204259 \\
\hline$A=a+b \cdot E I_{50}$ & $0,6937^{\star \star}$ & 1,073064 & 0,012574 \\
\hline$A=a+b .140$ & $0,6927^{\star \star}$ & $-2,145697$ & 0,223529 \\
\hline$A=a+b \cdot V r l_{120}$ & $0,6898^{\star \star}$ & 0,993441 & 0,006303 \\
\hline$A=a+b \cdot \operatorname{Vrl} 60$ & $0,6892^{\star \star}$ & 1,005077 & 0,003260 \\
\hline$A=a+b . E W I_{55}$ & $0,6864^{\star \star}$ & 1,084346 & 0,013370 \\
\hline$A=a+b \cdot I_{30}$ & $0,6858^{\star \star}$ & $-2,199417$ & 0,185794 \\
\hline$A=a+b .145$ & $0,6836^{\star \star}$ & $-2,095576$ & 0,241504 \\
\hline$A=a+b . E I_{55}$ & $0,6811^{\star \star}$ & 1,131212 & 0,013172 \\
\hline$A=a+b \cdot E W l_{120}$ & $0,6751^{\star \star}$ & 1,129878 & 0,024285 \\
\hline$A=a+b .150$ & $0,6748^{\star \star}$ & $-2,007091$ & 0,257442 \\
\hline
\end{tabular}

Continua... 
Tabela 4. Coeficientes de correlação, obtidos entre os parâmetros erosividade da chuva e as perdas de terra em condições da parcela padrão.

\begin{tabular}{|c|c|c|c|}
\hline \multirow{2}{*}{$\begin{array}{l}\text { Equações de regressão dos } \\
\text { parâmetros erosividade da } \\
\text { chuva }\end{array}$} & \multirow[t]{2}{*}{$(r)$} & \multicolumn{2}{|c|}{$\begin{array}{l}\text { Coeficientes de } \\
\text { regressão }\end{array}$} \\
\hline & & a & b \\
\hline$A=a+b \cdot E W l_{60}$ & $0,6741^{\star \star}$ & 1,139625 & 0,013950 \\
\hline$A=a+b \cdot E l_{120}$ & $0,6697^{\star \star}$ & 1,178387 & 0,023913 \\
\hline$A=a+b \cdot E c>10$ & $0,6692^{\star \star}$ & $-0,819960$ & 0,806670 \\
\hline$A=a+b \cdot K E W>10$ & $0,6688^{\star \star}$ & $-0,867131$ & 0,823416 \\
\hline$A=a+b \cdot E_{60}$ & $0,6685^{\star \star}$ & 1,187438 & 0,013730 \\
\hline$A=a+b . l_{25}$ & $0,6634^{\star \star}$ & $-2,201500$ & 0,165280 \\
\hline$A=a+b .155$ & $0,6625^{\star \star}$ & $-1,888327$ & 0,271182 \\
\hline$A=a+b . E c>25$ & $0,6598^{\star \star}$ & 0,062345 & 0,857348 \\
\hline$A=a+b . E c W>25$ & $0,6594^{\star \star}$ & 0,057433 & 0,836623 \\
\hline$A=a+b \cdot l_{120}$ & $0,6533^{\star \star}$ & $-1,856627$ & 0,503404 \\
\hline$A=a+b . I_{60}$ & $0,6497^{\star \star}$ & $-1,761502$ & 0,283504 \\
\hline$A=a+b \cdot l_{20}$ & $0,6168^{\star \star}$ & $-1,943254$ & 0,139271 \\
\hline$A=a+b . I_{15}$ & $0,5646^{\star \star}$ & $-1,604962$ & 0,114169 \\
\hline$A=a+b . I_{10}$ & $0,5469^{\star \star}$ & $-1,560792$ & 0,098391 \\
\hline$A=a+b .15$ & $0,5095^{\star \star}$ & $-1,509093$ & 0,078413 \\
\hline
\end{tabular}


foi em termos absolutos maior do que os obtidos no Rio Grande do Sul $(0,547$ a $0,631)$ por Morais (1986), em Campinas-SP ( $r=0,4126)$ em Mococa-SP ( $r=$ $0,4202)$ e em Pindorama SP $(r=0,2469)$ por Carvalho (19880 e em Caruaru$\mathrm{PE},(r=0,310)$ por Albuquerque et al. (1994).

A análise de regressão indicou que o volume de chuva isoladamente, explicou apenas $49 \%$ da variação das perdas de terra, indicando a necessidade da combinação de outros parâmetros associados ao volume de chuva, como já foi demonstrado, através de vários trabalhos científicos (Foster et al., 1982; Carvalho, 1992 e Albuquerque et al., 1994). Os resultados obtidos neste trabalho para o parâmetro $\mathrm{Vrl} n$, revelam este fato, ou seja, quando o $\mathrm{Vr}$ foi associado aos parâmetros $I_{n}$, houve uma melhora na estimativa das perdas de terra, ou seja as perdas de terra foram explicadas entre $47 \%$ e $56 \%$.

0 valor do coeficiente de correlação obtido para o parâmetro $\mathrm{Vr}$ foi superior aos dos parâmetros $\mathrm{Ec}>25$ ( $r=0,6598)$, $\mathrm{EcW}>25$ $(r=0,6594), E c>10(r=0,6692)$ e EcW>10 ( $r=0,6688)$, respectivamente. Entretanto inferiores aos dos parâmetros $\mathrm{Vrl}_{30}(r=0,7493), \mathrm{I}_{30}(r=0,7342)$, $\operatorname{Ec}(r=0,7086)$ e EcW $(r=0,7080)$.

\subsubsection{Intensidades máximas $\left(I_{n}\right)$}

Os parâmetros intensidades máximas da chuva $\left(I_{n}\right)$, apresentaram coeficientes de correlação que variaram de 0,5095 a 0,6948, sendo que as variações das perdas de terra foram explicadas entre $26 \%$ a $48 \%$.

Em termos absolutos a intensidade máxima em 35 minutos, quando comparada com as demais intensidades, foi a que melhor se correlacionou com as perdas de terra de Sumé-PB. A intensidade máxima em 35 minutos $\left(I_{35}\right)$, apresentou um coeficiente de correlação $(r=0,6948)$, maior 
do que os coeficientes de correlações obtidos para os parâmetros: Ec>10 ( $r=0,6692), E c W>10(r=0,6598), E c>25(r=0,6598)$ e EcW $>25(r=0,6598)$,

0 coeficiente de correlação obtido para o parâmetro da chuva 135 , foi maior do que os obtidos em Campinas-SP $(r=0,6057)$, em Mococa-SP $(r=0,6944)$ e em Pindorama-SP $(r=0,5819)$ por Carvalho (1992), no Rio grande do Sul $(r=0,663)$ por Morais (1986).

$O$ fato da intensidade da chuva em 35 minutos (135) ter apresentado em termos absolutos, o melhor coeficiente de correlação quando comparada com as demais intensidades máximas, é uma indicação de que para as condições edafoclimáticas de Sumé-PB, e especificamente do local do experimento, com solo do tipo B textural, com delgado horizonte superficial e de drenagem moderada, as perdas de terra estiveram mais associadas a chuvas de curta duração, condição em que a infiltração do solo diminui rapidamente, aumentando o escoamento superficial.

\subsubsection{Energia cinética: Ec, EcW, Ec>10, EcW>10, Ec>25 e EcW>25}

A energia cinética total representada pelos parâmetros $(E c W)$ e (Ec) apresentaram coeficientes de correlação ( $r$ ) de 0,7080 e 0,7086 respectivamente. Os coeficientes de correlação obtido para a energia cinética total neste trabalho, foram maiores que o obtido em Campinas-SP $(r=0,6696$ e 0,6769) e em Pindorama-SP ( $r=0,5267$ e 0,5358) por Carvalho (1992), no Rio Grande do Sul ( $r=0,576$ a 0,718) por Morais (1986) e semelhantes aos obtidos em Mococa-SP ( $r=0,6984$ e 0,7148), por Carvalho (1992).

A energia cinética calculada a partir da equação de Wischmeier \& Smith (1978) e da equação de Wagner \& Massambani (1988), apresentaram coeficientes de correlação praticamente iguais $(r=0,7086$ e 0,7080 ). Na tabela 4 pode-se observar também que os coeficientes lineares e os coeficientes de regressão obtidos, foram semelhantes para as respectivas 
equações, indicando que a estimativa das perdas de terra será semelhante para ambas as equações.

O resultado obtido $(r=0,708)$ para a energia cinética (Ec) neste trabalho foi menor que o resultado obtidos no E.U.A $(r=0,98)$ por Wischmeier \& Smith (1958). A ausência de um alto coeficiente de correlação para a relação entre a energia cinética e as perdas de terra, é uma indicação da necessidade de se desenvolver trabalhos de pesquisa, objetivando obter-se modelos mais ajustados às condições locais, capazes de expressar melhor a relação entre distribuição de tamanho de gotas de chuva, intensidade e energia cinética.

O coeficiente de correlação da energia cinética total (Ec) obtido neste trabalho, pode ser explicado quando se considera o fato de que a equação de Wischmeier \& Smith (1958), que foi desenvolvida a partir das condições climáticas dos E.U.A, ao ser aplicada em condições diferentes daquelas encontradas nos E.U.A, mormente naquelas existentes em climas tropicais, não representa satisfatoriamente a relação entre energia cinética e intensidade.

Vários autores chamaram a atenção, para o fato de que a equação de Wischmeier \& Smith(1958) superestima a energia cinética, quando aplicada em outras partes do mundo (Hudson, 1973; Carter et al., 1974 e Leprun, 1984). Portanto, o emprego da equação de Wischmeier \& Smith (1958) nas diferentes regiōes edafoclimáticas do Brasil, significa considerar que as chuvas do Brasil, não somente são semelhantes aquelas dos E.U.A, como são semelhantes entre si.

Vários autores constataram que a relação entre a distribuição de tamanho de gotas de chuva, intensidade e energia cinética é diferente para diferentes condições climáticas, atribuindo estas diferenças ao tipo de chuva e a sua localização geográfica (Hudson, 1973; Carter et al., 1974 e Leprun, 1984). 
Os resultados obtidos em algumas partes do Brasil, concernente a correlação entre energia cinética e perdas de terra, revela uma significativa amplitude de variação, corroborando portanto, com a argumentação acima citada de que a relação entre a distribuição de tamanho de gotas, intensidade, energia cinética e as perda de terra é diferente para diferentes condições climáticas (Leprun, 1984 e Roth et al., 1984).

Os parâmetros erosividade da chuva do tipo: $E c>10(r=$ 0,6692), EcW $>10$ ( $r=0,6688), E c>25$ ( $r=0,6598)$ e EcW $>25(r=0,6594)$, apresentaram coeficientes de correlação semelhantes, sendo que estes resultados foram em geral menores do que os obtidos no Rio Grande do Sul ( $r$ $=0,78$ para $\circ$ Ec>10) por Morais (1986) em Campinas ( $r=0,6948$ e 0,6952 para $\circ \mathrm{EcW}>10$ e Ec>10) e em Mococa-SP ( $r=0,7687$ e $r=0,7713$ para Ec>10 e EcW>10, respectivamente) por Carvalho (1992).

Em termos absolutos, os valores dos coeficientes de correlação dos parâmetros Ec>10 ( $r=0,6692)$ e EcW>10 ( $r=0,6688)$ foram, maiores do que os obtidos para os parâmetro $\mathrm{Ec}>25(r=0,6598)$ e $E c W>25$ ( $r$ =0,6594), concordando com Carvalho (1992).

Analisando os coeficientes de correlação dos parâmetros Ec>n, pode-se constatar que a eliminação dos valores da energia cinética das intensidades inferiores a 10 e $25 \mathrm{~mm} / \mathrm{h}$, respectivamente, não melhorou a estimativa das perdas de terra, uma vez que, os valores dos coeficientes de correlação da energia cinética total ( $\mathrm{Ec}$ e EcW) foram maiores. Estes resultados discordam daqueles obtidos por Hudson (1973); Albuquerque et al. (1994) e Carvalho (1992).

Os parâmetros erosividade da chuva do tipo: $\mathrm{Ec}>10(r=$ 0,6692), EcW>10 ( $r=0,6688), E c>25(r=0,6598)$ e EcW $>25(r=0,6594)$, apresentaram coeficientes de correlação inferiores aos obtidos para os parâmetros erosividade da chuva do tipo: $\mathrm{Vrl}_{30}(r=0,7493)$ e $\mathrm{El}_{30}(r=$ 0,7342 ), respectivamente. 


\subsubsection{Produto do volume de chuva pelas intensidades máximas $\left(V_{r} \cdot \ln \right)$}

Os parâmetros erosividade da chuva $\mathrm{V}_{\mathrm{r}} \cdot \mathrm{I}_{\mathrm{n}}$, apresentaram coeficientes de correlação que variaram de 0,6892 a 0,7527, para os parâmetros $\mathrm{V}_{\mathrm{r}} \mathrm{l}_{25}$ e $\mathrm{V}_{\mathrm{r}} \mathrm{l}_{60}$ respectivamente, sendo que as variações das perdas de terra foram explicadas entre $47 \%$ a $56 \%$.

Comparando-se entre si os valores dos coeficientes de correlação do parâmetro $\mathrm{V}_{\mathrm{r}} \mathrm{30}$, obtido por Morais (1986) no Rio Grande do Sul $(r=0,745)$, com o obtido em Sumé-PB $(r=0,749)$, pode-se constatar que os valores foram semelhantes.

$O$ resultado obtido para o parâmetro $\mathrm{V}_{\mathrm{r}} \mathrm{l}_{30}$, foi em geral maior que o obtido por Foster et al., (1982) para as condições climáticas dos E.U.A $(r=0,229$ a 0,788$)$.

Uma análise comparativa dos 10 melhores estimadores das perdas de terra em condições de alqueive, indicou que 5 foram do tipo $\left(V_{r} \cdot I_{n}\right)$ a saber: $V_{r} \cdot I_{25}(r=0,7527) ; V_{r} \cdot I_{30}(r=0,7493) ; V_{r} \cdot I_{35}(r=0,7441)$; $V_{r} \cdot I_{20}(r=0,7411)$ e $V_{r} \cdot I_{40}(r=0,7360)$, respectivamente.

Portanto, os parâmetros erosividade da chuva $\mathrm{V}_{\mathrm{r}} \cdot \mathrm{l}_{25}(\mathrm{r}=$ $0,7527), V_{r} \cdot l_{30}(r=0,7493)$ e $V_{r} \cdot l_{35}(r=0,7441)$ apresentaram em termos absolutos, coeficientes de correlação maiores dos que os obtidos para os parâmetros erosividade da chuva $\mathrm{El}_{25}(\mathrm{r}=0,7384), \mathrm{El}_{30}(\mathrm{r}=0,7342), \mathrm{El}_{5}(\mathrm{r}=$ $0,7305), \mathrm{KE}(r=0,7086)$ e EcW $(r=0,7080)$ respectivamente.

$\mathrm{O}$ fato de que os parâmetros da chuva $\mathrm{V}_{\mathrm{r} .} \mathrm{I}_{25}, \mathrm{~V}_{\mathrm{r} .} \mathrm{l}_{30}$, e $V_{r} .135$, terem apresentado em termos absolutos as melhores correlações com as perdas de terra, vem reforçar a argumentação anterior apresentada na discussão da intensidade máxima em 35 minutos (135), de que para as condições edafoclimáticas do local do experimento, com solo B textural, com delgado horizonte superficial e de drenagem moderada, as perdas de terra 
estão mais associadas a chuvas de curta duração, condição em que a infiltração do solo diminui rapidamente, aumentando o escoamento superficial.

Portanto, o modelo linear expresso pelo produto entre o volume de chuva e as intensidades máximas em 25, 30, e 35 minutos, respectivamente, contribuíram para melhorar a correlação com as perdas de terra, quando comparado com o modelo linear, onde o volume de chuva foi considerado isoladamente, corroborando com a premissa anterior de que havia a necessidade de se associar outro parâmetro ao volume de chuva para que se tivesse uma melhor estimativa das perdas de terra. Os resultados obtidos concordam com os obtidos por Foster et al. (1982), Carvalho (1992) e Albuquerque et al. (1994).

$O$ parâmetro erosividade da chuva $\mathrm{V}_{\mathrm{r}} \mathrm{l}_{25}$, por exigir como seus componentes, apenas o volume de chuva e as intensidade máximas, e dispensar o cálculo da energia cinética, torna-se um parâmetros de grande importância na estimativa das perdas de terra, devido a sua simplificação, mormente para aqueles locais desprovidos de maiores informações, além daqueles relativos ao volume de chuva e as intensidades máximas.

\subsubsection{Produto da energia cinética pelas intensidades máximas $\left(E I_{n}\right.$ e $\left.E W_{n}\right)$}

Os parâmetros da chuva $\mathrm{El}_{\mathrm{n}}$, apresentaram coeficientes de correlação (r) que variaram de 0,6685 a 0,7425 , para os parâmetros El60 e $\mathrm{EWI}_{25}$

Dentre os parâmetros $E W I_{n}$, o parâmetro $\mathrm{EWI}_{25}$ ( $r=$ $0,7425)$ foi o que apresentou a melhor correlação com as perdas de terra, ficando abaixo dos seguintes parâmetros: Vr.l $25(r=0,7527)$, Vr.l30 $(r=$ $0,7493)$ e Vr.135 $(r=0,7441)$. 
Em termos absolutos o parâmetro erosividade da chuva EWIn $(r=0,6741$ a 0,7425$)$, se apresentou como melhor estimador das perdas de terra do que o parâmetro do tipo $E \ln (r=0,6685$ a 0,7384).

Os dados obtidos em Campinas-SP e Pindorama-SP por Carvalho (1992), concernente aos parâmetros $E I_{n}$, foram em geral menores do que os obtidos neste trabalho ( $r=0,5405$ a 0,6791), entretanto em Mococa os valores obtidos por Carvalho (1992), foram maiores ( $r=0,7399$ a 0,7596).

Em Guaiba-RS, Morais (1986) obteve valores maiores para o parâmetro $\mathrm{El}_{30}(\mathrm{r}=0,749)$. Entretanto, $\mathrm{o}$ resultado obtido para $\circ$ parâmetro $\mathrm{El}_{30}$ neste trabalho foi maior que os obtidos em Campinas-SP ( $r$ = 0,6763) e Pindorama-SP $(r=0,6063)$ por Carvalho (1992), em Glória do Goitá $(0,7300)$ por Catalince \& Margolis (1994).

Os parâmetros $E l_{n}$, explicaram as perdas de terra entre 45 a $55 \%$, portanto inferior aos valores obtidos ( 72 a $97 \%$ ) para $\circ \mathrm{El}_{30}$ por Wischmeier \& Smith (1959).

Apesar do parâmetro erosividade da chuva $\mathrm{El}_{30}$, ter sido selecionado em clima temperado e pelas variações da energia cinética da chuva que ocorrem entre diferentes regiões, este parâmetro vem se apresentando como um razoável estimador das perdas de terra, como tem demonstrado diversos trabalhos já realizados nas condições edafoclimáticas do Brasil, sendo por isso utilizado para estimar o potencial erosivo das chuvas no Brasil e em muitos paises de clima tropical (Lombardi Neto, 1979; Morais, 1986, Carvalho 1987 e Carvalho, 1992).

\subsubsection{Análise do teste de homogeneidade}

A aplicação do teste estatístico proposto por Graybill (1961), para a verificação da significância entre os coeficiente de correlação 
(r), obtidos a partir das correlações entre os parâmetros da chuva e as perdas de terra de Sumé-PB, possibilitou os seguintes resultados:

a) não existe diferença significativa ao nível de $5 \%$ de probabilidade, entre os coeficientes de correlação dos parâmetros $\mathrm{V}_{\mathrm{r}} \mathrm{I}_{25} \mathrm{e} \mathrm{I}_{20}$. Por conseguinte não existe também diferença significativa entre os coeficientes de correlação dos seguintes parâmetros entre si: e Ec>10; Ec>10 e Ec>25; $\mathrm{V}_{\mathrm{rl}} 60$ e Ec>10; $\mathrm{V}_{\mathrm{r}} \mathrm{l} 60$ e Ec>25; Ec e Ec>10; EcW e Ec>25; $\mathrm{V}_{\mathrm{r}} \mathrm{I}_{30}$ e El $30 ; \mathrm{V}_{\mathrm{r}} \mathrm{l}_{30}$ $\mathrm{Ec} ; \mathrm{V}_{\mathrm{r}} \mathrm{l}_{30}$ e EcWe $\mathrm{El}_{30}$; e $\mathrm{EWI}_{30}$

b) não existe diferença significativa ao nível de $5 \%$ de probabilidade entre a energia cinética calculada pela equação de Wischmeier \& Smith (1978) e a equação de Wagner \& Massambani (1988), corroborando com os resultados obtidos por Carvalho (1992).

Em termos absolutos o parâmetro $\mathrm{V}_{\mathrm{r}} \mathrm{l}_{25}$ foi o que melhor se correlacionou com as perdas de terra, entretanto a não existência de significância estatística entre os coeficientes de correlação dos parâmetros $\mathrm{V}_{\mathrm{r}} \mathrm{I}_{25}$ e El 30 , torna estatisticamente o parâmetro $\mathrm{El}_{30}$ semelhante ao parâmetro $\mathrm{V}_{\mathrm{r}} / 25$, visto que as diferenças em termos absolutos são atribuídas aos efeitos do acaso. Por conseguinte, o parâmetro $\mathrm{El}_{30}$, pode estimar as perdas de terra causado pelas chuvas com mesma precisão que o parâmetro $\mathrm{V}_{\mathrm{r}} \mathrm{l} 25$.

Por outro lado, deve-se ressaltar, que os resultados obtidos através do método de Graybill (1969), devem ser interpretados com cautela, visto que, foram utilizados 75 eventos, concernente a quatro anos de precipitação pluviométrica e de perdas de terra, portanto, para que se tenha resultados mais consistentes, seria necessário uma série mais longa de eventos.

A determinação do número mínimo de anos de uma série hidrológica, que pode ser considerada como aceitável, foi obtido por Albuquerque et al. (1994), para as condições semi-áridas de Caruaru-PE. $O$ 
número mínimo de anos considerado como aceitável, foi de 20 anos. Portanto, o tamanho da amostra dos eventos pluviográficos do presente estudo pode estar subdimensionado. Este fato concorda com Wischmeier \& Smith (1978), os quais indicam que o fator $\mathrm{R}$ deveria ser obtido de uma série contínua de dados de pelo menos 20 anos. Portanto, para a região Semi-árida do Nordeste, seriam necessários experimentos de maior duração para que se pudesse consolidar os resultados obtidos.

\subsection{Análise de regressão dos parâmetros erosividade da chuva, da enxurrada e da chuva-enxurrada versus as perdas de terra.}

$\mathrm{Na}$ tabela 5 estão apresentados os coeficientes de determinação $\left(r^{2}\right)$ e os respectivos coeficientes de regressão ajustados $(a, b$ e c) das equações de regressão entre os parâmetros erosividade da chuva, da enxurrada e chuva-enxurrada e as perdas de terra da parcela em alqueive contínuo, correspondentes a 75 chuvas individuais erosivas, ocorridas em Sumé-PB no período de 1986 a 1990.

Pode-se observar na tabela 5 , que os coeficientes de determinação $\left(r^{2}\right)$ variaram de 0,3300 a 0,8729 para o parâmetro erosividade

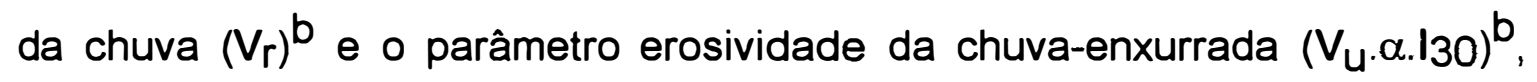
respectivamente.

Quando se considera em termos absolutos, os valores dos coeficientes de determinação, obtidos para a relação entre os parâmetros erosividade da chuva, da enxurrada e da chuva-enxurrada e as perdas de terra de Sumé-PB, constata-se que as equações de regressão linear que melhor estimaram as perdas de terra em condições de alqueive contínuo foram as equações de regressão não lineares abaixo descritas: 


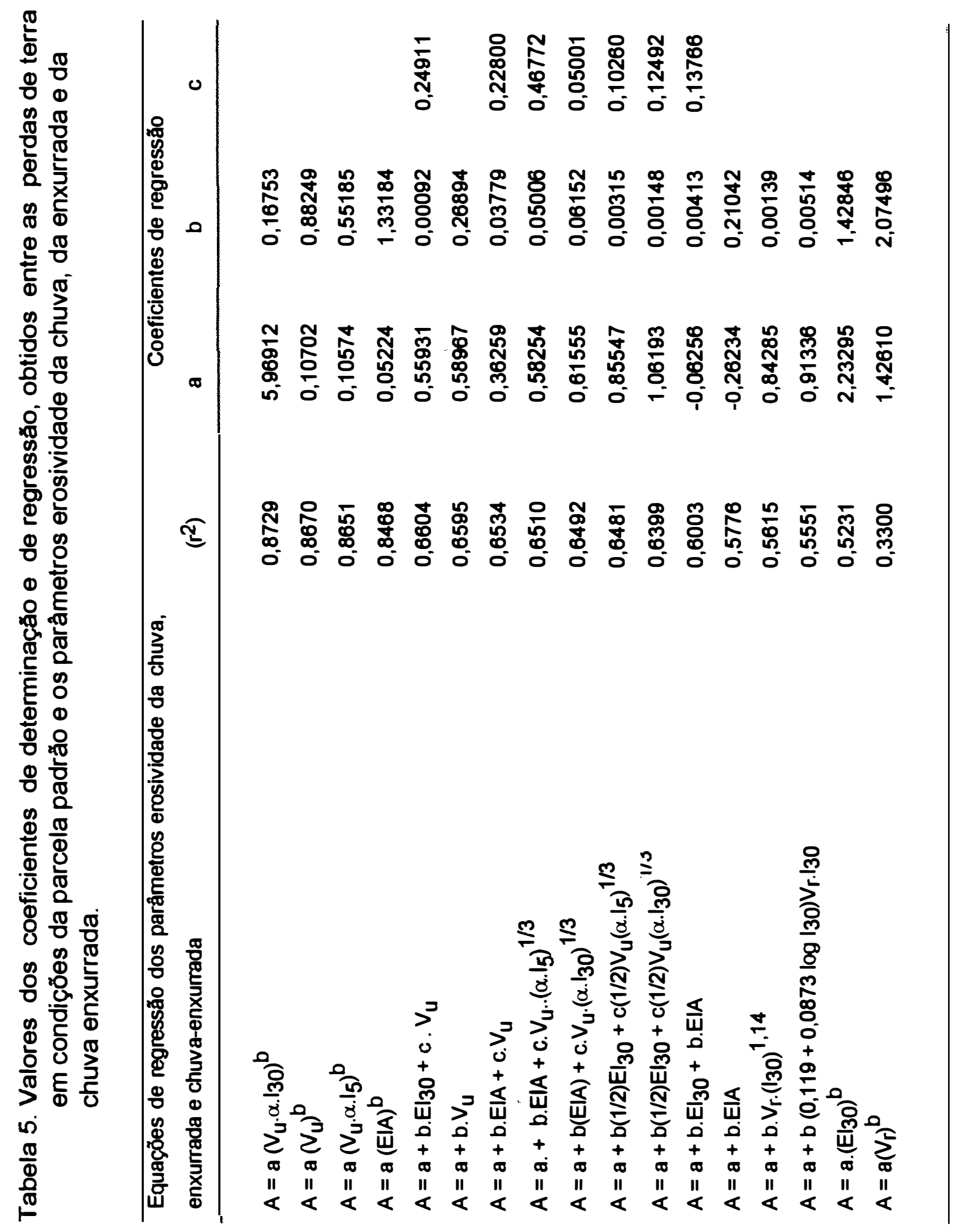




$$
\begin{array}{ll}
A=5,96912 \cdot\left(V_{u} \cdot \alpha \cdot I_{30}\right) 0,16753 & \left(r^{2}=0,8729\right) \\
A=0,10702 \cdot\left(V_{u}\right) 0,88249 & \left(r^{2}=0,8670\right) \\
A=0,10574 \cdot\left(V_{u} \cdot \alpha \cdot I_{5}\right) 0,55185 & \left(r^{2}=0,8651\right) \\
A=0,05224 \cdot(E I A) 1,33184 & \left(r^{2}=0,8468\right)
\end{array}
$$

Portanto, os resultados obtidos a partir das análises de regressão, indicam que as equações de regressão não linear acima mencionadas, quando comparados com as equações de regressão linear (Tabela 4), melhoraram significativamente a estimativa das perdas de terra da parcela em alqueive contínuo.

\subsubsection{Parâmetros erosividade da chuva}

$\mathrm{Na}$ Tabela 5 podem ser vistos os coeficientes de determinação, obtidos a partir da análise de regressão entre os parâmetros erosividade da chuva expressos por equações lineares e não lineares (lineares por anamorfose) e as perdas de terra nas condições da parcela padrão, para 75 chuvas individuais erosivas ocorridas no período de 1986 a 1990.

Os coeficientes de determinação, variaram de 0,3300 a 0,5615, para os parâmetros erosividade da chuva $(\mathrm{Vr})^{\mathrm{b}}$ e $\operatorname{Vr} .\left(\mathrm{I}_{30}\right)^{1,14}$. Portanto, os parâmetros erosividade da chuva explicaram as variações das perdas de terra entre $33 \%$ e $56 \%$.

Uma análise comparativa entre os parâmetros erosividade da chuva e os parâmetros erosividade da enxurrada e da chuvaenxurrada, pode-se constatar que os parâmetros erosividade da chuva foram os que apresentaram os mais baixos coeficientes de determinação.

Este fato vem corroborar com vários autores, que constataram que o processo erosivo entresulcos, representado pelo impacto da 
gota de chuva, possui um menor efeito sobre as perdas de terra por erosão, quando comparado com o processo erosivo dos sulcos representado pela enxurrada (Lombardi Neto, 1979; Foster et al., 1982; Meyer, 1975 e Foster e Meyer, 1975).

O modelo não linear utilizado para o parâmetro erosividade da chuva $\left(\mathrm{V}_{\mathrm{r}} \mathrm{I} / 30\right)^{1,14}$, quando comparado com os demais parâmetros erosividade da chuva, apresentou o maior coeficiente de determinação $\left(r^{2}=0,5615\right)$, explicando em $56 \%$ as variações das perdas de terra ocorridas em condições de alqueive contínuo. O modelo linear expresso pelo parâmetro $\mathrm{V}_{\mathrm{r}} \mathrm{l} 30$, também explicou em $56 \%$ as variações das perdas de terra. Portanto, o modelo não linear utilizado para o parâmetro $\left(V_{r} \cdot 130\right)^{1,14}$, não melhorou a estimativa das perdas de terra quando comparado com o modelo linear $V_{r} .130$.

Em termos absolutos, os resultados obtidos para os parâmetros erosividade da chuva $\left(r^{2}=0,3300\right.$ a 0,5615$)$ foram em geral mais baixos que aqueles obtidos nos E.U.A ( $r^{2}=0,230$ a 0,0802$)$ por Lombardi Neto (1979) e Foster et al. (1982). Entretanto, foram em geral mais altos que os obtidos para Campinas-SP $(0,4577$ a 0,5856), Mococa-SP $(0,2741$ a 0,5639) e Pindorama-SP $(0,2450$ a 0,3649) por Carvalho (1992).

A equação de regressão do parâmetro erosividade da chuva, que melhor se correlacionou com as perdas de terra está abaixo descrita:

$$
A=0,84285+0,0013 \cdot V_{r} \cdot(I 30)^{1,14}\left(r^{2}=0,5615\right)
$$

A Equação não linear utilizado para o parâmetro $\left(\mathrm{El}_{30}\right)^{\mathrm{b}}$, não melhorou a estimativa das perdas de terra $\left(r^{2}=0,5231\right)$, quando comparado ao modelo linear $\left(\mathrm{El}_{30}\right)$, que apresentou um coeficiente de determinação ligeiramente superior $\left(r^{2}=0,5391\right)$. 
O volume de chuva, quando expresso por equação não linear apresentou um coeficiente de determinação menor $\left(r^{2}=0,3300\right)$, quando comparado com o modelo linear $\left(r^{2}=0,7001\right)$. Através dos dados obtidos, pode-se constatar a não existência de uma relação não linear entre as perdas de terra e os parâmetros erosividade da chuva, como sugerido por Lombardi Neto, (1979).

\subsubsection{Parâmetros erosividade da enxurrada}

$\mathrm{Na}$ tabela 5, estão registrados os valores dos coeficientes de determinação, obtidos a partir da correlação entre os fatores erosividade da enxurrada e as perdas de terra da parcela descoberta em alqueive contínuo, para 75 chuvas individuais ocorridas no período de 1986 a 1990. Os coeficientes de determinação variaram $\left(r^{2}\right)$ de 0,6595 a 0,8670 , para os parâmetros erosividade da enxurrada $V_{u} e\left(V_{u}\right)^{b}$, respectivamente.

Em termos absolutos, o coeficiente de determinação, obtido no presente trabalho, concernente ao parâmetro erosividade da enxurrada $V_{u}$, foi em geral maior $\left(r^{2}=0,6595\right)$, do que os obtidos nos E.U.A ( $r^{2}$ $=14,4$ a 76,8) por Foster et al. (1982); em Mococa-SP $\left(r^{2}=0,6462\right)$ e Pindorama-SP $\left(r^{2}=0,4943\right)$ por Carvalho (1992), entretanto menor que os obtidos em Campinas-SP $\left(r^{2}=0,6892\right)$ por Carvalho (1992).

Com relação ao modelo não linear $\left(V_{u}\right)^{b}$, constatou-se em termos absolutos, que 0 coeficiente de determinação foi maior $\left(r^{2}=\right.$ $0,8670)$, do que os obtidos nos E.U.A ( $r^{2}=0,156$ a 0,799$)$ por Foster et al. (1982); em Campinas-SP $\left(r^{2}=0,7950\right)$, em Mococa-SP $\left(r^{2}=0,7950\right)$ e Pindorama-SP $\left(r^{2}=0,6264\right)$ por Carvalho (1992).

Portanto, em termos absolutos, o parâmetro erosividade da enxurrada que melhor se correlacionou com as perdas de terra, e sua respectiva equação de regressão foi a seguinte: 


$$
A=0,10702\left(V_{u}\right)^{0,88249} \quad\left(x^{2}=0,8670\right)
$$

Em termos absolutos o parâmetro erosividade da enxurrada $\left(r^{2}=0,8670\right)$ expresso pelo modelo não linear $\left(V_{u}\right)^{b}$, quando comparado com os demais parâmetros, apresentou o segundo melhor coeficiente de determinação, ficando apenas abaixo do parâmetro erosividade da chuva-enxurrada $\left(\mathrm{V}_{\mathrm{U}} \cdot \alpha \cdot 130\right)^{\mathrm{b}}$, por conseguinte, apresentou uma melhor precisão na estimativa das perdas de terra, do que os modelos imediatamente abaixo em ordem decrescente, utilizados para estimar os demais parâmetros erosividade da chuva e chuva-enxurrada.

O fato do parâmetro erosividade da enxurrada, ter apresentado uma melhor explicação das perdas de terra do que os parâmetros erosividade da chuva, indica que o potencial erosivo da enxurrada nos sulcos, para as condições edafoclimáticas de Sumé-PB, redunda em maiores efeitos sobre as perdas de terra do que a erosividade da chuva, representada pelo impacto das gotas de chuva, corroborando com Meyer et al. (1975); Lombardi Neto (1979); Foster et al., (1982) e Carvalho (1992).

Os resultados relativos aos parâmetros erosividade da enxurrada, obtidos neste trabalho, concordam com os obtidos por Carvalho (1992). Segundo este autor, os resultados obtidos para o parâmetro erosividade da enxurrada, sugere que em condições tropicais, provavelmente, - volume da enxurrada, seja melhor, devido aos maiores valores de intensidade das chuvas tropicais, em relação àqueles da faixa temperada do globo terrestre. Chuvas intensas proporcionam intensas enxurrada, elevando, por conseguinte, o processo de erosão nos sulcos do solo, quando comparado à erosão de impacto da chuva ou entresulcos. 
A análise dos pluviogramas e das perdas de terra deste trabalho, tornou evidente, que as principais perdas de terra, estavam associadas a poucas chuvas de alta intensidade. Eventos de aproximadamente $60,70,80,90$ e $168 \mathrm{~mm}$, que ocorreram em um único dia, proporcionaram perdas de terra que variaram de 20 a $70 \mathrm{Mg} / \mathrm{ha}$.

Em função do fato de que o parâmetro erosividade da enxurrada $\left(V_{u}\right)^{b}$, ter explicado $86,7 \%$ das variações das perdas de terra, indica que $\circ$ parâmetro erosividade da enxurrada, pode se tornar um parâmetro erosividade muito promissor. Portanto, deve-se envidar esforços no sentido de avaliar este parâmetro por um período mais longo, objetivando-se consolidar estes resultados. Os resultados indicam também que há um efeito não linear entre perdas de terra e o parâmetro erosividade da enxurrada.

Quando comparado com o volume de chuva, o volume de enxurrada, apresentou uma melhora significativa da predição das perdas de terra. Em resumo, pode-se concluir, que em geral, quando o parâmetro erosividade da enxurrada foi introduzido isoladamente ou em combinação com um parâmetro erosividade da chuva melhorou a predição das perdas de terra.

\subsubsection{Parâmetros erosividade da chuva-enxurrada}

$\mathrm{Na}$ tabela 5 estão apresentados os coeficientes de determinação, obtidos a partir das equações de regressão linear, linear múltipla e não linear entre os parâmetros erosividade da chuva-enxurrada e as perdas de terra da parcela padrão, para 75 chuvas individuais erosivas, ocorridas no período de 1986 a 1990. Os resultados obtidos para os coeficientes de determinação, variaram de 0,5776 a 0,8729, para os parâmetros erosividade da

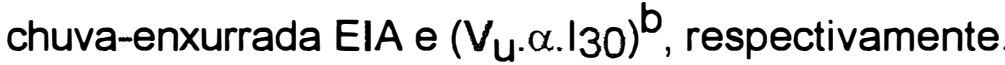




\subsubsection{Equações de regressão não linear (linear por anamorfose)}

Através dos valores apresentados na tabela 5 , podese constatar que os parâmetros erosividade da chuva-enxurrada, expressos por modelos não lineares: $(E I A)^{b},\left(V_{u} \cdot \alpha .130\right)^{b}$ e $\left(V_{u} \cdot \alpha \cdot 15\right)^{b}$, foram os que apresentaram os melhores coeficientes de determinação $\left(r^{2}=0,8468\right.$ a 0,8729), por conseguinte foram os melhores preditores das perdas de terra, quando comparado com os demais parâmetros erosividade da chuva, da enxurrada e da chuva-enxurrada. Os coeficiente de determinação $\left(r^{2}\right)$ variaram de 0,5776 a 0,8729 para os parâmetros erosividade da chuva-enxurrada (EIA) ${ }^{\mathrm{b}}$ e $\left(V_{u} \cdot \alpha \cdot 130\right)^{b}$, respectivamente.

Os resultados obtidos, permitem concluir que os parâmetros erosividade da chuva-enxurrada: $(E \mid A)^{b},\left(V_{u} \cdot \alpha \cdot 130\right)^{b}$ e $\left(V_{u} \cdot \alpha \cdot 15\right)^{b}$, expressos por modelos não lineares, apresentaram uma melhoria significativa na explicação das perdas de terra obtidos em condições de alqueive contínuo, quando comparados com os demais parâmetros erosividade da chuva, enxurrada e chuva-enxurrada expressos por modelos lineares simples, lineares múltiplos e não lineares. Os modelos acima citados explicaram os eventos relativos as perdas de terra em condições da parcela padrão na ordem de 84,7 a $87,3 \%$. Portanto, juntamente com o parâmetro erosividade da enxurrada $\left(V_{u}\right)^{b}$, os parâmetros erosividade da chuva-enxurrada do tipo: (EIA $)^{b},\left(V_{u} \cdot \alpha\right.$ $.130)^{b}$ e $\left(V_{u} \cdot \alpha .15\right)^{b}$ foram os melhores estimadores das perdas de terra em condições de alqueive em Sumé-PB.

Corroborando com os resultados obtidos neste trabalho, Lombardi Neto (1979) e Foster et al. (1980) constataram que a combinação de um fator erosividade da enxurrada, com um fator erosividade da chuva, melhorou significativamente a estimativa das perdas de terra para chuvas específicas. Os autores concluíram que os parâmetros erosividade que 
melhor estimaram as perdas de terra foram os chuva-enxurrada a saber: EIA, $\left(V_{u} \cdot \alpha \cdot 130\right)^{b}$ e $\left(V_{u} \cdot \alpha \cdot 130\right)^{1 / 3}$.

Portanto, os resultados obtidos neste trabalho para os parâmetros: $\left(V_{u} \cdot \alpha \cdot 130\right)^{b},\left(V_{u}\right)^{b}, \quad\left(V_{u} \cdot \alpha \cdot 15\right)^{b}$ e $(E \mid A)^{b}$, corroboram com a hipótese defendida por diversos autores de que havia a necessidade de se acrescentar um parâmetro erosividade da enxurrada ao fator $R$ da equação universal de perdas de solo, para que as perdas de solo fossem estimadas com maior precisão. (Dragoun, 1962; Williams et al., 1971; Williams, 1975; Foster et al., 1977a,b; Lombardi Neto, 1979 e Carvalho, 1992).

Os resultados obtidos discordam daqueles obtidos nos E.U.A por Wischmeier \& Smith (1978), que concluíram que o parâmetro erosividade que melhor estimava as perdas de terra era $\circ \mathrm{E}_{30}$. Segundo os autores o produto da energia cinética pela intensidade máxima em 30 minutos, mensura o efeito de como a erosão por impacto, salpico e turbulência se combinam com a enxurrada para transportar as partículas de solo desprendidas.

Carvalho (1992) constatou que os parâmetros erosividade da chuva-enxurrada, expressos pelos modelos não lineares do tipo: $(E I A)^{b}, \quad\left(V_{u} \cdot \alpha .130\right)^{b}$ e $\left(V_{u} \cdot \alpha .15\right)^{b}$, devido a sua simplicidade e aplicabilidade, foram os que melhor se adequaram as condições edafoclimáticas de Campinas-SP, Mococa-SP e Pindorama-SP, respectivamente, corroborando com os resultados obtidos neste traabalho.

Todavia, deve-se ressaltar que os resultados obtidos neste trabalho, para os parâmetros erosividade da chuva-enxurrada do tipo: $(E I A)^{b}, \quad\left(V_{u} \cdot \alpha \cdot 130\right)^{b}$ e $\left(V_{u} \cdot \alpha .15\right)^{b}$, foram superiores aos obtidos em CampinasSP $\left(r^{2}=0,7774\right.$ a 0,8033), em Mococa-SP $\left(r^{2}=0,7760\right.$ a 0,8106) e em Pindorama-SP $\left(r^{2}=0,6372\right.$ a 0,6584$)$ por Carvalho (1992). Os resultados obtidos, foram também em geral, superiores aos obtidos nos E.U.A, por Lombardi Neto (1979) e Foster et al. (1982). 
Para as condições tropicais do Estado de São Paulo, que as perdas de terra por erosão foram mais bem preditas por um parâmetro erosividade em que esteja incluso em sua composição variáveis combinadas da chuva $\left(V_{r}\right)$ e enxurrada $\left(V_{u}\right)$, do que por um parâmetro, que só possua variáveis da chuva como o $\mathrm{El}_{30}$, corroborando com os resultados obtidos neste trabalho.

Os resultados obtidos para os parâmetros da chuvaenxurrada expresso por equações não lineares, é explicado quando se considera a alta resposta das perdas de terra às chuvas tropicais de elevadas intensidades. Este fato ocorre porque as perdas de terra por erosão seriam superestimadas e subestimadas pelas funções lineares: $a+b E I A$ e $a+b E I_{30}$, respectivamente, para as chuvas de baixas e elevadas intensidades (Carvalho, 1992).

Por outro lado, este fato não ocorre na função exponencial, visto que o seu ajuste proporciona, para baixas ou elevadas intensidades, menores desvios entre os dados observados e sua curva de regressão. Por conseguinte, existiria uma estreita correlação entre chuvas tropicais de altas intensidades, enormes enxurradas e as perdas de terra por erosão. Portanto, os parâmetros erosividade, que incluem o parâmetro enxurrada, teriam uma melhor correlação com as perdas de terra na faixa tropical, do que na temperada do globo terrestre (Carvalho, 1992).

\subsubsection{Equações de regressão linear simples e linear múltiplas}

Na tabela 5 pode-se constatar que os coeficientes de determinação variaram de 0,5776 a 0,6604 para os parâmetros: EIA e $\mathrm{El}_{30}+\mathrm{Vu}$. Pode-se constatar também que os parâmetros erosividade da chuva-enxurrada, expressos por equações lineares simples e lineares múltiplas, apresentaram coeficientes de determinação $\left(r^{2}=0,5776\right.$ a 0,6604$)$ 
intermediário entre os parâmetros erosividade da chuva-enxurrada expressos por modelos não lineares $\left(r^{2}=0,8468\right.$ a 0,8729$)$ e os parâmetros erosividade da chuva $\left(r^{2}=0,3300\right.$ a 0,5615$)$.

Os resultados obtidos foram inferiores aos obtidos em Campinas-SP $\left(r^{2}=0,6503\right.$ a 0,7034) e em Mococa-SP $\left(r^{2}=0,6960\right.$ a 0,7315$)$ por Carvalho (1992) e maiores que os obtidos em Pindorama-SP $\left(r^{2}=0,4564\right.$ a 0,5350) por Carvalho (1992). Os resultados obtidos foram em geral inferiores aos obtidos nos E.U.A ( $r^{2}=0,410$ a 0,951) por Foster et al. (1982).

Para as condições edafoclimáticas de Sumé-PB, os parâmetros erosividade da chuva-enxurrada expressos por equação linear múltipla, explicaram melhor as perdas de terra, do que os parâmetros erosividade da chuva, que utilizaram o modelo linear simples.

O modelo linear múltiplo expresso pela combinação dos parâmetro $\mathrm{El}_{30}+\mathrm{V}_{\mathrm{u}}$, apresentou uma melhora no coeficiente de determinação $\left(r^{2}=0,6604\right)$, quando comparado aos modelos lineares simples tais como: EIW $_{25}\left(r^{2}=0,5513\right)$, EIW $_{30}\left(r^{2}=0,5455\right)$ e El $30 \quad\left(r^{2}=0,5391\right)$. Portanto, os resultados obtidos, indicam que para as condições edafoclimáticas do experimento, que o processo erosivo estaria mais associado a erosão em sulco.

Através dos valores da tabela 5 constatou-se também, que o modelo linear múltiplo EIA $+V_{u}\left(r^{2}=0,6534\right)$ melhorou as explicações das perdas de terra, quando comparado com o parâmetro erosividade EIA $\left(r^{2}=\right.$ 0,5776).

Em termos absolutos, o parâmetro erosividade da chuvaenxurrada; $E l_{30}+V_{u}\left(r^{2}=0,6604\right)$, apresentou um coeficiente de determinação superior ao do parâmetro $E I A+V_{u}\left(r^{2}=0,6534\right)$.

$O$ parâmetro erosividade da chuva enxurrada $\mathrm{El}_{30}+\mathrm{EIA}$ $\left(r^{2}=0,6003\right)$, ainda que tenha apresentado um maior coeficiente de determinação do que o parâmetro EIA $\left(r^{2}=0,5776\right)$, apresentou um coeficiente 
de determinação $\left(r^{2}\right)$ inferior aos obtidos para os parâmetros erosividade da chuva-enxurrada tais como: $\mathrm{El}_{30}+\mathrm{V}_{\mathrm{u}}\left(r^{2}=0,6604\right)$ e $\mathrm{EIA}+\mathrm{V}_{\mathrm{u}}\left(r^{2}=0,6534\right)$.

Os resultados relativos aos parâmetros erosividade da chuva-enxurrada expresso por modelos lineares múltiplos a saber: $\mathrm{El}_{30}+\mathrm{V}_{\mathrm{u}} \mathrm{e}$ $\mathrm{EIA}+\mathrm{V}_{\mathrm{u}}$, respectivamente, corroboram com os obtidos por Lombardi Neto (1979); Foster et al. (1982) e Carvalho (1992), mormente no que diz respeito a pressuposição de que a combinação de parâmetros erosividade da chuva e enxurrada em um único parâmetro, proporcionariam resultados mais satisfatórios em relação àqueles em que estaria incluso apenas o parâmetro erosividade da chuva.

$\mathrm{Na}$ tabela 5, pode-se constatar que os resultados obtidos para os parâmetros erosividade da chuva-enxurrada do tipo: $(1 / 2) \mathrm{El}_{30}+(1 / 2) \mathrm{Vu}_{\mathrm{u}}(\alpha .15)^{1 / 3}\left(\mathrm{r}^{2}=0,6481\right)$ e $(1 / 2) \mathrm{El} 30+(1 / 2) \mathrm{Vu}(\alpha .130)^{1 / 3}$ $\left(r^{2}=0,6399\right)$, não foram superiores aos obtidos para os parâmetros $E / 30+V_{u}$ $\left(r^{2}=0,6604\right)$ e $E I A+V u\left(r^{2}=0,6534\right)$.

Os parâmetros erosividade da chuva-enxurrada, expressos por modelos lineares múltiplos a saber: EIA + Vu. $(\alpha \cdot 15)^{1 / 3}\left(r^{2}=\right.$ $0,6510)$ e $E I A+V_{u} \cdot(\alpha \cdot 130)^{1 / 3}\left(r^{2}=0,6492\right)$ não apresentaram melhorias na estimativa das perdas de terra, em relação aos seguintes parâmetros: EIA + $V_{u}$ $\left(r^{2}=0,6534\right)$ e $E l 30+V_{u}\left(r^{2}=0,6604\right)$. Constatou-se também não haver melhoras significativas na estimativa das perdas de terra entre os parâmetros erosividade da chuva-enxurrada que utilizaram os termos ( $\alpha .15)$ e ( $\alpha .130)$.

\subsection{Distribuição da erosividade e da precipitação pluviométrica de Sumé-PB}

$O$ parâmetro erosividade da chuva $\mathrm{E}_{30}$, vem sendo utilizado no cálculo dos fatores "R", "K" e "C" na maioria dos trabalhos que envolvem a equação universal de perdas de solo no Brasil. Portanto, neste 
trabalho para efeito de comparação será utilizado o referido parâmetro no cálculo do fatores "R" e "K" da equação universal de perdas de solo.

Portanto, nas Figuras 5 e 6, pode ser observada para efeito de comparação, a distribuição dos valores anuais e médio mensais da erosividade da chuva e da precipitação pluviométrica de Sumé-PB. $O$ valor médio anual da precipitação pluviométrica foi de $695,4 \mathrm{~mm}$, sendo que o menor e o maior valor anual foram de 245,5 e $1.453,3 \mathrm{~mm}$, respectivamente. $O$ valor médio anual do fator "R" foi de $4928 \mathrm{MJ} . \mathrm{mm} / \mathrm{ha}$.h, sendo que o menor e o maior valor anual foram de 433 e $11.764 \mathrm{MJ} . \mathrm{mm} / \mathrm{ha} . \mathrm{h}$, respectivamente. Nas tabelas 10 e 11 (Anexo C) estão apresentados os valores mensais, médios mensais, anuais e médio anual da precipitação pluviométrica e da erosividade de Sumé.

A análise estatística dos valores anuais da precipitação pluviométrica de Sumé-PB, obteve para o desvio padrão (s) e o coeficiente de variação (C.V), os seguintes valores: $386 \mathrm{~mm}$ e 55,5\%

Os indicadores estatísticos, mostraram uma alta dispersão dos valores anuais da precipitação pluviométrica de Sumé-PB. Os valores estatísticos, portanto, refletem a irregularidade interanual da precipitação pluviométrica, que é uma das característica da região semi-árida.

Foi constatado também uma alta dispersão dos valores anuais da erosividade da chuva ( $\mathrm{s}=3614 \mathrm{MJ} . \mathrm{mm} / \mathrm{ha} . \mathrm{h}$ e $\mathrm{C} . \mathrm{V}=73 \%$ ), que provavelmente deva estar associada a distribuição da precipitação pluviométrica.

Os valores médios mensais da erosividade da chuva variaram de 0,0 a $1691 \mathrm{MJ} . \mathrm{mm} / \mathrm{ha} . \mathrm{h}$, sendo que nos meses de fevereiro, março e abril ocorreram os maiores valores a saber: 1170, 1691 e 1041 MJ.mm/ha.h. 


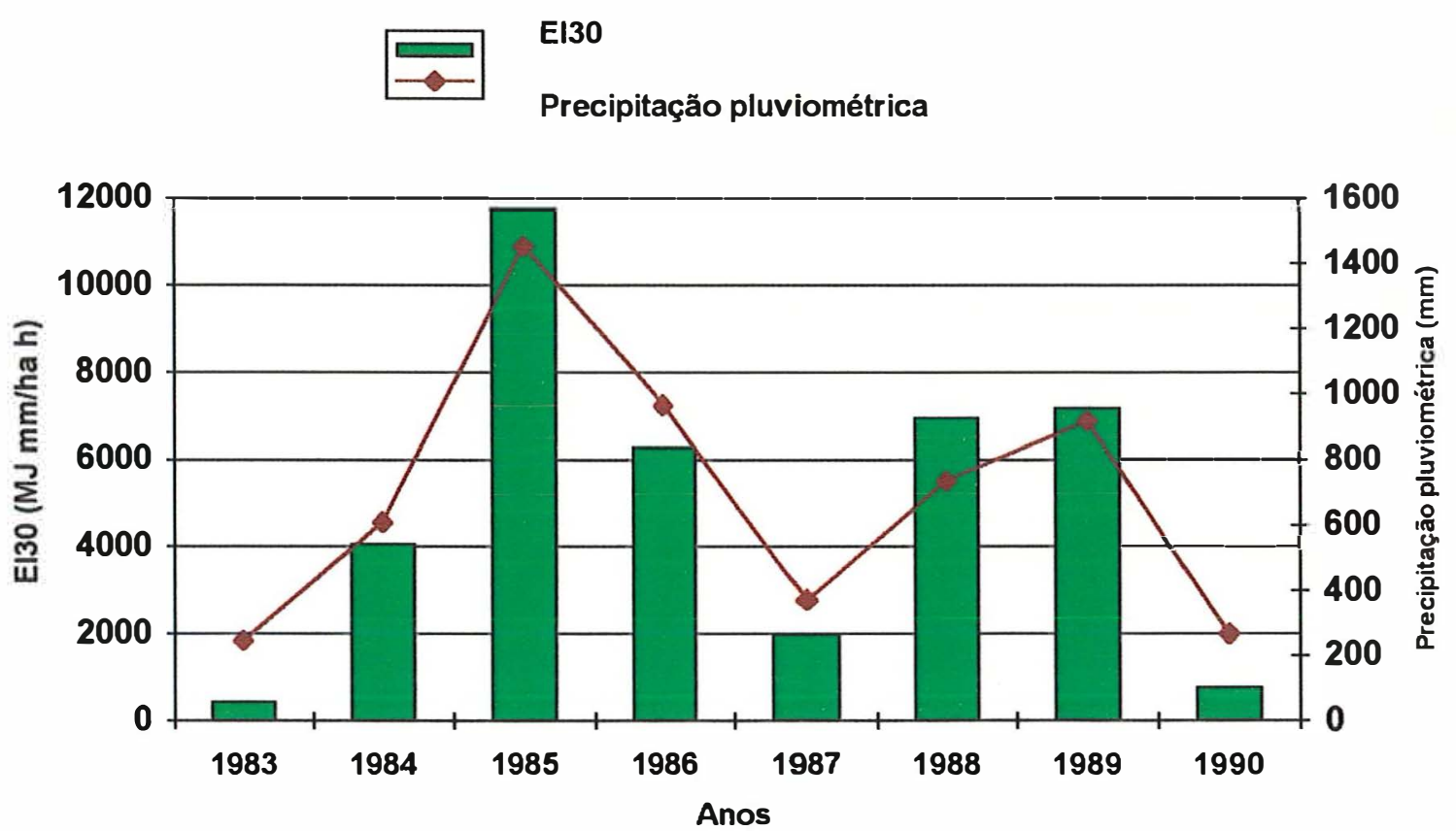

Figura 5. Valores anuais do $\mathrm{El}_{30}(\mathrm{MJ} \mathrm{mm} / \mathrm{ha} \mathrm{h}$ ) e da precipitação pluviométrica $(\mathrm{mm})$ de Sumé-PB, correspondente ao período de 1983 a 1990.

Pode-se observar através das Figuras 5 e 6, que a curva dos valores da precipitação pluviométrica e da erosividade da chuva são semelhantes, ou seja os maiores e menores valores da erosividade da chuva coincidem com a ocorrência dos maiores e menores valores da precipitação pluviométrica.

O valor médio anual do fator "R", indica a capacidade erosiva da chuva para uma determinada região, entretanto essa informação por si só não é suficiente para avaliar a capacidade potencial das chuvas de provocar erosão no decorrer do ano, sendo por conseguinte, de grande importância prática o conhecimento da distribuição dos valores médio anuais do fator R, mormente na determinação do fator uso e manejo do solo da equação universal de perdas de solo. 


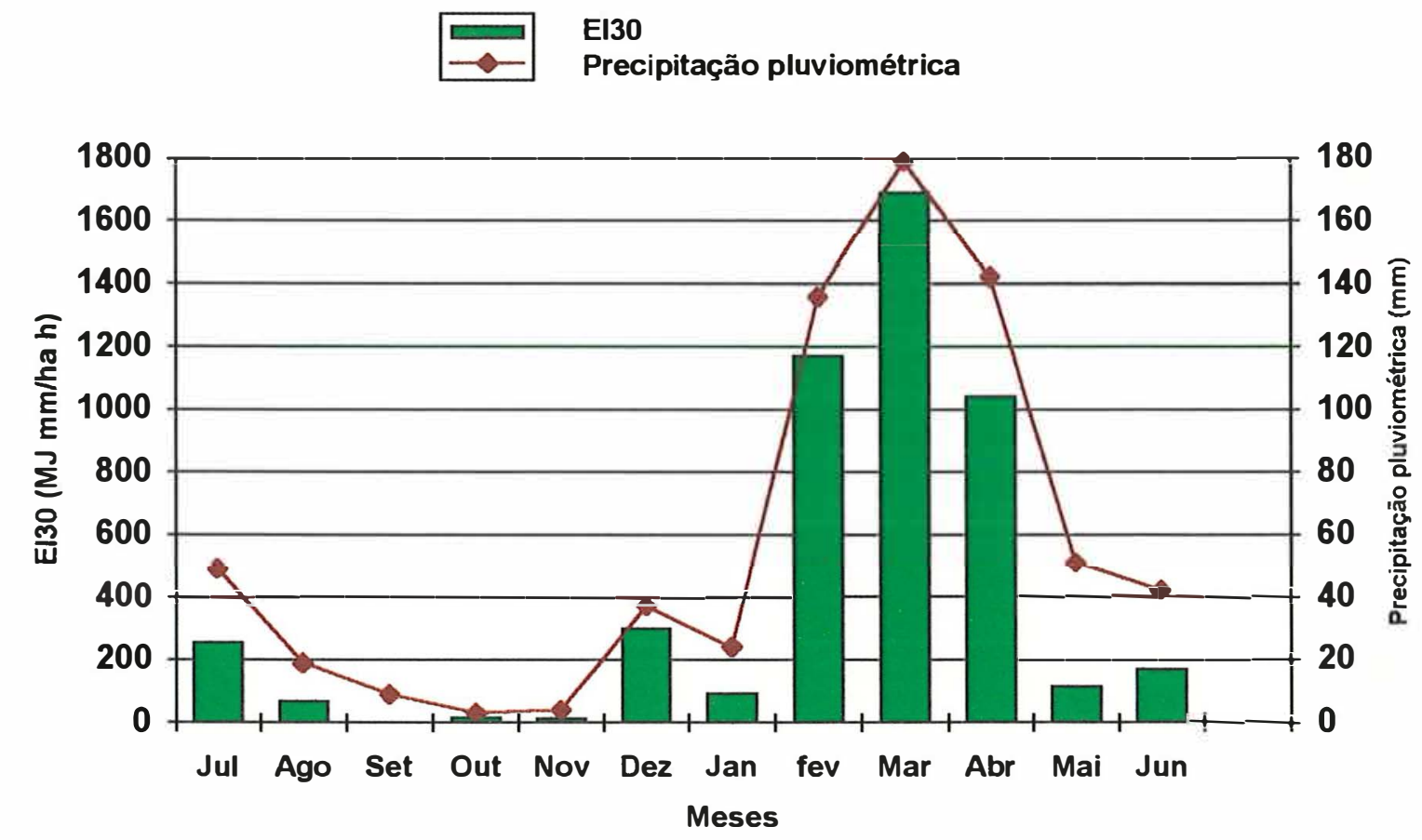

Figura 6. Valores médios mensais do $\mathrm{El}_{30}(\mathrm{MJ} \mathrm{mm} / \mathrm{ha} \mathrm{h})$ e da precipitação pluviométrica $(\mathrm{mm})$ de Sumé-PB, correspondente ao período de 1983 a 1990.

Na Figura 7 está registrada a distribuição percentual acumulada do $\mathrm{El}_{30}$ médio mensal de Sumé-PB, onde pode-se observar que o período em que a curva apresenta a maior inclinação corresponde aos meses de fevereiro, março e abril, período em que ocorrem os maiores valores do $\mathrm{El}_{30}$. Assim, observando-se a distribuição percentual acumulada do $\mathrm{El}_{30}$ médio mensal, pode-se constatar que $79,2 \%$ da erosividade da chuva ocorrem nos meses de fevereiro, março e abril. 


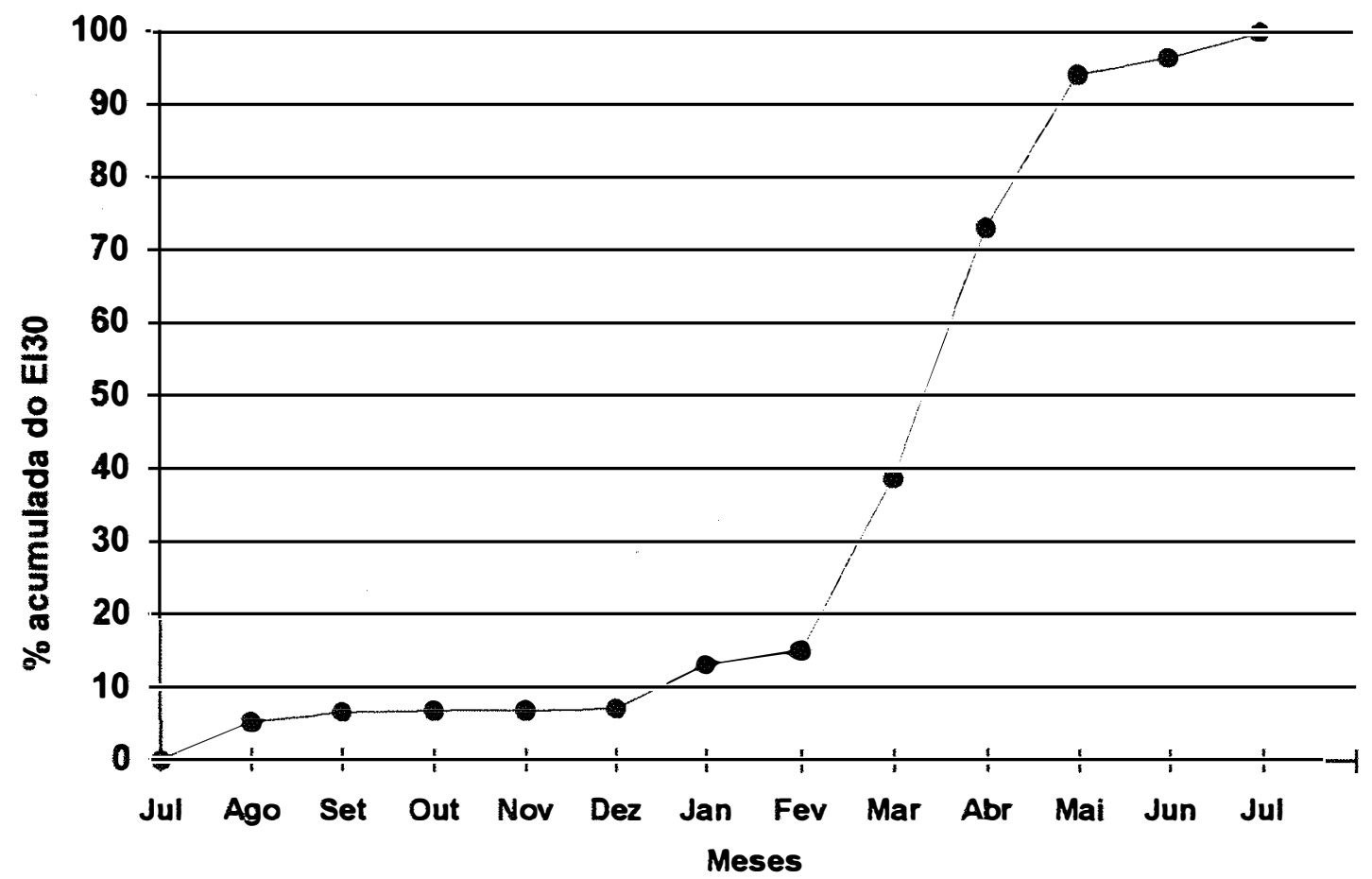

Figura 7. Valores percentuais acumulados do $\mathrm{El}_{30}$ médio mensal (MJ.mm/ha.h) de Sumé-PB.

A concentração de $79,2 \%$ da erosividade da chuva em apenas três meses (fevereiro, março e abril), é um indicador de que neste período, deva ocorrer os maiores riscos de perdas de terra e água, portanto deverão ser tomadas medidas preventivas no sentido de se evitar que ocorram perdas de terra e água de grande magnitude. Assim sendo, devem ser evitadas práticas agrícolas que intensifiquem a desagregação do solo e que remova da superfície do solo a cobertura vegetal.

\subsection{Fator erodibilidade do solo (Fator $K$ ).}

Segundo Wischmeier \& Smith (1978), existe uma relação funcional entre as perdas de terra e o fator $R$, que pode ser expressa 
pelo modelo linear simples: $A=a+b . E 130$, onde: $A$ é a estimativa da perda de terra (variável dependente) e o El30 é o parâmetro erosividade da chuva (variável independente). Considerando-se que o fator "K", é representado pelo coeficiente de regressão "b"; quando os dados obtidos são oriundos de parcela padrão, é que o fator erodibilidade estimado para o solo Bruno Não Cálcico vértico foi de 0,010 t.ha.h/ha.MJ.mm, conforme a seguinte equação linear:

\section{$A=0,796648+0,010012 \cdot E_{30}$,}

onde: A é a estimativa da perda de terra $(\mathrm{Mg} / \mathrm{ha})$ e o $\mathrm{El}_{30}$ é o parâmetro erosividade da chuva (MJ.mm/ha.h)

Os valores obtidos para os coeficientes de regressão (a) e (b) respectivamente, relativos ao parâmetro $\mathrm{EWI}_{30}$, foram semelhantes aos obtidos para o parâmetro $\mathrm{El}_{30}$. Portanto, o valor obtido para o fator $\mathrm{K}$, através do coeficiente de regressão (b), foi de 0,010 t.ha.h/ha.MJ.mm, conforme a equação abaixo descrita.

$$
A=0,755339+0,010112 . E W / 30
$$

onde: A é a estimativa da perda de terra $(\mathrm{Mg} / \mathrm{ha})$ e 0 ElW $_{30}$ é o parâmetro erosividade da chuva (MJ.mm/ha.h)

De acordo com a classificação estabelecida por Foster et al. (1981), o valor obtido para o fator K do terra Bruno Não Cálcico, foi considerado baixo.

$O$ valor obtido para o fator $K$ no presente trabalho (0,010 t.ha.h/ha.MJ.mm), ocupou uma posição intermediária entre os dois valores obtidos para 0 solo Bruno Não Cálcico $(0,008$ e 0,044 t.ha.h/ha.MJ.mm), conforme relatados por Denardin (1991). 
Deve-se ressaltar, que 0 fator $K$ estabelecido a partir dos 23 principais solos dos E.U.A., deixa praticamente de lado os solos montmoriloníticos (Vertissolos) e os solos pedregosos como no caso do solo Bruno Nâo Cálcico (Wischmeier \& Smith, 1978). Portanto, para solos rasos, com montmorilonita dominante, com fase pedregosa, a EUPS tem que ser aplicada com cautela. 


\subsection{Análise das perdas de terra e água das parcelas experimentais}

\subsubsection{Efeito do desmatamento e do manejo do solo sobre as perdas de terra}

$\mathrm{Na}$ tabela 6 estão registrados os valores anuais e médios anuais das perdas de terra das nove parcelas experimentais, ocorridas no período de 1983 a 1990. Os valores médios mensais de perda de terra das nove parcelas experimentais estão apresentados na tabela 12 (Anexo C).

Os valores médios anuais obtidos para as parcelas desmatadas $(3,8 \%)$ e com cobertura morta $(3,9 \%)$; que possuem declividades semelhantes, foram de 35,7 e 0,31 $\mathrm{Mg} / \mathrm{ha}$. Através dos valores obtidos, constatou-se que a parcela dematada perdeu 115 vezes mais terra do que a parcela com cobertura morta. Os valores acima mencionados corroboram com os relatados por Ramos \& Marinho, (1980); Freitas et al., (1981) e Silva et al., (1989).

A alta relação de perdas de terra obtida entre as parcelas desmatadas e com cobertura morta, está associada a remoção da cobertura vegetal da superfície do solo. O desmatamento, ao remover a cobertura vegetal, possibilitou à ação do impacto das gotas de chuva sobre o solo, e por conseguinte, a dissipação de sua energia cinética sobre a superfície do mesmo, possibilitando o desprendimento das partículas do solo, salpicamento e transporte pela enxurrada, contribuindo para aumentar as perdas de terra.

A remoção da cobertura vegetal possibilitou uma ação mais efetiva do impacto das gotas de chuva sobre a superfície do solo, favorecendo além da desagregação das partículas do solo, o selamento superficial. Este fato contribuiu para dificultar a infiltração de água, aumentando o volume de enxurrada na superfície. Dados de pesquisas, indicam que em solos onde ocorreu o selamento superficial, houve um aumento 


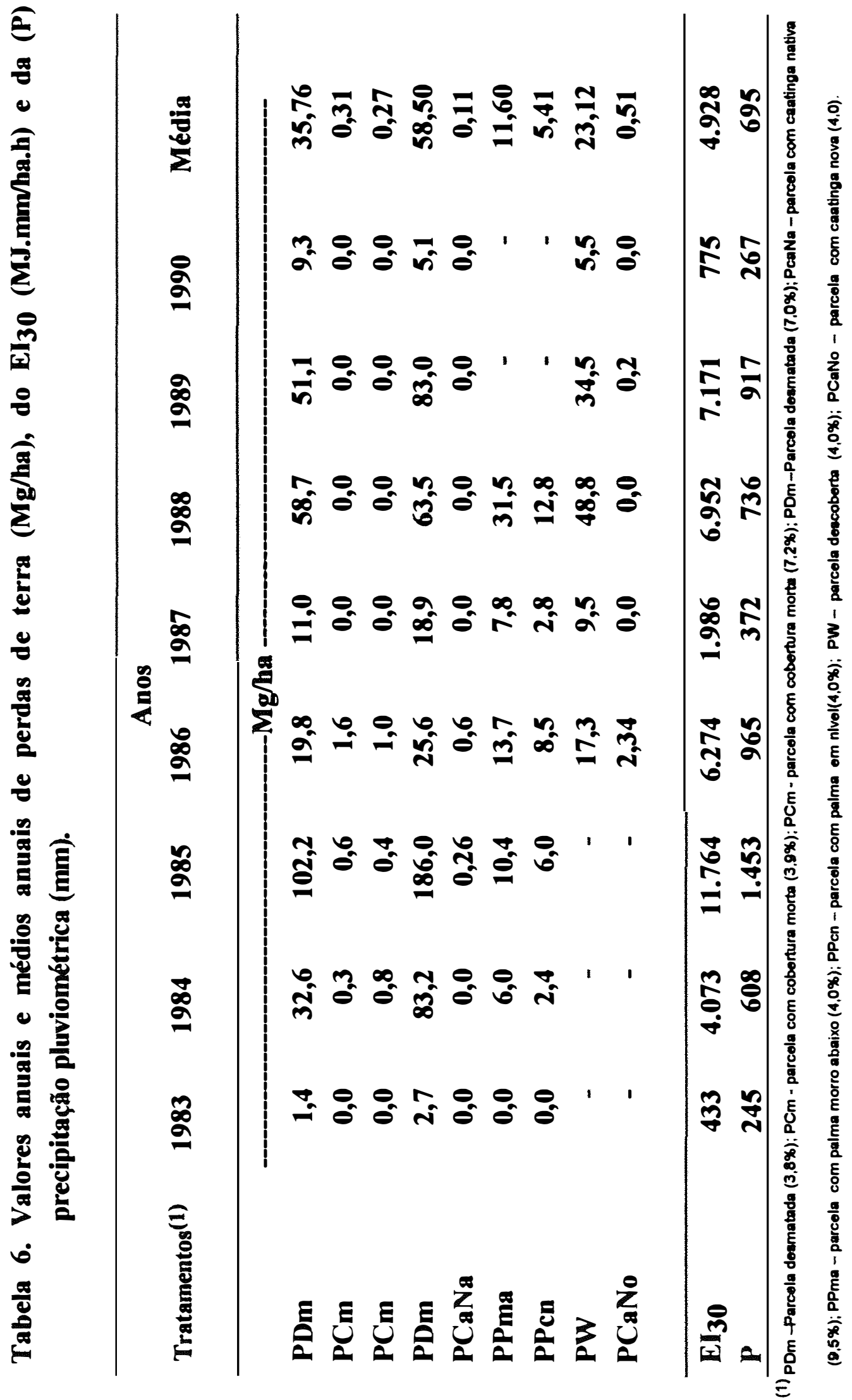


significativo das perdas de terra (Ramos \& Marinho, 1980; Singer et al., 1981; Bertol et al., 1989; Sidiras et al., 1984; Carvalho et al., 1990; e Steiner, 1994).

O fato da parcela com cobertura morta ter reduzido as perdas de terra em 99,0\%, quando comparada com a parcela desmatada, é explicado quando se considera que a cobertura morta ao aumentar a rugosidade superficial, contribuiu para a reduzir a velocidade da enxurrada, a concentração de sedimentos e o poder de desagregação e transporte da enxurrada. Assim, a cobertura morta ao forçar a sedimentação das partículas transportadas, reduziu a capacidade abrasiva das partículas da enxurrada. Os resultados obtidos corroboram com os obtidos por Carvalho et al. (1990); Livien et al. (1990); Derpsch et al. (1991) e Albert \& Neibling, (1994).

Várias pesquisas têm evidenciado que a cobertura morta tem contribuído para aumentar o volume de água retida na superfície, bem como o seu efeito em prevenir o selamento superficial do solo provocado pelo impacto direto das gotas de chuva, melhorando a capacidade de infiltração de água. O aumento do tempo do início da enxurrada, tem sido também relatado como um dos efeitos da cobertura morta, que tem contribuído para aumentar o tempo de infiltração do escoamento superficial, reduzindo por conseguinte as perdas de terra (Ben-Hur et al., 1987; Bertol et al., 1989; Carvalho et al., 1990; Mohamoud \& Ewing, 1990; Derpsch et al., 1991; Reichert \& Cabeda, 1992; Albert \& Neibling 1994).

$\mathrm{Na}$ tabela 6 pode-se observar que as perdas média anuais das parcelas com cobertura morta $(7,2 \%)$ e desmatada $(7,0 \%)$, foram de 0,27 e $58,5 \mathrm{Mg} / \mathrm{ha}$ respectivamente. Através da relação de perdas de terra entre as parcelas desmatadas e a parcela com cobertura morta, constatou-se que a parcela desmatada perdeu 158 vezes mais terra do que a parcela com cobertura morta.

A partir dos resultados obtidos para as parcelas desmatadas, constatou-se que o desmatamento provocou um aumento 
significativo das perdas de terra. Por outro lado, foi constatado que a utilização da cobertura morta possibilitou uma redução drástica das perdas de terra. As parcelas com cobertura morta reduziram as perdas de terra em torno de $99,0 \%$, quando comparadas com as perdas de terra das parcelas desmatadas.

Os resultados obtidos para os tratamentos com cobertura morta, evidenciou a necessidade da manutenção de restos culturais sobre a superfície do solo, objetivando reduzir ao máximo as perdas de terra. Esta necessidade tem sido ressaltada por inúmeros trabalhos realizados no semiárido do Nordeste do Brasil (Ramos \& Marinho 1980; Freitas et al., 1981; Margolis et al., 1985; Silva et al., 1989; Margolis et al., 1991 e Melo Filho \& Silva 1993).

A utilização da rotação de cultura associada a prática de pousio do solo por um período mínimo de dois anos; onde a vegetação nativa surgida no período de pousio foi ceifada e deixada sobre a superfície do solo para formar uma cobertura morta antes do plantio seguinte, resultou num excelente controle das perdas de terra e água conforme relatado por Freitas et al. (1981). Os resultados obtidos no presente trabalho mostrou que a cobertura morta oriunda da vegetação nativa, pode ser utilizada em sistemas agrícolas que utilizem as rotações bienais ou trienais e o pousio do solo como prática de manejo, como relatado por Freitas et al. (1981).

O valor médio anual das perdas de terra, obtido para a parcela descoberta em alqueive contínuo $(4,0 \%)$ foi de $23,1 \mathrm{Mg} / \mathrm{ha}$ (Tabela 6). Os dados obtidos da parcela descoberta correspondem ao periodo de 1986 a 1990. Uma análise comparativa dos valores médios anuais do período de 1986 a 1990 da parcela descoberta em alqueive contínuo (4\%) com a parcela com cobertura morta $(3,9 \%)$, constatou-se que a parcela descoberta $(23,1 \mathrm{Mg} / \mathrm{ha})$ perdeu 72,2 vezes mais terra do que a parcela com cobertura morta $(0,32$ $\mathrm{Mg} / \mathrm{ha}$ ), ou seja, a parcela com cobertura morta apresentou um controle das 
perdas de terra da ordem de $98,6 \%$, quando comparada com a parcela descoberta em alqueive contínuo (Tabela 6).

Os resultados obtidos no presente trabalho, confirmam a preocupação de diversos autores com o processo de desmatamento que vem ocorrendo no semi-árido Nordeste do Brasil e o seu impacto sobre o meio ambiente. Dentro deste contexto deve-se ressaltar a fragilidade ecológica da região semi-árida do Nordeste do Brasil e a sua susceptibilidade a desertificação, devido à ocorrência de secas, às características de clima e solo e a ação do homem, favorecida pela pressão demográfica, resultando no alarmante processo de degradação que a região está sofrendo (Vasconcelos Sobrinho, 1983; Mendes, 1986; Reis, 1988 e Araújo Filho \& Carvalho 1996).

Os resultados obtidos indicam que 0 indiscriminado desmatamento da caatinga para a prática de uma agricultura itinerante e para a coleta de madeira para construções, cercas, lenhas e carvão, pode aumentar o risco de perdas de terra de forma considerável se não forem tomadas medidas adequadas de conservação e manejo do solo.

O risco de perdas de terra para as condições edafoclimáticas de Sumé-SP, poderá ser bem maior, mormente quando se considera o fato de que o manejo das parcelas desmatadas, incluía apenas a remoção da vegetação com enxada, quando a mesma atingia $5 \mathrm{~cm}$ de altura. Num processo agrícola que implique em uma mobilização mais intensiva do solo, o risco de perdas de terra poderá ser maior do que os obtidos nas parcelas desmatadas.

Os resultados obtidos servem também de advertência para o planejamento de obras hidráulicas, que visem a construção de açudes, visto que, o desmatamento da área de captação pode provocar assoreamento, comprometendo a vida útil da obra.

Os valores médios anuais de perda de terra das parcelas cultivadas com palma morro abaixo $(4,0 \%)$ e palma cultivada em nível $(4,0 \%)$, 
correspondentes ao período 1983 a 1988, estão apresentados na tabela 6 . Comparando-se entre si, os resultados obtidos das parcelas com palma morro abaixo $(4,0 \%)$ e palma em nivel $(4,0 \%)$, pode-se observar que a parcela com palma morro abaixo perdeu 2,1 vezes mais terra do que a parcela com palma em nível. Os resultados obtidos evidenciaram a influência do cultivo em nível sobre as perdas de terra. Assim, o cultivo em nível, contribuiu para reduzir em $53,4 \%$, as perdas de terra, quando comparado com o cultivo morro abaixo, portanto corroborando com os resultados obtidos por Margolis \& Campos Filho (1980); Margolis et al. (1985); Bertoni \& Lombardi Neto (1985); Margolis et al. (1991) e Silva et al. (1989.

Quando também se compara os valores obtidos das parcelas com palma morro abaixo (11,6 Mg/ha) e palma em nivel (5,4 Mg/ha), com o valor obtido da parcela desmatada $(37,6 \mathrm{Mg} / \mathrm{ha})$ no período de $1983 \mathrm{a}$ 1988, constatou-se que as parcelas com palma morro abaixo e em nivel proporcionaram uma redução das perdas de terra da ordem de 69,6 e $85,6 \%$.

$\mathrm{Na}$ tabela 6, estão apresentados os valores médios anuais das parcelas com caatinga nativa e caatinga nova. As respectivas perdas média anuais de terra foram de 0,11 e 0,51 Mg/ha. Através da análise comparativa entre os valores médios anuais de perda de terra das respectivas parcelas no período de 1986 a 1990, constatou-se que a parcela com caatinga nova perdeu 3,0 vezes mais terra do que a parcela com caatinga nativa. Apesar da parcela com caatinga nova ter uma declividade menor em relação a parcela com caatinga nativa, a maior perda de terra ocorreu, devido ao fato de que a parcela com caatinga nova foi cortada no início do experimento para posterior rebrotamento, ficando durante os primeiros anos mais exposta à ação do impacto das gotas de chuva, e por conseguinte mais suscetível à ação dos agentes erosivos (Tabela 6), concordando com os resultados obtidos por Ramos \& Marinho (1980). 
Quando comparada com a parcela descoberta e em alqueive contínuo a parcela com caatinga nova reduziu as perdas de terra em 99,5\%, corroborando com os resultados obtidos por Ramos \& Marinho (1980). As perdas de terra da parcela com caatinga nativa $(9,5 \%)$, quando comparada com as perdas de terra da parcela desmatada $(3,8 \%)$, foram reduzidas em $99,7 \%$.

$\mathrm{Na}$ tabela 6 pode-se observar, que os valores médios anuais obtidos para as parcelas desmatadas foram de 35,7 e $58,5 \mathrm{Mg} / \mathrm{ha}$. Os resultados obtidos mostram que a parcela desmatada com $7,0 \%$ de declividade perdeu 1,63 vezes mais terra do que a parcela desmatada com $3,8 \%$ de declividade. Considerando que as parcelas desmatadas possuem a mesmas dimensões, o mesmo tipo de solo, as mesmas condições de manejo e foram submetidas as mesmas condições climáticas; os valores obtidos evidenciam o efeito da declividade, que nas respectivas parcelas são de 3,8 e 7,0\%.

Os resultados obtidos indicam, que o aumento do grau de declive, pode aumentar de forma significativa o risco de perdas de terra no solo Bruno Não Cálcico, mormente na região Semi-árida do Brasil, onde o cultivo morro abaixo é uma prática cultural enrraigada. Portanto, o desmatamento predatório da caatinga para atender a demanda energética da região, mormente em áreas com grau de declive acentuado, pode contribuir para acelerar a degradação do solo Brunos Não Cálcico.

\subsubsection{Efeito do desmatamento e do manejo do solo sobre as perdas de água}

$\mathrm{Na}$ tabela 7 podem ser observados os valores anuais $\mathrm{e}$ médios anuais das perdas de água, obtidos para as nove parcelas experimentais, ocorridos no período de 1983 a 1990. Na tabela 13 do anexo C, estão apresentados os valores médios mensais de perda de água das parcelas experimentais. 
Comparando-se os valores obtidos das parcelas desmatada $(3,8 \%)$ e com cobertura morta $(3,9 \%)$, que possuem declividades semelhantes, constatou-se que a parcela desmatada $(224,2 \mathrm{~mm})$ perdeu 3,4 vezes mais água do que a parcela com cobertura morta $(65,0 \mathrm{~mm})$. Assim, as perdas de água das parcelas desmatadas e com cobertura morta, em relação a precipitação média anual $(695,4 \mathrm{~mm})$, foram de 32,3 e $9,4 \%$. Através do resultados obtidos, constatou-se que as parcelas desmatadas e com cobertura morta possibilitaram uma infiltração de 471,2 e 630 mm respectivamente. Assim, foi constatado a partir dos valores acima citados que a parcela com cobertura morta, quando comparada com a parcela desmatada, contribuiu para aumentar a infiltração da água em torno de $159 \mathrm{~mm}$.

O solo Bruno Não Cálcico Vértico, tem permeabilidade moderada. Leprun et al. (1983), relatam que a permeabilidade do referido solo foi em torno de $26 \mathrm{~mm} / \mathrm{h}$ pelo método de Müntz. Portanto, a permeabilidade do solo Bruno Não Cálcico Vértico, pode ser reduzida, em função do desmatamento e da natureza da mobilização do solo feita posteriormente. Ramos \& Marinho (1980) constataram que para as condiçōes edafoclimáticas do semi-árido do Ceará; a infiltração do solo foi reduzida aproximadamente pela metade, quando foi efetuado o desmatamento da caatinga.

Por outro lado, a utilização da cobertura morta contribuiu para proteger a superfície do solo, através da interceptação do impacto das gotas de chuva sobre o solo, atenuando o processo de selamento, por conseguinte, favorecendo a retenção superficial de água e o processo de infiltração. Na medida em que a infiltração foi favorecida, as perdas de água por escoamento superficial foram reduzidas.

Considerando que a irregularidade e a baixa precipitação pluviométrica é uma das principais caracteristicas da região, a cobertura morta apresenta uma função importante no controle das perdas da água, mormente no processo de evaporação. 


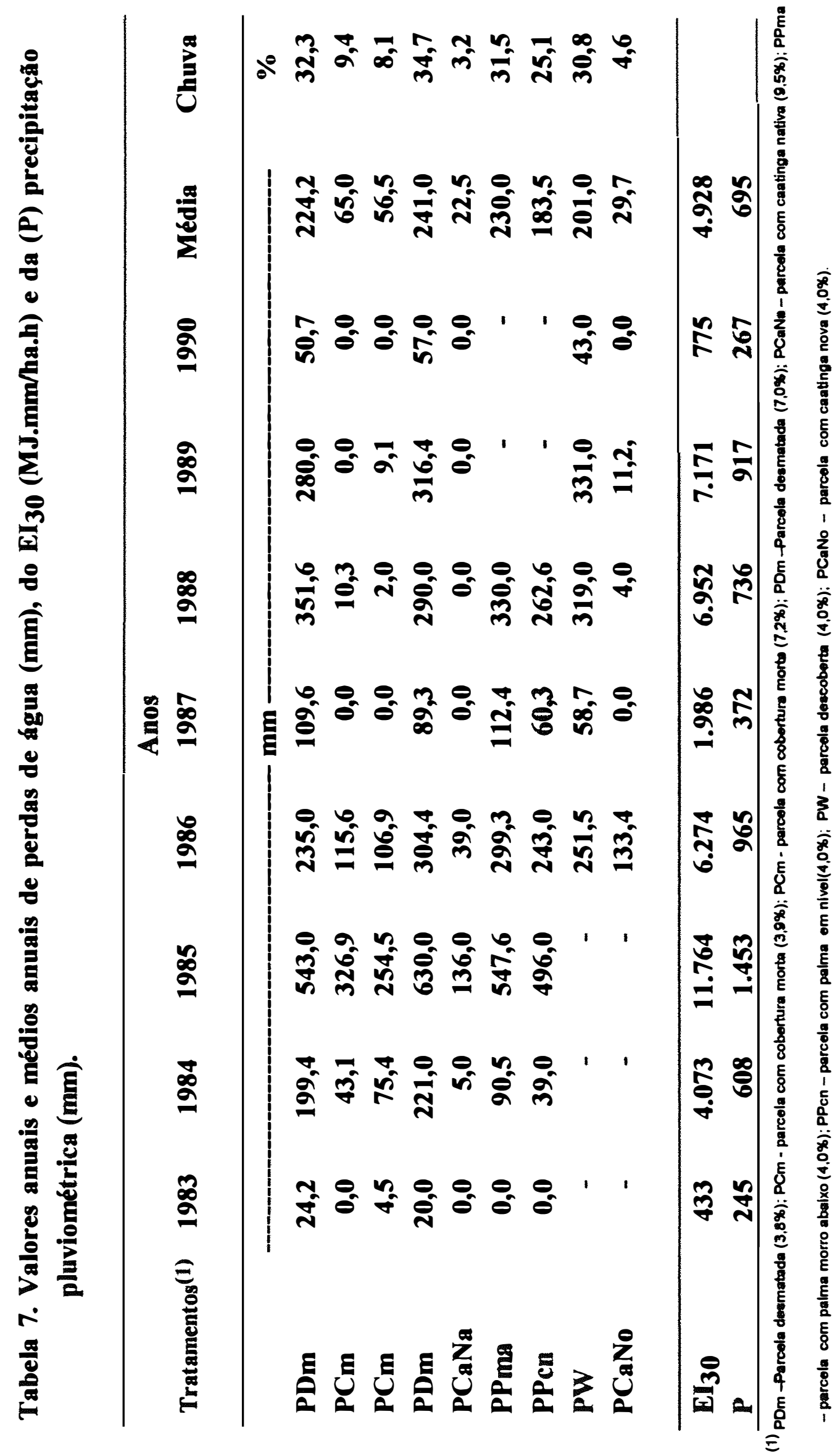


$\mathrm{Na}$ tabela 7 pode-se observar que as perdas média de água das parcelas com cobertura morta $(7,2 \%)$ e desmatada $(7,0 \%)$ foram de 56,5 e $241,0 \mathrm{~mm}$. As perdas de água das respectivas parcelas em relação a precipitação pluviométrica média anual foram de 8,1 e $34,6 \%$. Através dos dados obtidos constatou-se que a parcela com cobertura morta, reduziu as perdas de água em $76 \%$, quando comparada com a desmatada.

A partir dos resultados obtidos, constatou-se que a parcela com cobertura morta $(7,2 \%)$ contribui para que dos $695,4 \mathrm{~mm}$ da precipitação pluviométrica média anual, $639,4 \mathrm{~mm}$ se infiltrasse no solo, ou seja, $91,9 \%$ da água da chuva. Assim, a parcela com cobertura morta contribuiu para um aumento de $41 \%$ na infiltração da água, quando comparada com a parcela desmatada $(7,0 \%)$.

$\mathrm{Na}$ tabela 7 estão apresentados os valores médios anuais de perda de água das parcelas com palma morro abaixo e palma em nível, correspondente ao período de 1983 a 1988. As perdas médias anuais de água foram de 230,0 e $183,5 \mathrm{~mm}$. As perdas de água das parcelas com palma cultivada morro abaixo e palma cultivada em nivel em relação a precipitação pluviométrica média anual $(729,8 \mathrm{~mm})$, correspondente ao período de 1983 a 1986, foram de 31,5 e $25,1 \%$ respectivamente. Comparando-se entre si os valores médios anuais de perda de água das parcelas com palma morro abaixo e palma em nível, constatou-se que o cultivo em nível contribuiu para reduzir em $20,1 \%$ as perdas de água em relação ao cultivo morro abaixo.

Quando comparada com as perdas de água da parcela em alqueive contínuo com as perdas de água da parcela com caatinga nova, constatou que a parcela com caatinga reduziu as perdas de água em $85,2 \%$. Constatou-se também que parcela com caatinga nativa quando comparada com as parcelas desmatadas, reduziram as perda de água em torno de $90,0 \%$.

Considerando, que extensas áreas do semi-árido do Nordeste do Brasil já foram desmatada, estando o restante sob constante 
ameaça de desmatamento, os resultados obtidos são de suma importância, para o planejamento de áreas de alto risco erosivos como aquelas inseridas sobre o embasamento cristalino com solos rasos, arenosos, com horizonte B textural e com declividades acentuadas.

\subsection{Análise das perdas de terra e água das microbacia}

\subsubsection{Análise das perdas de terra}

Os valores anuais e médios anuais das perdas de terra das microbacias experimentais, correspondente ao período de 1983 a 1990 estão apresentados na tabela 8 . Os valores médios mensais estão apresentados na 13 do anexo $\mathrm{C}$.

$\mathrm{Na}$ tabela 8 pode-se observar que os valores médios anuais de perda de terra das microbacias com caatinga nativa foram de 0,12 e $0,14 \mathrm{Mg} / \mathrm{ha}$ respectivamente. Apesar da caatinga não ter a mesma pujança, que tem por exemplo uma floresta de mata atlântica, os resultados obtidos indicam um eficiente controle da erosão por parte da caatinga.

Este fato está provavelmente associado a extraordinária capacidade de rebrota da caatinga por ocasião das primeiras chuvas, formando um dossel semelhante a uma floresta baixa, capaz de atenuar os efeitos do impacto das gotas de chuva sobre o solo. Por outro lado, durante a estação seca a caatinga hiperxerófila caracteriza-se por uma vegetação arbustiva densa.

Este fato torna-se mais evidente, quando se compara os valores médios anuais de perda de terra das microbacias com caatinga nativa $(0,12$ e $0,14 \mathrm{Mg} / \mathrm{ha})$, com os valores obtidos das microbacias desmatadas (31,0 e 26,0 Mg/ha), onde constatou-se uma redução de perdas de terra entre 99,4 e $99,6 \%$. 


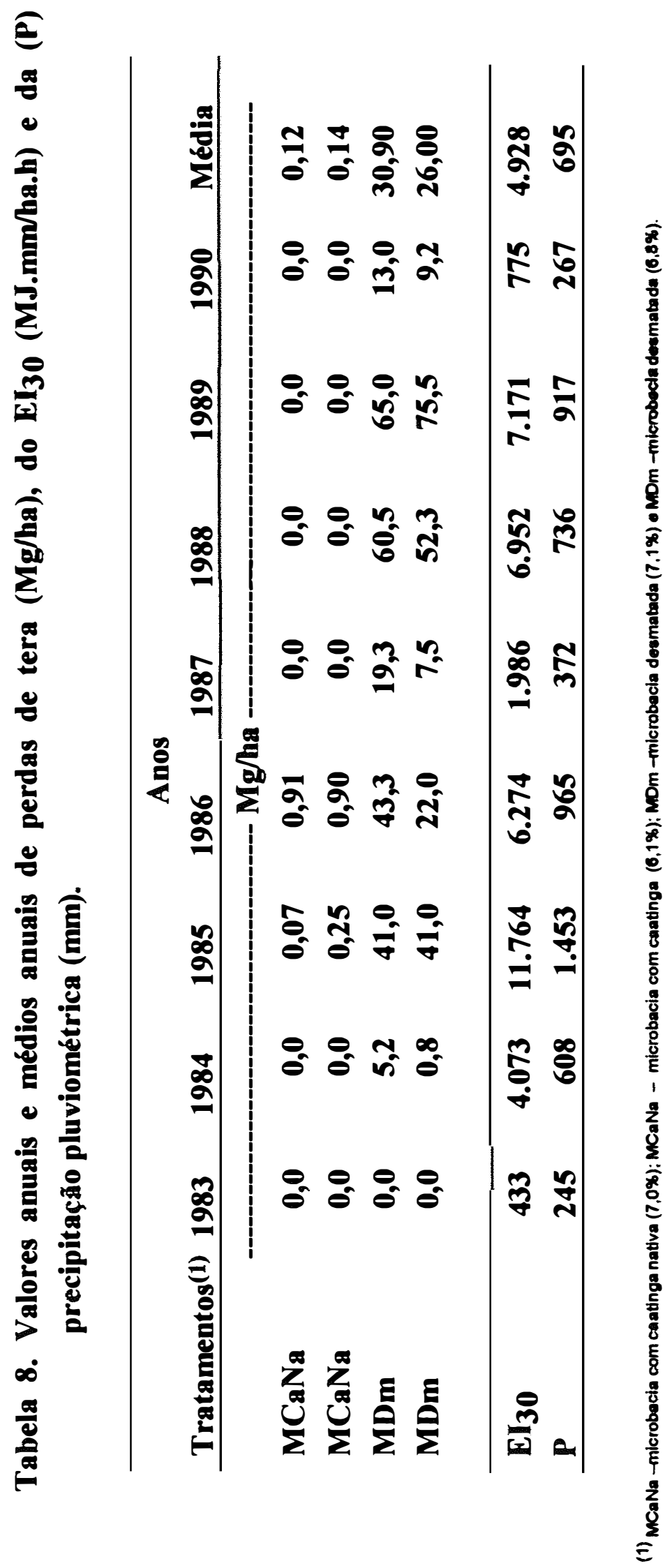


Os dados obtidos em Sumé-PB, são similares aqueles obtidos por Ramos \& Marinho (1980), que constataram que a parcela com caatinga nativa reduziu as perdas de terra em $99 \%$, quando comparada com a parcela descoberta. As microbacias com caatinga nativa, apresentaram perdas de terra praticamente iguais 0,12 e $0,14 \mathrm{Mg} / \mathrm{ha}$, refletindo o comportamento homogêneo da cobertura vegetal na proteção oferecida ao solo. Os valores obtidos para as microbacias com caatinga nativa, foram ligeiramente superiores ao obtido para a parcela com caatinga nativa $(0,11 \mathrm{Mg} / \mathrm{ha})$.

Os valores médios anuais de perda de terra para as microbacias desmatadas foram de 31,0 e 26,0 Mg/ha respectivamente (Tabela 8). Os valores obtidos para as perdas de terra nas microbacias desmatadas, quando comparados com os das microbacias com caatinga nativa, indicam um aumento significativo do desmatamento da caatinga sobre as perdas de terra.

Pode-se constatar através da tabela 8 , que as microbacias desmatadas perderam 257,5 e 185,7 vezes mais terra do que as microbacias com caatinga nativa. Estes dados indicam a importância da caatinga como agente controlador dos processos erosivos, mormente em condições de declives acentuados e de solos rasos com horizonte B textural, tal como no solo estudado.

O desmatamento indiscriminado do solo Bruno Não Cálcico pode gradativamente comprometer a flora, a fauna, a água, o solo, as nascentes, os açudes e os rios.

\subsubsection{Análise das perdas de água}

A tabela 9, apresenta os valores anuais e médios anuais das perdas de água das microbacias experimentais, correspondentes ao período de 1983 a 1990. Na tabela 13 do anexo C, estão registrados os valores médios mensais das perdas de água das quatro microbacias experimentais. 


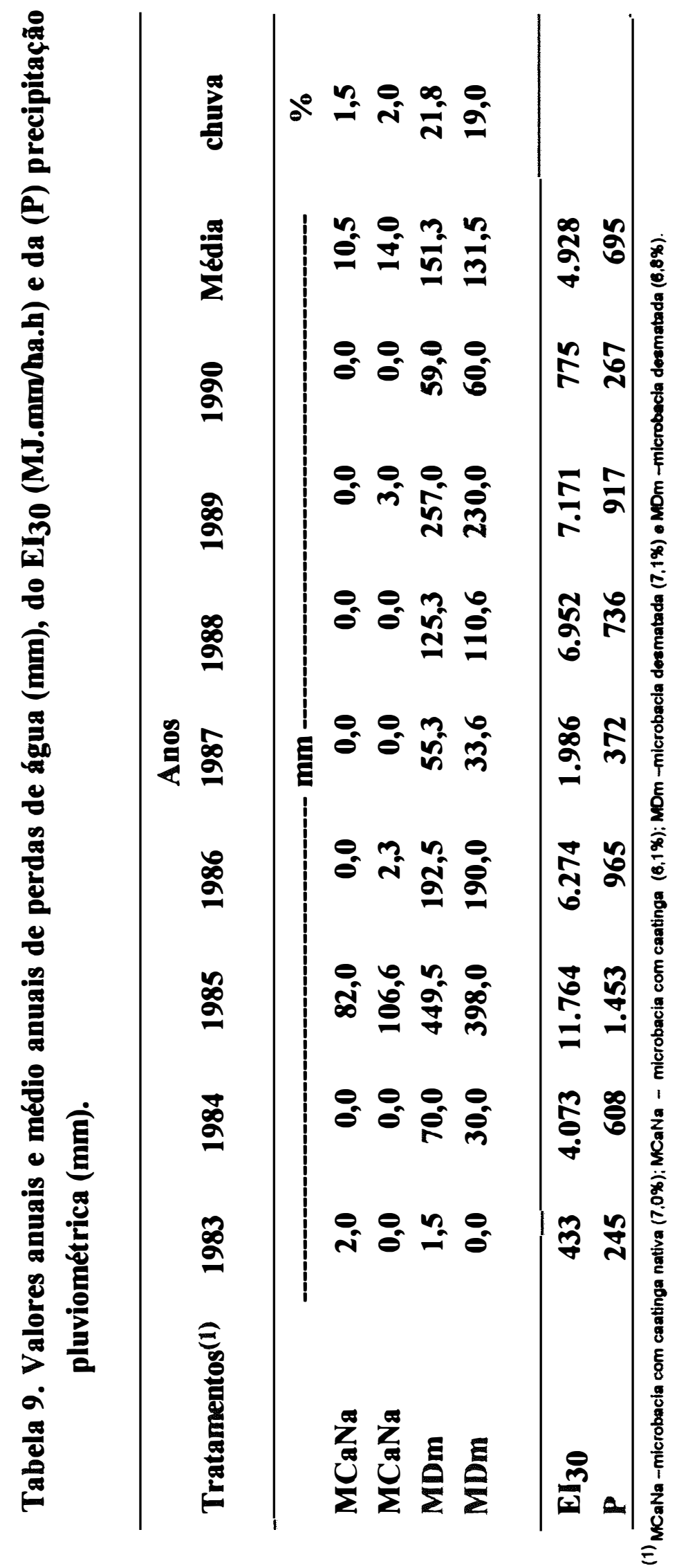


Os valores médios anuais para as microbacias com caatinga nativa foram de 10,5 e 14,0 mm. Quando comparadas com as microbacias desmatadas as microbacias com caatinga nativa, contribuiram para reduzir as perdas de água entre 89,3 e 93,0\%.

A eficiência do controle das perdas de água das microbacias com caatinga nativa foi semelhante a das parcelas com caatinga (22,5 e $29,7 \mathrm{~mm}$ ), comprovando o eficiente controle da erosão por parte da caatinga.

Apesar de no semi-árido do Nordeste do Brasil predominar os sistemas de cultivo manual e de tração animal, o desmatamento indiscriminado utilizado para atender a demanda energética e para o cultivo itinerante, se associado à práticas inadequadas de manejo do solo tais como: preparo morro abaixo, queimadas e a utilização intensa da mecanização com implementos inadequados, poderá levar o semi-árido nordestino, a um agravante processo de degradação, com risco potencial da expansão das áreas degradadas já existentes na região.

Unidades de solos localizados sobre o embasamento cristalino caracterizados por: baixos teores de matéria orgânica, baixa profundidade efetiva e horizonte B com gradiente textural; não podem ser deixados sem proteção, sem o risco de vê-los passar a um estágio severo de degradação.

\subsection{Considerações finais}

Considerando, os trabalhos até então realizados no semiárido do Nordeste do Brasil, concernente a equação universal de perdas de solo e com base no presente trabalho, é que estão sendo propostas algumas 
sugestões, objetivando tornar a equação universal de perda de solo num instrumento de planejamento das atividades agrícolas desta região do Brasil.

a) A atual rede pluviográfica e pluviométrica representam dados de suma importância para o estudo do potencial erosivo das chuvas do semi-árido, portanto uma política de manutenção da atual rede e a ampliação da rede em regiões desprovidas de informações meteorológicas deve ser um das prioridades da pesquisa conservacionista da região, visto que a densidade da rede pluviográfica é baixa para a dimensão da região. A utilização de mesas digitalizadoras acopladas a programas computacionais possibilitará a obtenção rápida dos dados pluviográficos existentes e com maior precisão. Estudos sobre as relações diâmetro das gotas de chuva $x$ intensidade $x$ energia cinética são escassos. Portanto, pesquisas deveriam ser desenvolvidas no sentido de se obter um modelo matemático que possibilitasse a obtenção mais precisa do fator erosividade da chuva.

b) Os valores do fator $K$ obtidos através de chuva natural são escassos e de uma forma geral não seguem as recomendações da parcela padrão de Wischmeier \& Smith (1978). Como o fator K varia com o passar do tempo, tendendo a aumentar a medida que o solo vai sendo cultivado, é necessário um número considerável de anos para que se possa obter dados mais estáveis, sendo que no semi-árido do Nordeste esse número de anos chega no máximo a 5 anos. Os resultados obtidos com simuladores de chuva são mais abundantes, sendo portanto a maior contribuição para o estudo do fator $\mathrm{K}$ no Nordeste do Brasil e particularmente em sua região semi-árida, não obstante os simuladores de chuva serem caros. A utilização de equações resultante da correlação entre parâmetros físicos e químicos do solo e os valores de K obtidos em condições de campo (Denardim, 1991), possibilitará a obtenção de um fator $\mathrm{K}$ mais ajustado as condições do Nordeste do Brasil, em um período menor de tempo e de forma mais barata. 
c) Os resultados obtidos com o fator uso e manejo do solo são escassos e restringe-se praticamente ao agreste do Estado de Pernambuco, entretanto os poucos resultados obtidos são promissores, sendo este um dos fatores da equação universal de perda de terra, que mais necessitam de investimento.

d) Existe uma péssima distribuição geográfica dos experimentos, restringindo a aplicação da equação universal de perdas de solo como instrumento de planejamento conservacionista a algumas regiōes do Nordeste. Para a utilização da equação universal de perdas de solo como instrumento de planejamento no semi-árido do Nordeste, seriam necessários o estabelecimento de parcelas experimentais nos principais grandes grupos de solos, para testar o nível de proteção de plantas adaptadas a região em diferentes tipos de manejo do solo e práticas conservacionistas.

e) Não existem dados para se estabelecer um modelo de previsão para o fator comprimento de rampa e grau de declive (Fator L.S). Portanto, pesquisa deveriam ser envidadas no sentido de obter-se tais valores, principalmente para áreas maiores como as microbacias. 


\section{CONCLUSÕES}

$\mathrm{Na}$ condição em que o presente trabalho foi realizado, com os materiais e métodos empregados e em decorrência dos resultados obtidos, analisados e interpretados, estabelecem-se as conclusões a seguir apresentadas.

1. Para as condições edafoclimáticas de Sumé-PB, as perdas de terra provocadas por chuvas erosivas podem ser estimadas com precisão por parâmetros erosividade da enxurrada e chuva-enxurrada expressos por equações não lineares tais como: $a\left(V_{u} \cdot \alpha \cdot 130\right)^{b}, a\left(V_{u}\right)^{b}$, $\mathrm{a}\left(\mathrm{V}_{\mathrm{u}} \cdot \alpha \cdot \mathrm{IS}^{\mathrm{b}}\right.$ e $\mathrm{a}(\mathrm{EIA})^{\mathrm{b}}$. Os resultados obtidos, confirmam a hipótese de que as perdas de solo por erosão são mais bem preditas por um parâmetro erosividade em que esteja incluso em sua composição variáveis combinadas da chuva e da enxurrada, do que parâmetros, que só possuam em sua composição variáveis da chuva tais como o $\mathrm{El}_{30}$.

2. Para locais desprovidos de informações relativas ao volume de enxurrada, os parâmetros erosividade da chuva tais como: $\mathrm{Vrl}_{25}$, $\mathrm{Vrl}_{30}, \mathrm{EWI}_{25}, \mathrm{EWI}_{30} ; \mathrm{El}_{25}$ e $\mathrm{El}_{30}$, podem ser empregados satisfatoriamente como estimadores da erosividade da chuva de Sumé-PB.

3. Os meses de fevereiro, março e abril foram os mais susceptíveis a erosão, visto que neste período ocorreram $79 \%$ das chuvas erosivas. Portanto, medidas eficazes de controle de perdas de terra e água 
devem ser executadas, objetivando evitar que ocorram grandes perdas de terra e água neste período.

4. A susceptibilidade a erosão do solo Bruno Não Cálcico Vértico estimada através do fator $K$ foi considerada baixa $(0,010$ t.ha.h/ha.MJ.mm).

5. O cultivo da palma em nível quando comparado com o cultivo da palma morro abaixo reduziu as perdas de terra pela pela metade. Como o cultivo morro abaixo é uma prática largamente difundida no semi-árido do Nordeste do Brasil, a prática do cultivo em nível pode ser indicada como uma boa alternativa de controle das perdas de terra por erosão.

6. A magnitude das perdas de terra e água por erosão obtidas no presente trabalho, evidenciaram que o desmatamento da vegetação nativa representada pela caatinga pode levar a curto prazo, à degradação acelerada do solo Bruno Não Cálcico, principalmente se forem utilizados sistemas intensivos de cultivo.

7. A vegetação nativa representada pela caatinga por seu eficiente controle das perdas de terra e água, deve ser mantida em áreas com alto risco de perdas de terra e água por erosão.

8. A eficiência da cobertura morta na redução das perdas de terra e água foi semelhante àquela da vegetação nativa, sendo os referidos tratamentos os mais eficientes no controle das perdas de terra e água. Para as condições semi-áridas do Nordeste do Brasil, a cobertura morta em função de sua eficiência no controle das perdas de terra e água, pode ser incluída em sistemas de manejo com faixas de rotações bienais e trienais em que esteja incluso o pousio do solo. 
ANEXO A: Levantamento topográfico das microbacias exprimentais 


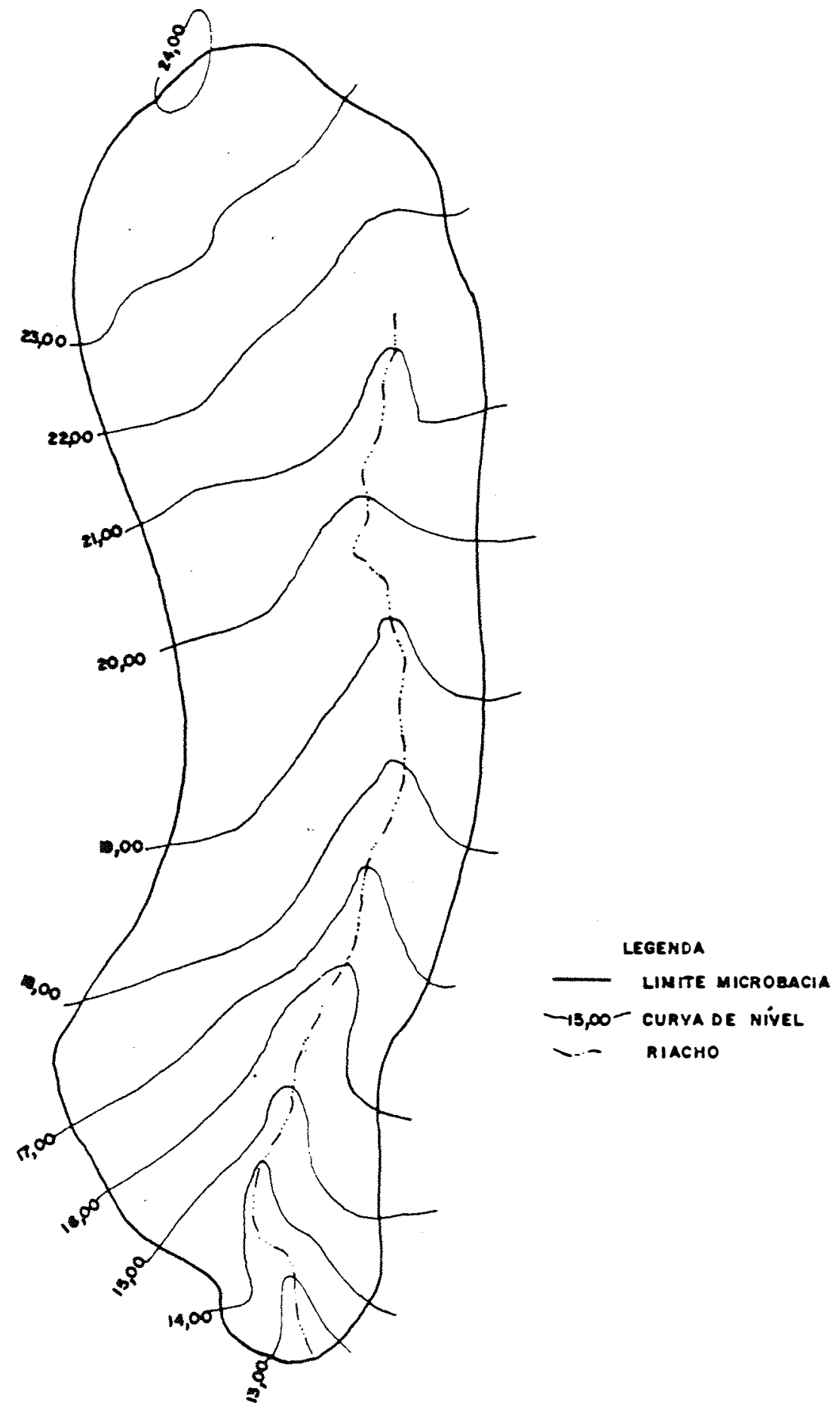

escala

$4 \cdot 12=$

Figura 8. Levantamento topográfico da microbacia $n^{\circ} 1$ (Adaptado de Cadier \& Freitas, 1983) 


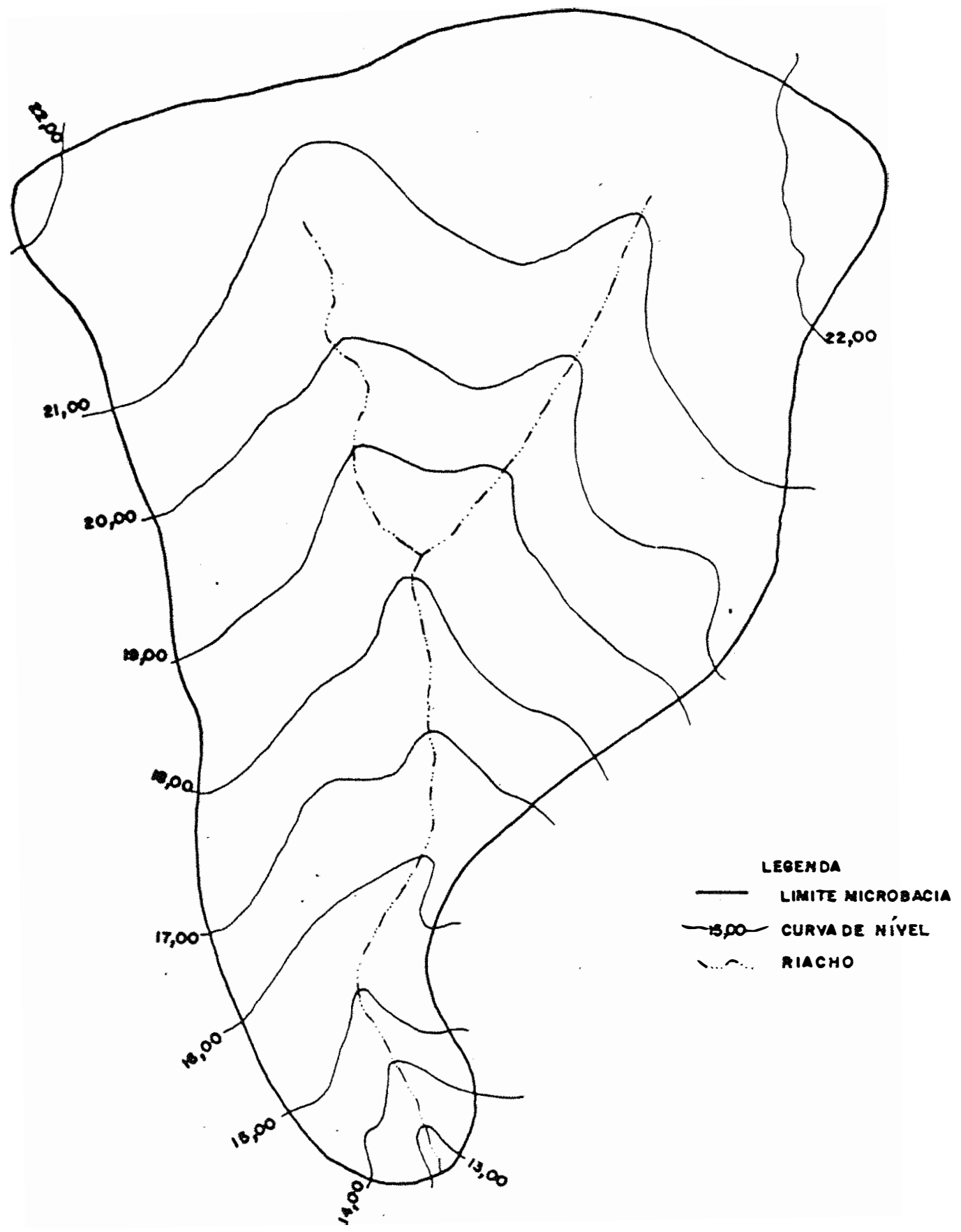

ESCALA

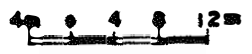

Figura 9. Levantamento topográfico da microbacia $n^{\circ}$ 2. (Adaptado de Cadier \& Freitas, 1983) 


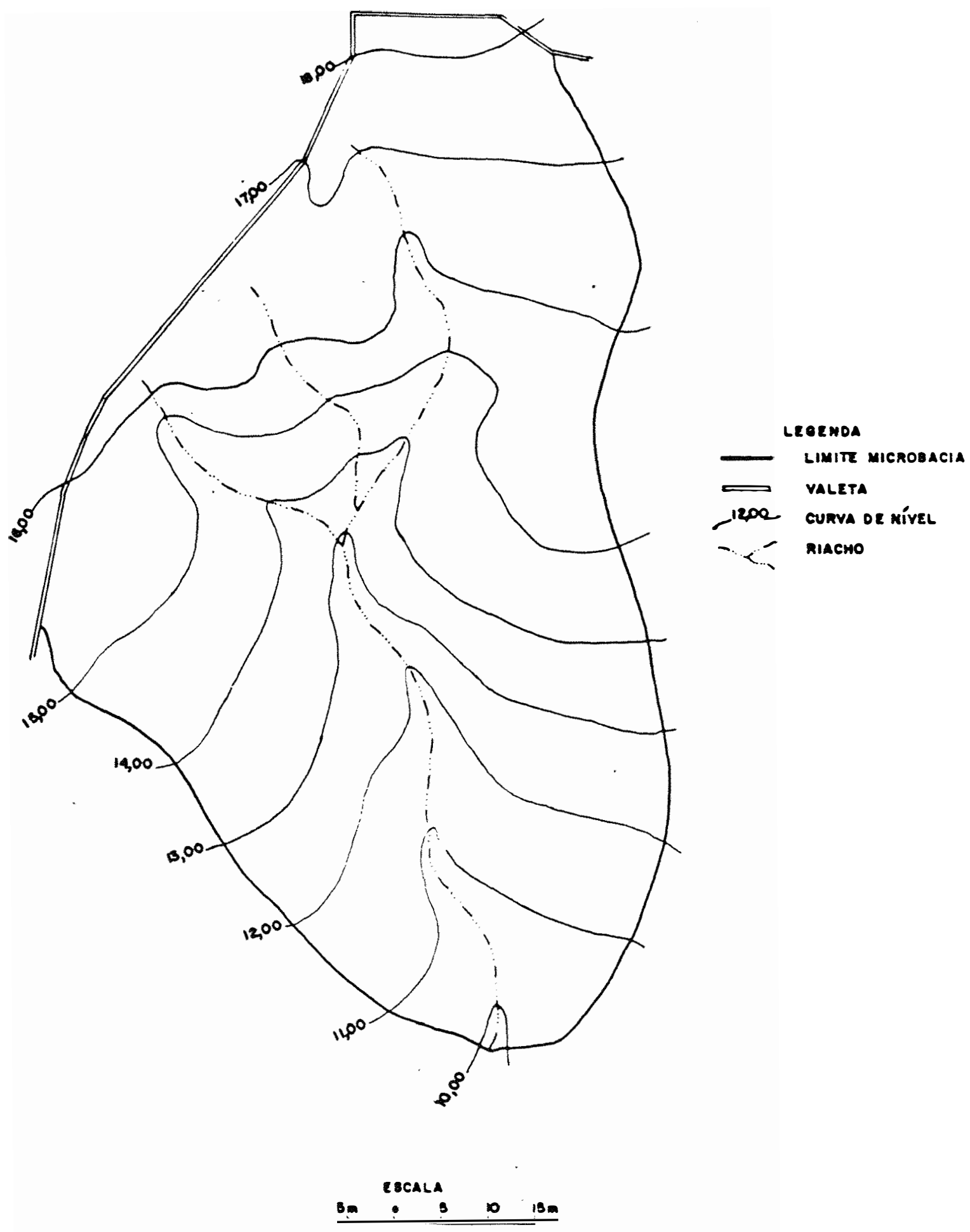

Figura 10. Levantamento topográfico da microbacia $n^{\circ} 3$. (Adaptado de Cadier \& Freitas, 1983) 


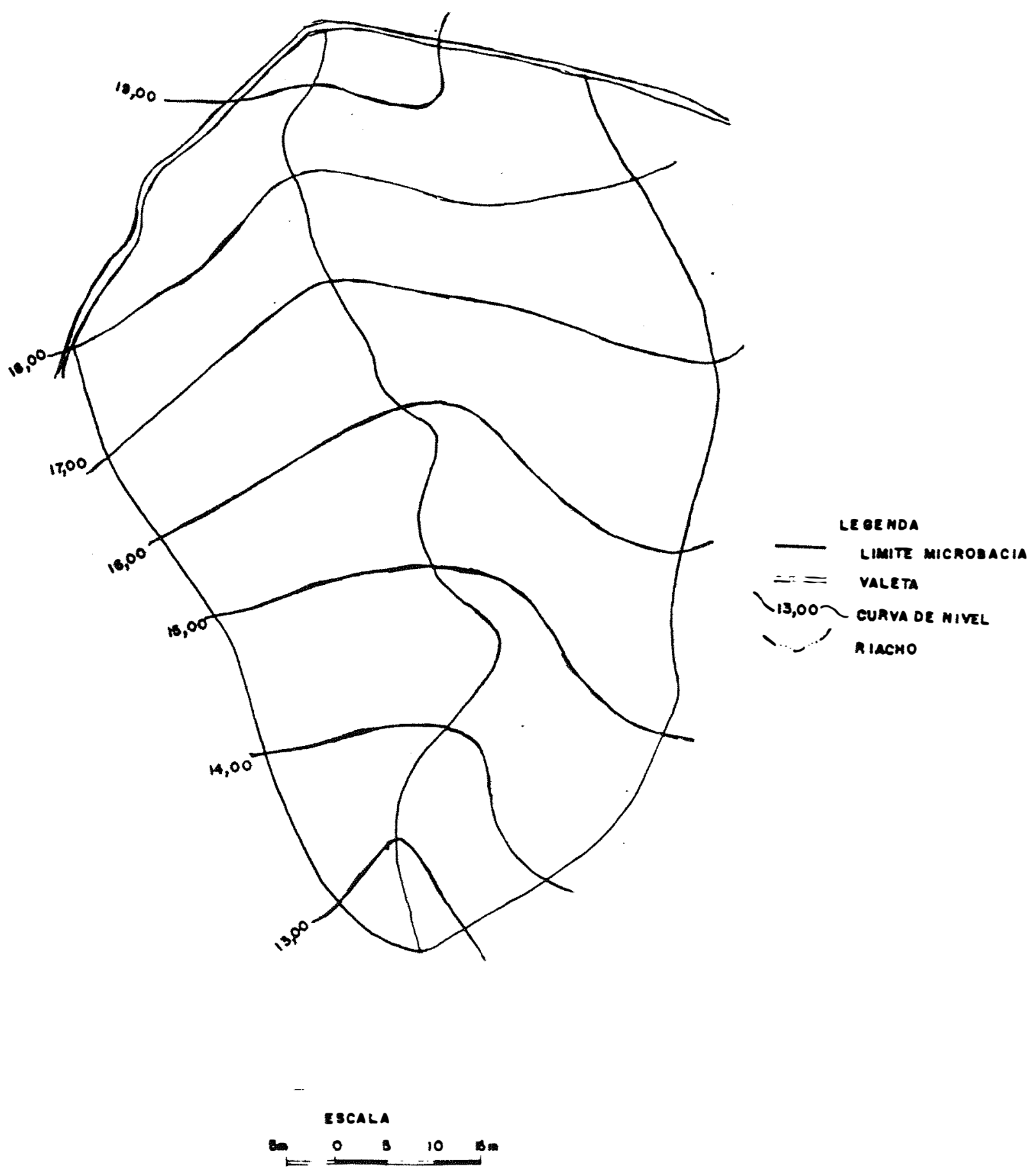

Figura 11. Levantamento topográfico da microbacia $n^{\circ} 4$. (Adaptado de Cadier \& Freitas, 1983) 
ANEXO B: Descrição morfológica,. análise física e química do solo Bruno Não Cálcico Vértico e Mapa das unidades de solo da microbacia de Sumé-PB 
Descrição morfológica do solo Bruno Não Cálcico vértico, A fraco, textura argilosa, caatinga hiperxerófila, onde estão localizados os canteiros coletores de enxurrada:

- Situação e declive: Perfil em terço médio da encosta, com 4\% de declividade.

- Formação geológica e litológica: Pré-Cambriano - Gnaisse.

- Material originário: Saprolito da rocha supracitada.

- Relevo local: Suave ondulado.

- Relevo original: Suave ondulado.

- Drenagem: Moderada a imperfeitamente drenado.

- Pedregosidade: Poucos calhaus na superfície.

- Erosão: Laminar moderada, sulcos superficiais repetidos.

- Vegetação local: Jurema, marmeleiro.

- Vegetação regional: Caatinga hiperxerófila, arbórea-arbustivo.

- Uso atual: Utilizado para pastagens e cultivados com algodão, milho e feijão.

$\mathrm{A}_{1}$ 0-10cm Bruno avermelhado (5YR 4/4), úmido; franco arenosa; fraca média blocos subangulares; muitos poros pequenos; duro, friável, plástico e pegajoso; transição gradual e plana.

IIB2t 10-50cm Bruno avermelhado escuro (5YR 3/3), úmido; francoargilo-arenosa; forte grande prismática, que se desfaz em moderada grande; poucos poros pequenos; extremamente duro, muito firme, muito plástico e muito pegajoso;

IIC Gnaisse semi-intemperizado.

Raizes: $\quad$ Muitas no $A_{1}$ e comuns no llB $2 t$ e IIC.

Observação: Perfil úmido. 


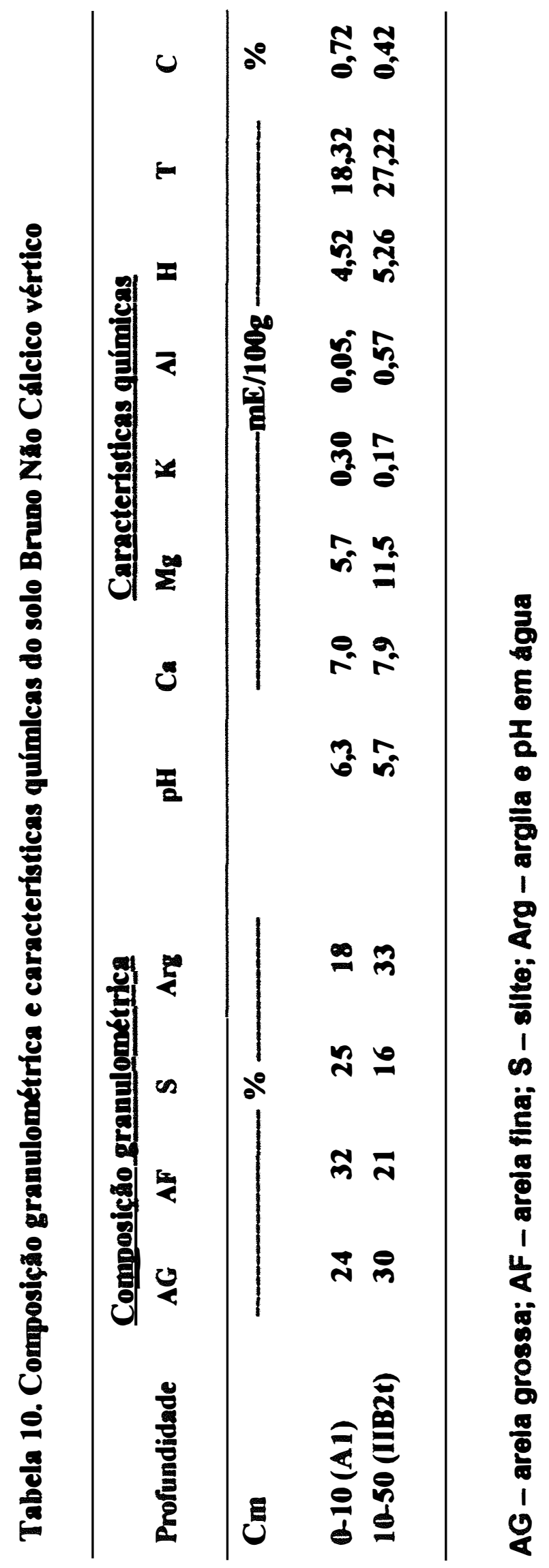




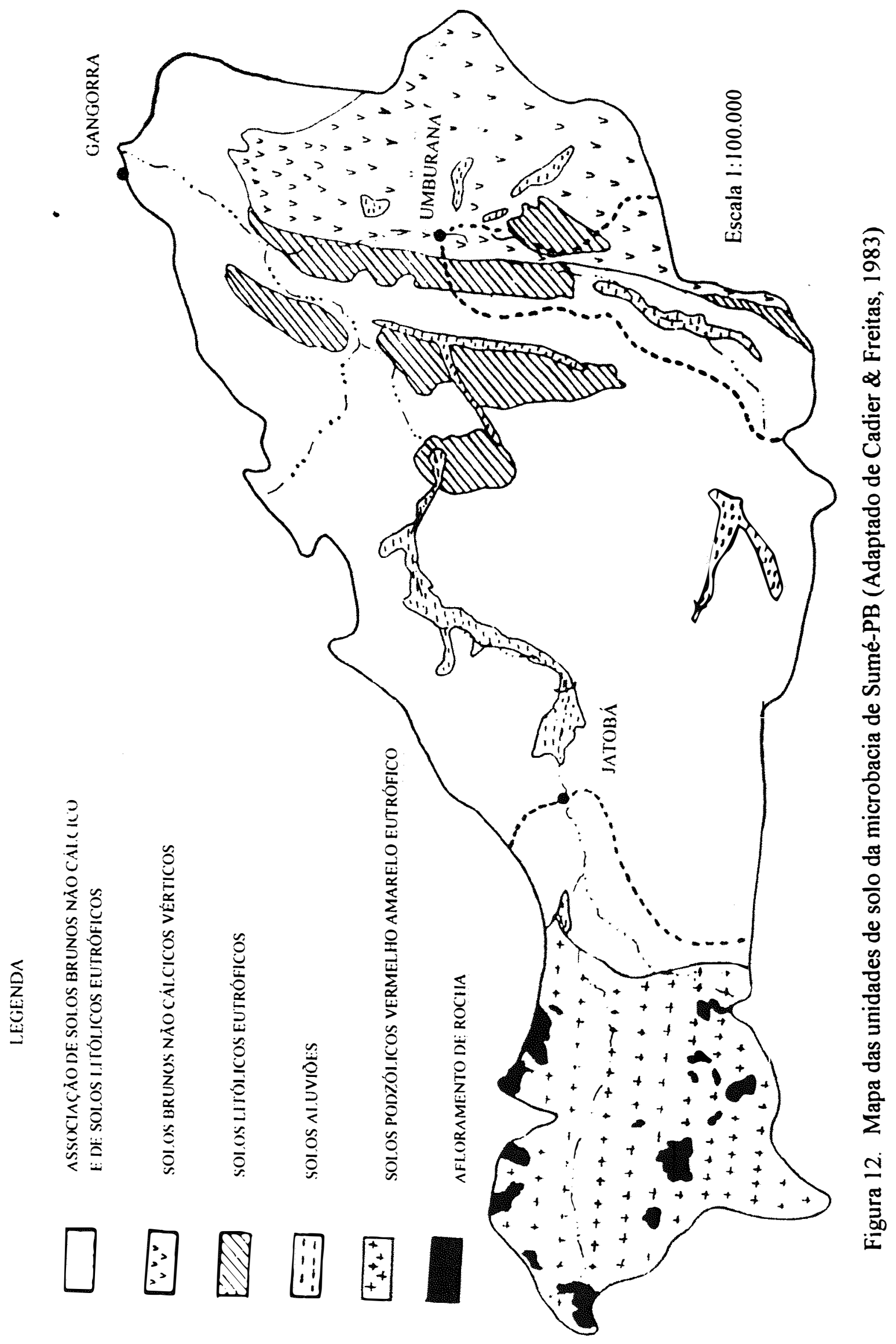


ANEXO C: Valores mensais e médios mensais da precipitação pluviométrica e da erosividade.

Valores médios mensais de perdas de terra e água das parcelas e das microbacias experimentais. 


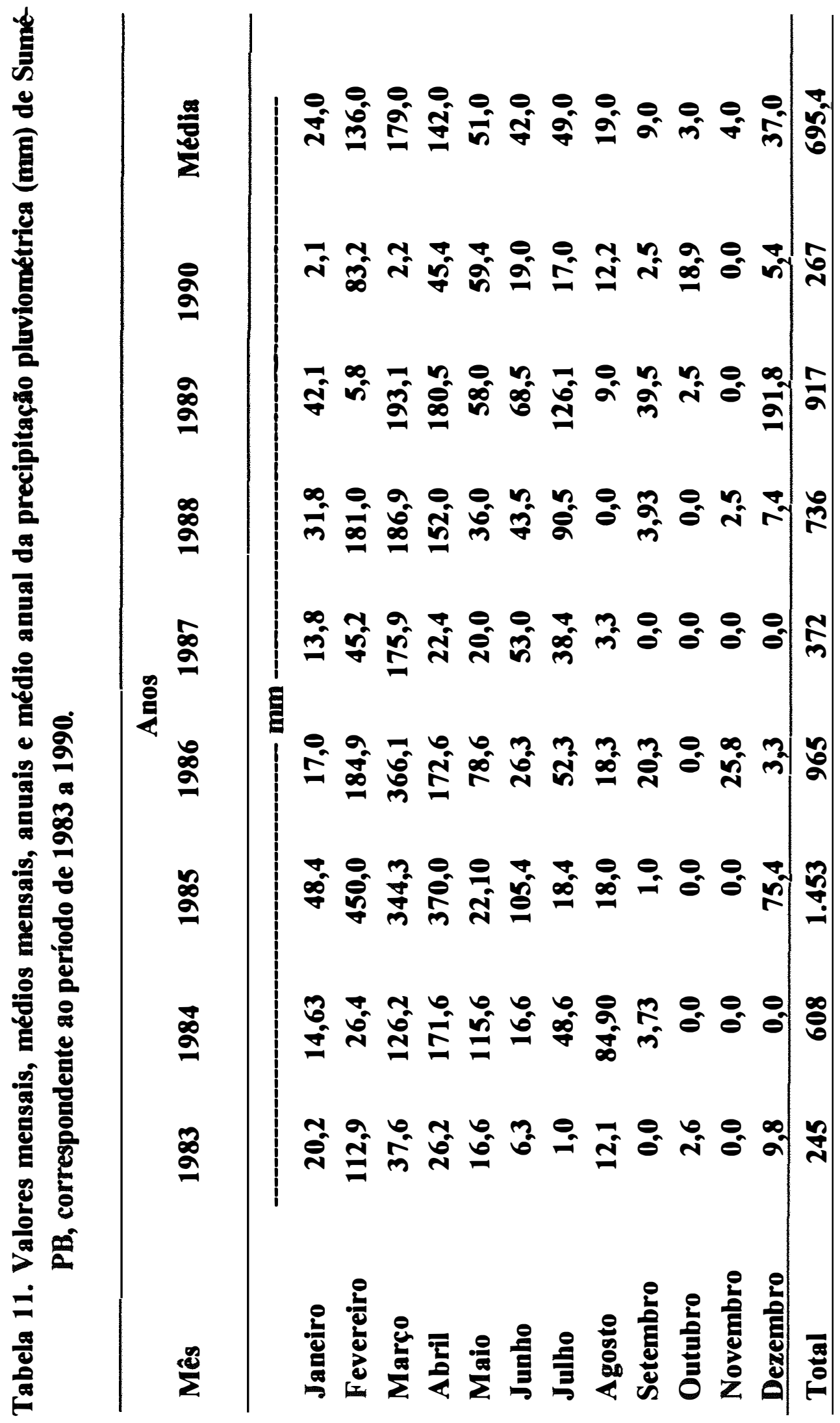




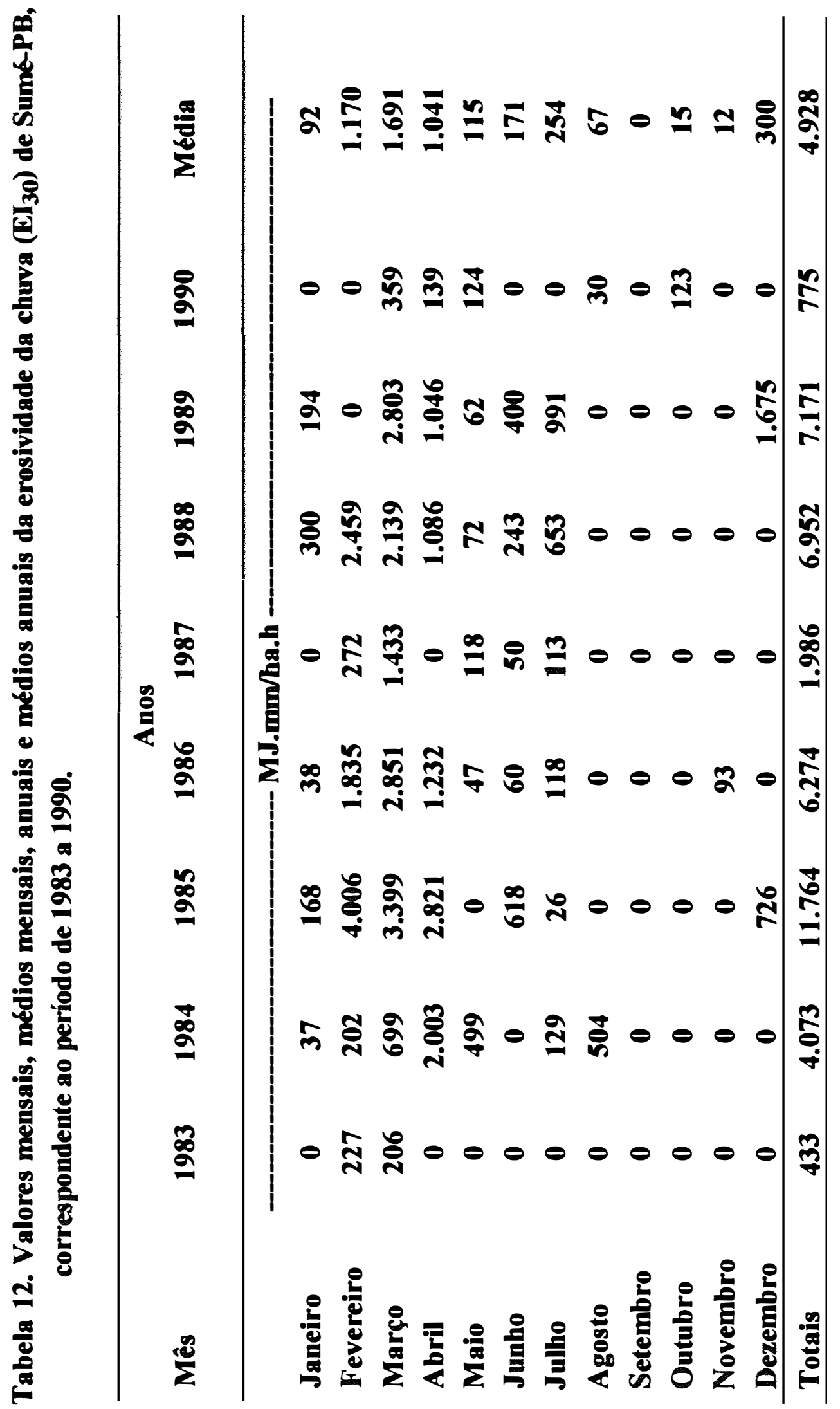




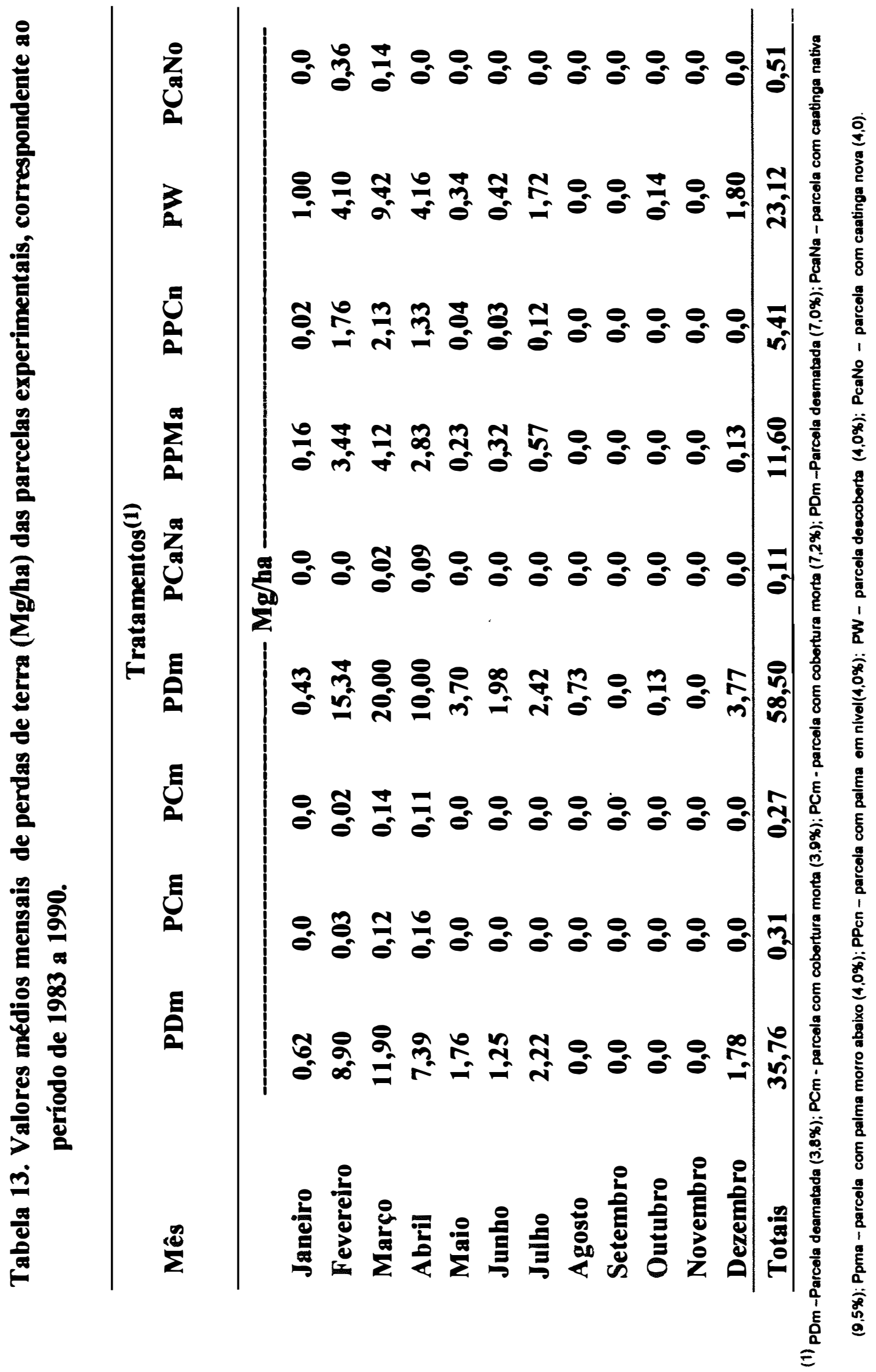




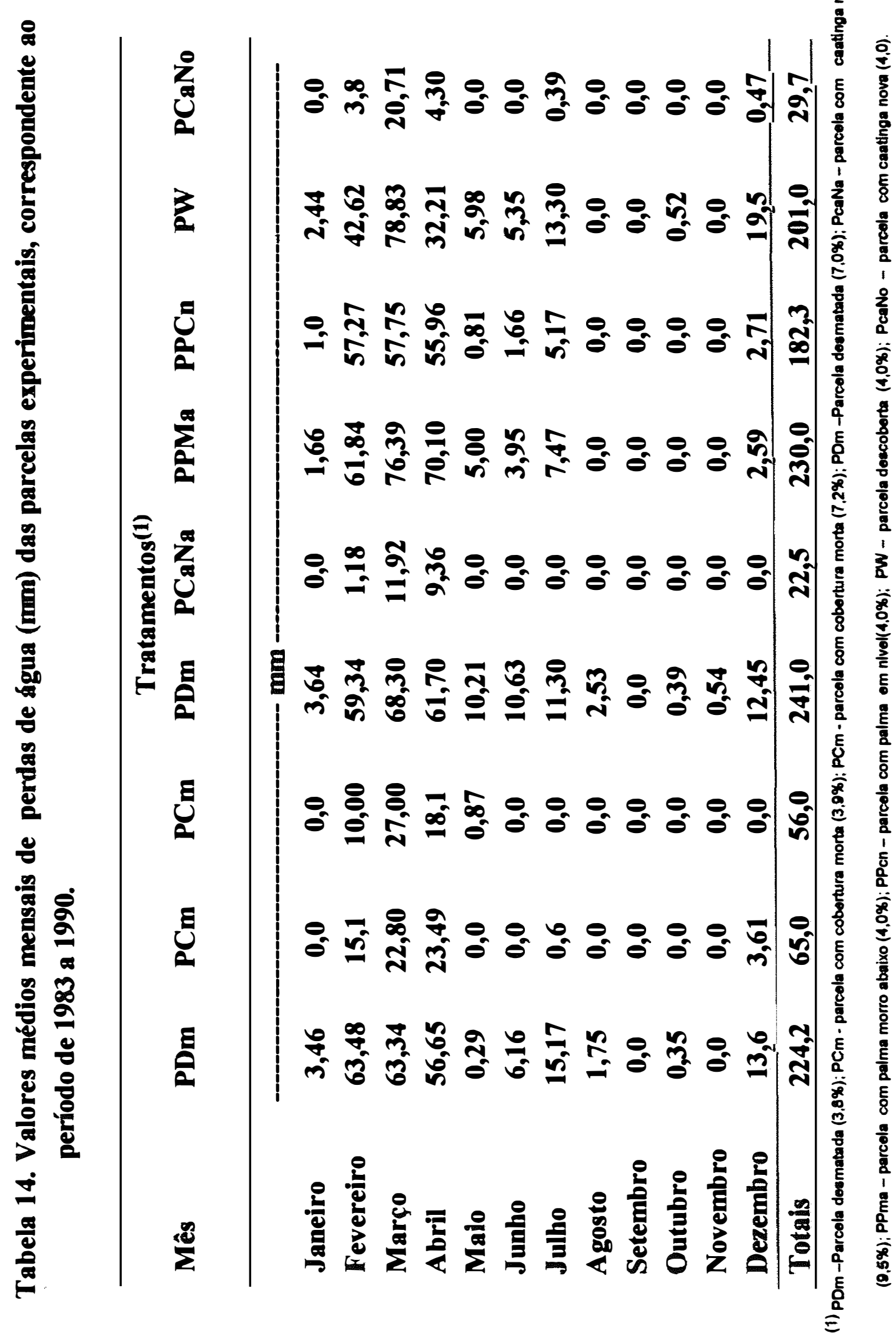




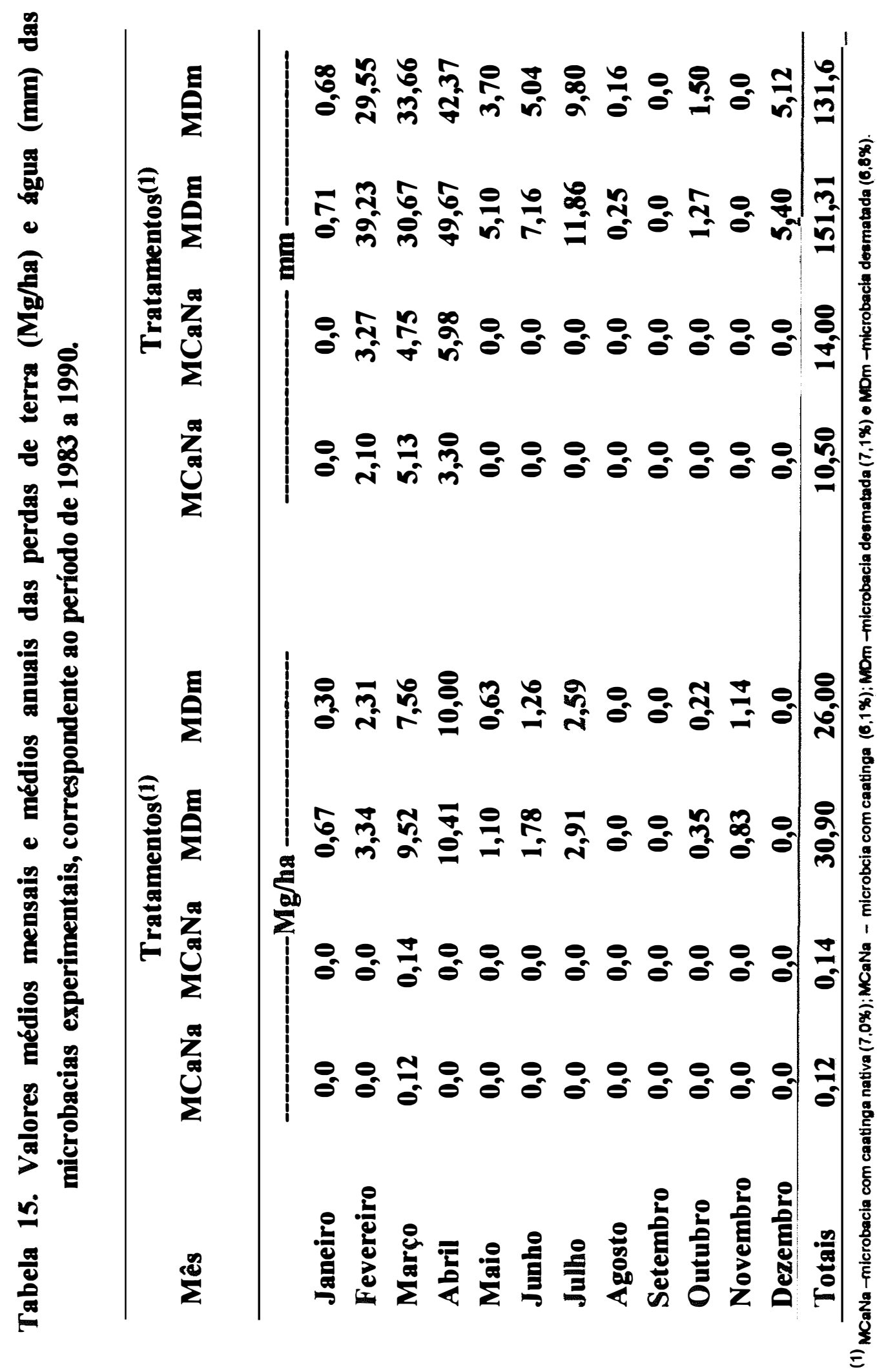




\section{REFERÊNCIAS BIBLIOGRÁFICAS}

ALBERT, E.E.; NEIBLING, W.H. Influence of crop residues on water erosion. In: UNGER, P.W.(Ed.). Managing agricultural residues. Flórida: Lewis Publi, 1994. cap.3, p.19-36.

ALBUQUERQUE, A.W. de. Analysis of the universal soil loss equation aplication in semi-arid norteasterm of Brasil. In: INTERNATIONAL CONFERENCE ON DESERT DEVELOPMENT, 4., México, 1993. Anais. México: IDDC/FAO/ONU, 1993. p. 1157-1167.

ALBUQUERQUE, A.W. de.; CHAVES, I. B.; VASQUES FILHO, J. Características físicas das chuvas correlacionadas com as perdas de solo num regossolo eutrófico de Caruaru-PE. Revista Brasileira de Ciência do Solo, v.18, p.279-283, 1994

AMADO, T.J.C.; COGO, N.P.; LEVIEN, R. Eficácia relativa do manejo do resíduo cultural de soja na redução das perdas de solo por erosão hídrica. Revista Brasileira de Ciência do Solo, v.13, p.251-257, 1989.

ANDRADE, M. C. de. As áreas de domínio de pecuária extensiva e semiintensiva na Bahia e Norte de Minas Gerais. Recife: SUDENE, 1982. p. 259-353. 
ANJOS, J.T.; UBERT, A.A.A.; VIZZOTO, V.J.; LEITE, G.B.; KRIEGER, M. Propriedades físicas em solos sob diferentes sistemas de uso e manejo. Revista Brasileira de Ciência do Solo, v.18, p.139-145, 1994.

ARAÚJO FILHO, J.A; CARVALHO, F.C. Desenvolvimento sustentado da caatinga. In: ALVARES V, V.H.; FONTES, L.E.; FONTES, M.P. (Ed.). O solo nos grandes domínios morfoclimáticos do Brasil e o desenvolvimento sustentado. Viçosa: SBCS/UFV, 1996. p.125-133.

BEN-HUR, M.; SHAINBERG, I.; MORIN, J. Variability of infiltration in a field with surface sealed soil. Soil Science Society American Journal., v.52, p.1299. 1987.

BERTOL, I.; COGO, N.P.; LEVIEN, R. Cobertura morta e métodos de preparo do solo na erosão hídrica em solo com crosta superficial. Revista Brasileira de Ciência do Solo, v.13, p.373-379, 1989.

BERTONI, J.; LOMBARDI NETO, F. Conservação do solo. Piracicaba: Livroceres, 1985. 368p.

CABEDA, M.S.V. Computation of storm El value. West Lafayette: Purdue University, 1976. 6p.

CADIER, E.; FREITAS, B.J. de.; LEPRUN, J.C. Bacia experimental de Sumé: instalação e primeiros resultados. Recife: SUDENE, 1983. 87p. (Série Hidrológica, 16).

CARVALHO, F.L.C.; COGO, N.P.; LEVIEN, R. Eficácia relativa de doses e formas de manejo do resíduo cultural de trigo na redução da erosão hídrica do solo. Revista Brasileira de Ciência do Solo, v.14, p.227-234, 1990. 
CARVALHO, M.P. Fator erosividade da chuva-enxurrada para as chuvas individuais do Estado de São Paulo. Botucatu, 1992. 110p. Tese (Doutorado) - Faculdade de Ciências Agronômicas, Universidade Estadual Paulista.

CARVALHO, M.P.; CATÂNEO, A; LOMBARDI NETO, F. Índices de erosividade da chuva e enxurrada correlacionados com as perdas de solo e determinação da erodibilidade de um latossolo roxo distrófico de Campinas (SP). Revista Brasileira de Ciência do Solo, v.17, p.445-450, 1993.

CARTER, C.E; GREER, J.D; BRAUD, H.J; FLOYD., J.M. Raindrop characterististics in South Central United States. Transaction of the ASAE, v.17, p.1033-1037, 1974.

CATALINCE, J.R.B.; MARGOLIS, E. Características das chuvas e correlação de indices de erosividade com as perdas de solo do Agreste de Pernambuco. Revista Brasileira de Ciência do Solo, v.17, p.275-281, 1994.

CATANEO, A.; CASTRO FILHO, C.; ACQUAROLE, R.M. Programa para cálculo de índices de erosividade de chuvas. Revista Brasileira de Ciência do Solo, v.6, p.236-239, 1982.

DENARDIN, J.E. Erodibilidade do solo estimada por meio de parâmetros físicos e químicos. Piracicaba, 1991. 104p. Tese (Doutorado) - Escola Superior de Agricultura "Luiz de Queiroz", Universidade de São Paulo.

DERPSCH, R.; ROTH, C.H.; SIDIRAS, N.; KOPKE, U. Controle da erosão no Paraná, Brasil. Sistemas de cobertura do solo, plantio direto e preparo conservacionista do solo. Londrina: GTZIAPAR, 1991. 272p. 
DRAGOUN, F.J; MILLER, C.R. Sediment characteristics of two small agricultural watersheds in central Nebrasca. In: SUMMER MEETING OF THE AMERICAN SOCIETY OF AGRICULTURAL ENGINEERS, Fort Collins, 1964. Proceedings. Colorado: American Society of Agricultural Engineers, 1964 , p.19.

FAO. Desarrollo sostenible de tierras aridas y lucha contra la desertificacion: Posición de la FAO. Rome, 1993a. 30p.

FAO. Key aspects of strategies for the sustainable development of drylands. Rome, 1993b. 60p.

FOSTER, G.R; MEYER, L.D. Mathematical simulation of upland erosion by fundamental erosion mechanics. In: PRESENT AND PROSPECTIVE TECHNOLOGY FOR PREDICTING SEDIMENT YIELD AND SOURCES, 1. Oxford, 1972. Proceedings. Oxoford: UDSA, Agricultural Research Service, 1975. p.190-207.

FOSTER, G.R.; LOMBARDI NETO, F; MOLDENHAUER, W.C. Evaluation of rainfall-runoff erosivity factores for individual storms. Transactions of de ASAE, v.25, p.124-129, 1982.

FOSTER, G.R., MEYER, L.D; ONSTAD, C.A. An erosion equation derived from basic erosion principles. Transactions of the ASAE, v.20, n.4, p.678-682, 1977a.

FOSTER, G.R.; MEYER, L.D.; ONSTAD, C.A. A runoff erosivity factor and variable slope length expoents for soil loss estimates. Transactions of the ASAE, v.20, n.4, p.683-687, 1977b. 
FOSTER, G.R.; McCOOL, D.K.; RENARD, K.G.; MOLDENHAUER, W.C. Conservation of the Universal Soil Loss Equation the SI metric units. Journal of Soil and Water Conservation, v.36, p.355-359, 1981.

FREITAS, M.B; CHOUDHURY, E.N; FARIA, C.M.B. Manejo e conservação de solo no agreste pernambucano. Petrolina: EMBRAPA, CPATSA, 1981. 44p. (EMBRAPA. CPATSA. Boletin técnico 6).

GALINDO, I.C.; MARGOLIS, E. Tolerância de perdas de solos do Estado de Pernambuco. Revista Brasileira de Ciência do Solo, v.13, p.95-100, 1989.

GALVÃO, C. O. Modelagem do escoamento superficial e da erosão do solo em microbacias. Campina Grande, 1990. 185p. Dissertação (Mestrado) Universidade Federal da Paraiba.

GRAYBILL, F.A. An introdution to linear statistical model. New York: McGrawHill, 1961. 684p.

HUDSON, N.W. Soil conservation. 2.ed. Ithaca: Cornell University Press, 1981. 324p.

LAL, R. Soil erosion on Alfisol in Western Nigéria, III. Effects of rainfall characteristics. Geoderma, v.16, p.389-401, 1976.

LAWS, J.O; PARSONS, D.A. The relation of raindrop size to intensity. American Geophysical Union Transctions, v.24, p.452-459, 1943

LEPRUN, J.C. Manejo e conservação de solos do Nordeste. Recife: SUDENE, 1988. 238p.

LEVIEN, R.; COGO, N.P.; ROCKENBACH, C.A. Erosão na cultura do milho em diferentes sistemas de cultivo anterior e métodos de preparo do solo. Revista Brasileira de Ciência do Solo, v.14, p.73-80, 1990. 
LOMBARDI NETO, F. Universal soil loss equation (USLE), runoff erosivity factor, slope length expoent, and slope steepness expoent for individual storms. West Lafayette, 1979. 128p. Thesis(Phd) - Purdue University.

LOPES, P.R.C.; N.P. COGO,, N.P.; LEVIEN, R. Eficácia relativa de tipo e quantidade de resíduos culturais espalhados uniformente sobre o solo na redução da erosão hídrica. Revista Brasileira de Ciência do Solo, v.11, p.271-275, 1987.

MARGOLIS, E; CAMPO FILHO, O.R. Determinação dos fatores da equação universal de perda de solo num podzólico vermelho-amarelo de Glória do Goitá-PE. In: ENCONTRO NACIONAL DE PESQUISA SOBRE CONSERVAÇÃO DO SOLO, 3., Recife, 1980. Recife: Sociedade Brasileira de Ciência do Solo, 1981. p.239-250.

MARGOLIS, E.; GALINDO, I.C. de L.; MELLO NETTO, A.V. de. Comportamento de sistemas de cultivo da mandioca em relação à produção e às perdas por erosão. Revista Brasileira de Ciência do Solo, v.15, p.357-362, 1991.

MARGOLIS, E.; SILVA, A.B. da.; JACQUES, F. de O. Determinação dos fatores da equação universal de perda de solo para as condiçoes de Caruaru-PE. Revista Brasileira de Ciência do Solo, v.9, p.165-169, 1985.

MELO, M. L. Áreas de exceção da Paraiba e dos sertões de Pernambuco. Recife: SUDENE, 1988. 321p. (SUDENE. Estudos Regionais, 19).

MELO FILHO, J.F.; SILVA, J.R.C. Erosão, teor de água no solo e produtividade do milho em plantio direto e preparo convencional de um podzólico vermelho-amarelo no Ceará. Revista Brasileira de Ciência do Solo, v.17, p.291-297, 1993. 
MENDES, B.V. Desertificação do semi-árido. In: SEMINÁRIO SOBRE DESERTIFICAÇÃO NO NORDESTE, Recife, 1986. Trabalhos apresentados. Brasilia: Ministério do Desenvolvimento Urbano e do Meio Ambiente e Secretaria Especial do Meio Ambiente (SEMA), 1986. p.111115.

MEYER, L.D; WISCHMEIER, W.H. Mathematical simulation of the process of soil erosion by water. Transactions of the ASAE, v.12, n.6, p.754-758,762, 1969.

MEYER, L.D.; FOSTER, G.R.; ROMKENS, M.J.M. Source of soil eroded by water from upland slopes. In: PRESENT AND PROSPECTIVE TECNOLOGY FOR PREDICTING SEDIMENT YIELDS AND SOURCES, 1., Oxoford, 1972. Proceedings. Oxford: USA, Research Service, 1975. p.177-189.

MOLINIER, M.; AUDRY, P.; DESCONNETES, J.C.; LEPRUN, J.C. Dinâmica da água e das matérias em um ecossistema representativa do Nordeste brasileiro. Condições de extrapolação espacial na escala regional. Recife: SUDENE, 1989. 27p.

MORAIS, L.F.B. Índices de erosividade de chuvas naturais correlacionadas com perdas de solo em três locais do Rio Grande do Sul. Santa Maria, 1986. 108p. Dissertação (Mestrado) - Universidade Federal de Santa Maria.

NEARING, M.A.; LANE, L.J.; ALBERTS, E.E.; LAFLEN, J.M. Prediction technology for soil erosion by water: status and research needs. Soil Science Society American Journal. v.54, p.1702-1711, 1990.

OWOPUTI, L.O.; STOLTE, W.J. Soil detachment in the physically based soil erosion processes: A review. Transctions of the ASAE, v.38, n.4, p.10991110, 1995. 
RAMOS, A.D.; MARINHO, H.E. Estudo da erodibilidade de um solo litólico sem cobertura vegetal e sob duas condições de pastagens nativa de caatinga. Sobral: EMBRAPA, 1981. 16p. (EMBRAPA. Boletim de Pesquisa, 2).

REIS, J.G. Desertificação no Nordeste. Recife: SUDENE, 1988. 40 p.

REICHERT, J.M.; CABEDA, M.S.V. Salpico de partículas e selamento superficial em solos do Rio Grande do Sul. Revista Brasileira de Ciência do Solo, v.16, p.389-396, 1992.

ROTH, C.H.; HENKLAIN, J.C.; FARIAS, G.S. de. Avaliação preliminar do tamanho de gotas de chuva natural, dos simuladores de Swanson e Goettingen para o Norte do Paraná. In: ENCONTRO NACIONAL DE PESQUISA SOBRE CONSERVAÇÃO DO SOLO, 5., Porto Alegre, 1984. Resumos. Campinas: Sociedade Brasileira de Ciência do Solo, 1984. p.71.

SAS INSTITUTE. SAS/STAT: guide for personal computers, version 6 Edition. Cary, 1988. 378p.

SEMINÁRIO SOBRE DESERTIFICAÇÃO NO NORDESTE, Brasilia, 1986. Trabalhos apresentados. Brasilia: Ministério do Desenvolvimento Urbano e Meio Ambiente, Secretaria Especial do Meio Ambiente, 1986. 215p.

SILVA, I.de F. da; ANDRADE, A.P; CAMPOS FILHO, O.R. Erodibilidade de seis solos do semi-árido paraibano obtida com chuva simulada e método nomográfico. Revista Brasileira de Ciência do Solo, v.10, p.283-287, 1986. 
SILVA, I.de F. da; CAMPOS FILHO, O.R; ANDRADE, A.P. de; COÊLHO, E.A.C; DINIZ, E.J. Influência do cultivo isolado e do consórcio sobre as perdas de solo e água numa terra roxa estruturada. Revista Brasileira de Ciência do Solo, v.13, p.111-115, 1989.

SINGER, M.J.; MATSUDA, Y.; BLACKARD, J. Effect of mulch rate on soil loss by raindrop splash. Soil Science Society American Journal,. v.45, p.107110, 1981.

SOUSA, A.R.; NUNES FILHO, A.B.; SILVA, A.B.; MAFRA, R.C. Efeito da cobertura vegetal em relação a erosão num solo Bruno Não Cálcico de Serra Talhada-PE. In: CONGRESSO BRASILEIRO DE CIÊNCIA DO SOLO, 24., Goiânia, 1993. Resumos. Goiânia: Sociedade Brasileira de Ciência do Solo, 1993. p.169-170.

STEINER, J.L. Crop residue effects on water conservation. In: UNGER, P.W.(Ed.) Managing agricultural residues. Flórida: Lewis Publi. 1994. cap.4, p.42-70

SUDENE. Ecossistemas e potencialidades dos recursos naturais do Nordeste. Recife, 1989. p.24-42.

VASCONCELOS SOBRINHO, J. Metodologia para identificação de processos de desertificação. Manual de indicadores. Recife: SUDENE, 1971. 21p.

VASCONCELOS SOBRINHO, J. O deserto brasileiro: Projeto do trópico árido. Recife: Univ. Fed. de Pernambuco, 1974. 24p.

VASCONCELOS SOBRINHO, J. Desertificação do Nordeste brasileiro. Recife: Univ. Fed. de Pernambuco, 1983. 21p. 
WAGNER, C.S.; MASSAMBANI, O. Análise da relação intensidade de chuvaenergia cinética de Wischmeier \& Smith e sua aplicabilidade à região de São Paulo. Revista Brasileira de Ciência do Solo, v.12, p.197-203, 1988.

WILLIAMS J.R. Sediment-Yield Prediction With Universal Equation Using Runoff Energy Factor. In PRESENT AND PROSPECTIVE TECHONOLOGY FOR PREDICTING SEDIMENT YIELD AND SOURCES. Washingthon: USDA, Agricultura Research Service, 1975. p. 244-252.

WILLIAMS, J.R.; HILER, E.A.; BAIRD, R.W. Prediction of sediment yields from small watersheds. Transactions of the ASAE, v.14, n.6, p.1158-1162, 1971.

WILLIAMS, J.R.; BERNDT, H.D. Sediment yield prediction based on watershed hydrology. Transactions of the ASAE, v.20, p.1100-1104, 1977.

WISCHMEIER, W.H.; SMITH, D.D. rainfall energy and its relationschip to soil loss. Transaction American Geophysical Union, v.39, p.285-291, 1958.

WISCHMEIER, W.H.; SMITH, D.D. Predicting rainfall erosion losses: a guide to conservation planning. Washington: USDA, 1978. 58p. (USDA. Agricultural Handbook, 537). 